Западно-Казахстанский инновационнотехнологический университет

\title{
Методика \\ физического воспитания учащихся \\ в специальных школах
}

Уральск, 2021 
Западно-Казахстанский инновационнотехнологический университет

Авторы-составители: Пересветов Н.Н., Кузнецова А.Н. Литературный редактор: Кузнецова А.Н.

\section{Рецензенты:}

Адильбаева Н.А., кандидат педагогических, доктор исторических наук, заведующая кафедрой педагогики и психологии, профессор Западно-Казахстанского государственного университета им. М. Утемисова.

Коломоец Н.К., кандидат педагогический наук, доцент кафедры физического воспитания Западно-Казахстанского государственного аграрно-технологического университета им. Жангир хана.

M 54 Методика физического воспитания учащихся в специальных школах: Учебное пособие для студентов и магистрантов педвузов, университетов. / Сост. Н.Н.Пересветов, А.Н.Кузнецова. - Уральск: «Полиграфсервис», 2021. - с.

\section{УДК 371.3}

ББК 74.267 .5

ISBN 978-601-7424-24-4

(C) Сост. Пересветов Н.Н., Кузнецова А.Н., 2021

\section{Лекционное занятие 1-ое.}

Краткая история возникновения и развития ЛФК, как специальной отрасли знания

\section{Лекционное занятие 2-ое.}

Адаптивная физическая культура в практике работы по физическому воспитанию современной специальной общеобразовательной школы.

\section{Лекционное занятие 3-ье.}

Методы научного исследования наиболее часто применяемые в специальных школах, физкультурно-спортивном,

туристическом краеведении.

\section{Лекционное занятие 4-ое.}

Инновационная деятельность воспитателей, учителей физической культуры казахстанского Приуралья.

Лекционное занятие 5-ое.

Образовательно-воспитательная работа с детьми и подростками, имеющими отклонения в интеллектуальном

развитии.

\section{Лекционное занятие 6-ое.}

Массаж при детских церебральных параличах достижения практики ЛФК

Лекционное занятие 7-ое.

Современное ЛФК в действии. Значение ЛФК в профессиональной подготовке специалистов ФКиС 


\section{Лекционное занятие 8-ое.}

Восточно-оздоровительные системы и нетрадиционные формы физического воспитания в Казахстане: история и

современность

\section{Лекционное занятие 9-ое.}

Особенности физического воспитания учащихся

отнесенных к специальной медицинской группе.

\section{Лекционное занятие 10-ое.}

Формирование правильной осанки учащихся средствами ФКиС. Из опыта учителя СШ №24 г. Уральска,

А.А. Сорокиной

\section{Лекционное занятие 11-ая}

Особенности учебно-воспитательной работы со

слабослышащими, позднооглохшими

детьми дошкольного возраста..

\section{Лекционное занятие 12-ое}

Девиантное поведение детей и подростков

как психолого-педагогическая проблема.

Особенности физического воспитания детей

с девиантным поведением.

\section{Лекционное занятие 13-ое.}

Физическое воспитание в специальных школах при

заболеваниях сердечно-сосудистой системы (ССС)

\section{Лекционное занятие 14-ое.}

Создание необходимых условий для самостоятельных занятий учащихся физическими упражнениями дома, по месту жительства. Самомассаж при занятиях спортом высоких достижений
Лекционное занятие 15-ое.

Гимнастические комплексы на дачных участках и их роль в активизации физической подготовки детей с отставанием в умственном развитии.

\section{Лекционное занятие 16-ое.}

Спортивно-педагогические, научные кадры

Западного Казахстана: от постановки проблемы

к ее решению.

СЕМИНАРСКИЕ ЗАНЯТИЯ

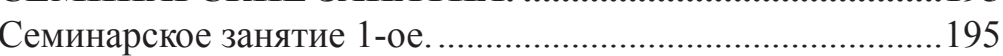

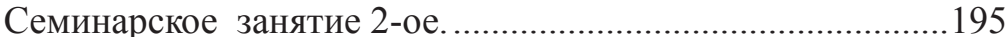

Семинарское занятие 3-е................................................196

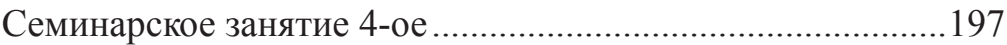

Семинарское занятие 5- ое................................................199

Семинарское занятие 6 - ое..................................................199

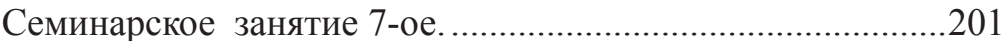

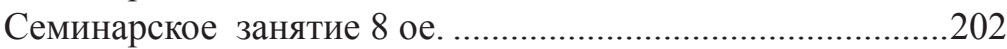

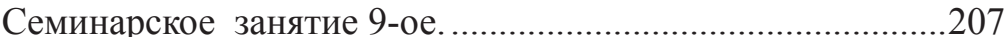

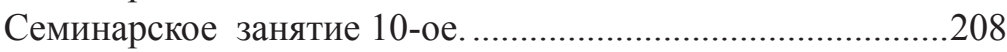

Семинарское занятие 11-ое...........................................209

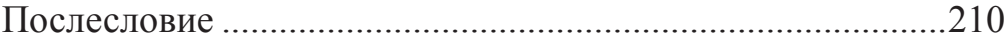

Список использованной и рекомендуемой литературы ......220 


\section{ЛЕКМКОННЫЕ ЗАНЯТКЯ}

\section{Лекционное занятие I-ое.}

Тема: Краткая история возникновения и развития ЛФК, как специальной отрасли знания.

\section{План}

1. Лечебная физическая культура в государствах Древнего Востока, Древней Греции и Рима;

2. Современная ЛФК в действии;

3. Значение ЛФК в профессиональной подготовке пециалистов ФКиС.

4. Некоторые практические рекомендции для практиКИ

\section{Литература:}

1. Власова Т.А. и др. О детях с отклонениями в развитии. 2-е издание исправлендации . и дополн. - М., Просвещение, 1973;

2. Никуленко Т.Г. и др. Коррекционная педагогика. 2-ое издание. - Ростов н/д, Феникс, 2009;

3. Теория и практика физической культуры. Лекции, - СПб, 1999; Жищенко А.Н. Коррекционные и развивающие уражнения для детей с нарушением интеллектуального развития. Метдические рекомендации. - Уральч, 2009, стр. 68.

Цель данного раздела учебно-методического пособия - раскрыть содержани понятий: «Лечебная физическая культура» (ЛФК) и ее роль в совершенствовании процесса профессиональной подготовки специалстов занятых в области физической культуры и спорта. На этом фоне предполагается дать определения и раскрыть понятия: «Специальная школа» - школа для детей с ограниченными возможностями (глухих, слепых, умственно отсталых и т.п. Особое внимани обращено на понятие «Девиантность», «Девиантное поведение» детей и подростков». При этом подчеркивалось, что «Девиантность» - это устойчивое поведение личности отклоняющееся от общепринятых норм. Девиантность как общественное явление изучается социологией, педагогикой и психологией и другими и отраслями научного знания. В наши дни есть масса примеров, когда негативная девиантность подростков исправляется под действием традиций и правил соревнований сложившихся в спорте, особенно, спорте высоких достижений.

В наши дни девиантность делится на на положительную и негативную. К негативной девиантности относят:

- уголовные преступления;

- алкоголизм;

- наркоманию;

- азартные игры;

- проституцию;

- экстримизм;

- терроризм;

- вандализм;

- самоубийства;

- жадность.

К положительным видам девиации относятся:

- самопожертвование;

- героизм;

- обостренное чувство жалости;

- гениальность;

- выдающиеся умственные способности. 
Анализ литературных источников позволяет утверждать, что физические упражнения достаточно давно использоваются не только как средства воспитания, но и оздоровления и лечения от различных недугов. Так, например, еще в Древней Индии, Египте и Китае при тугоподвижности в суставах применялись вытягивания и водные процедуры, массаж, лечебная гимнастика.

В Древнем Китае, например, насчитывалось более 800 различных упражнений связанных с лечением органов дыхания. В профилактических целях упражнения широко применялись связанные с задержкой ДЫХАНИЯ. Врачи древности широко рекомендовали своим пациентам гидропроцедуры в сочетании с гигиеной питания.

Арабский ученый и естествоиспытатель Абу-Али ибн Сина (Авиценна) в свих научных трактатах: «Книга исцеления» и «Канон врачевания» подробно описывает содержание лечебной гимнастики, банные, массажные процедуры по уходу за телом, особенно, с профилактической целью.

В полный курс лекций, семинарских и ЛПЗ, по нашему мнению должны входить темы:

1. Краткая история возникновения и развития ЛФК, как специальной отрасли знания.

2. ЛФК, как отрасль необходимого человеческого знания и образования учащихся с ограниченными возможностями. Физическое воспитание в специальных школах.

3. Методы научного исследования наиболее часто применяемые в физкультурно-спортивном, краеведческом поиске.

4. Инновационная деятельность воспитателей, учителей физической культуры казахстанского Приуралья.
5. Образовательная работа с умственно отсталыми детьми и подростками.

6. Массаж при детских церебральных параличах - достижения передовой педагогической практики.

7. Современная ЛФК в действии. Значене ЛФК в профессиональной подготовке специалистов ФКиС.

8. Восточные оздоровительные системы и нетрадиционное физическое воспитание в Казахстане: история и современность.

9. Формирование правильной осанки учащихся средствами ФКиС. Из опыта учителя СОШ №24г.Уральска А.А. Сорокиной.

10. Особенности физического воспитаня детей и подростков отнесенных к специальной медицинской группе.

11. Девиантное поведение детей и подростков как психолого-педагогическая проблема. Особенности физического воспитания учащихся с девиантным поведением.

12. Физическое воспитание при заболеваниях сердечно-сосудистой системыы (ССС).

13. Физическое воспитание при заболеваниях дыхательной системыьы (ДС).

14. Создание необходимых условий для самостоятельных занятий учащихся физическими упражнениями дома, по месту жительства. Самомассаж при занятиях спортом высоких достижений.

15. Использование различных типов спортивного массажа, как средства профилактики и лечения заболеваний.

16. Японский массаж (иатсу) и особенности его применения в практической деятельности специалистов по 
ЛФК.

2. Индийский массаж и другие средства двигательной деятельности при различных заболеваниях.

3. Массаж льдом (криомассаж) в практической деятельности специалистов ЛФК.

4. Точечный и др. типы массажа реабилитации при гиподинамии и особенности подбора эффективных средств спортивного массажа.

5. Общий массаж при экстримальных нагрузках в спорте.

6. ЛФК при заболеваниях ССС.

7. ЛФК призаболеваниях дыхательной системы.

Проведенная нами условная группировка тем представленных в пособии дают возможность утверждать, что они могут быть представлены в виде пятиконечной звезды, где есть место темам широко используемым учителями школ, спортивными тренерами, организаторами физической культуры по месту жительства школьников, учащихся определенных в специальные медицинские группы и т.п (см. рис.1.)
Взаимосвязь тем и разделов, представленных в учебно-методическом пособии - «Физическая культура в специальных школах». - Уральск, 2020.

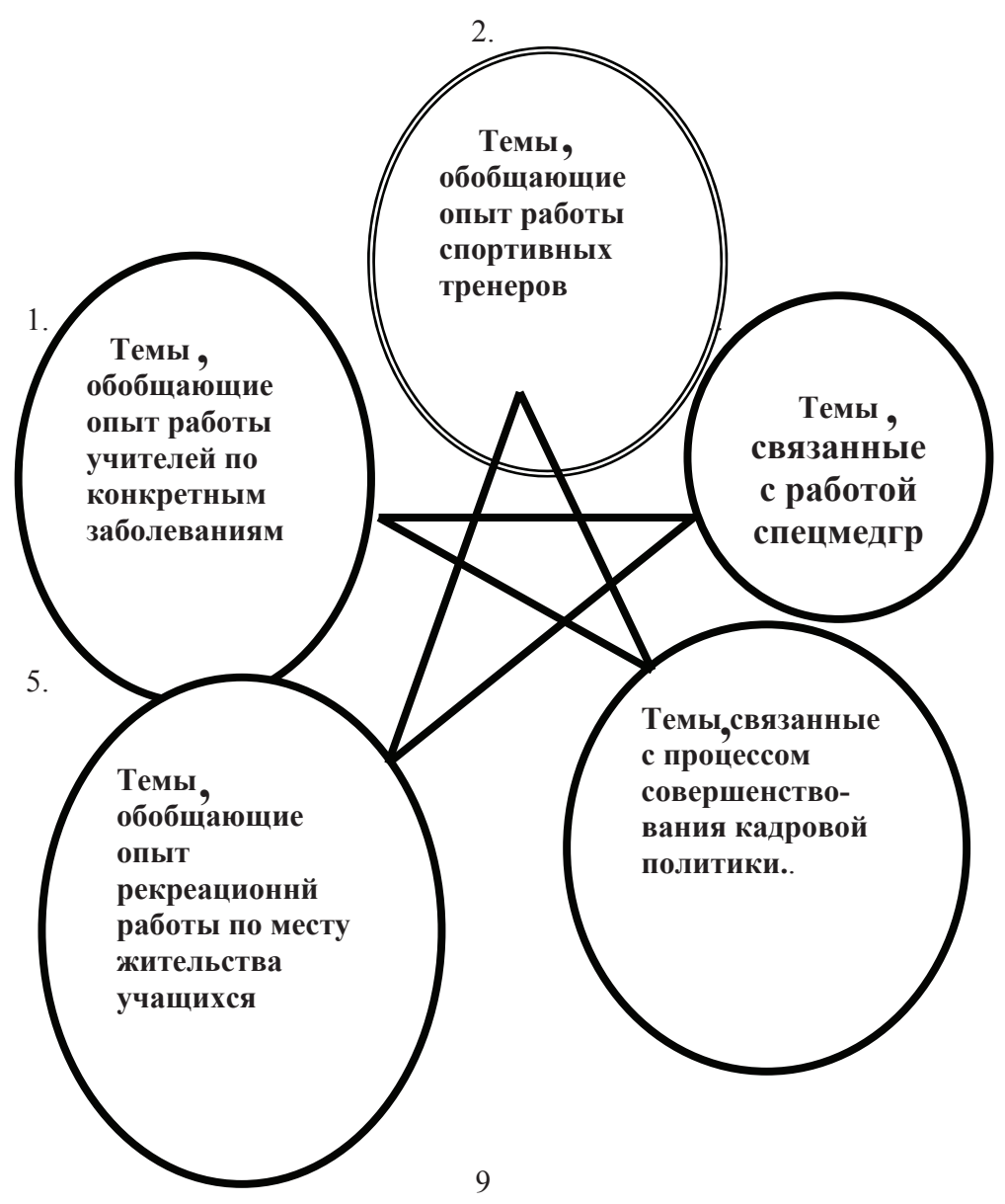

Рис. 1. 


\section{Лекционное занятие 2-ое.}

Тема: Адаптивная физическая культура в практике работы по физическому воспитанию современной СПЕЦИАЛЬНОЙ общеобразовательной школы. ния является органической частью профессиональной подготовки специалиста ФКиС;

2. Опыт использования физических упражнений как средства профилактики и лечения заболеваний уходит в глубокую древность. (Древний Египет, Древний Китай, Индия и д.р.).

3. Особое внимание в наши дни уделяется учащимся имеющим ограниченные возможности (глухим, слепым, умственно отсталым, с девиантным поведением, с нарушением осанки и т.д.). Для этой категории учащихся готовятся кадры специалистов способных вести профилактическую и лечебную работу средствами ФКиС. Открываются специальные классы и специализированные школы. Есть специальные учебные плааны и программы.

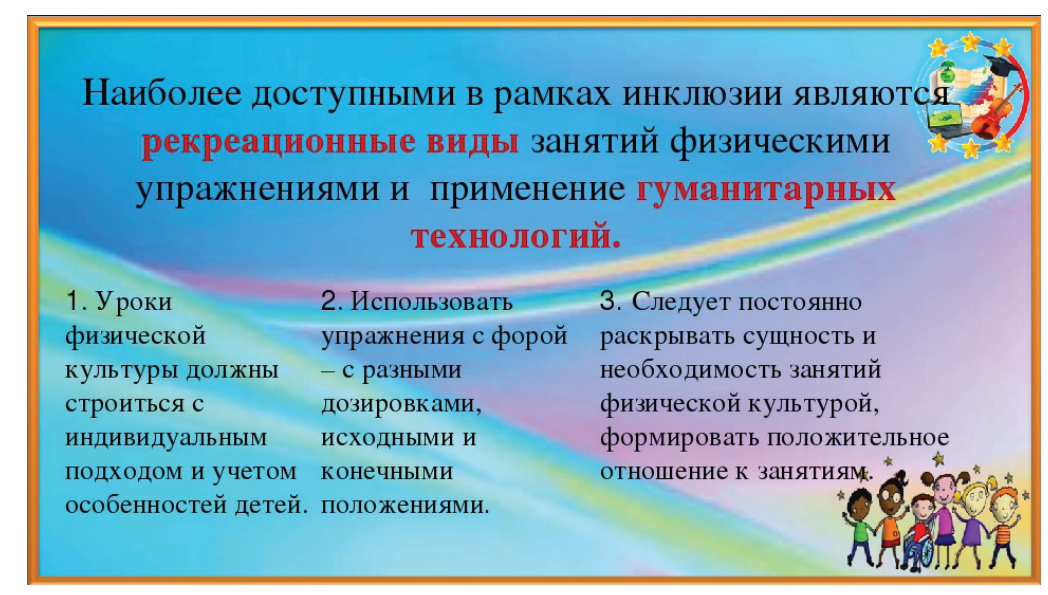

План:

1. Адаптивная физическая культура в системе физического воспитания современной специальной школы;

2. Понятийный аппарат изучаемой проблемы («адаптация», «адаптивная деятельность», «адаптивная физическая культура», «адаптивный спорт» и др.);

3. Необходимый уровень профессиональных знаний, умений и навыков по адаптационной физической культуре в деятельности современных учителей, спортивных тренеров, ученых;

4. Некоторые практические рекомендации по совершенствованию деятельности учителей школы, классных руководителей, тренеров по спорту.

\section{Лuтература:}

1. Адаптация. Энциклопедический словарь. т.1. М., ФиС, 1961, стр.23;

2. Адаптация. Краткий словарь иностранных слов. - М., Совет. Энциклопедия, 1968; 3. Адаптация социальная. Краткий политический словарь. Изд. 2-ое, дополненное. - М., Издат. полич. Литературы. 1980; 3. Жищенко А.Н. Корректирующие и развивающие упражнения для детей с нарушением интеллектуального развития. Методические рекомендации. - М., - Уральск, 2009; 4. Курамшин Ю.Ф. Координационные способности и методика развития. //Педагогика физической культуры. Под редакцией Б.А. Ашмарина, - СПб, 1990; 5. Развитие 
координационных способностей. В учебнике: «Теория и методика физической культуры. Курс лекций под редакц. Ю.Ф. Курамшина. - СПб, 1999, стр. 239 - 241; 6. Психологический словарь Под редакцией В.В. Давыдова. - М., Педагогика, 1983, стр.88.

Литературные данные дают основание утверждать, что за последние 5 лет число детей-инвалидов выросло более чем в 2 раза (Осадчих А.И., 2002). С 1996 по 2000 гг. увеличилось общее количество детей до 14 лет, страдающих болезнями: костно-мышечной системы - на 53,6\%; эндокринной системы - на 45,6\%; с врожденными аномалиями - на 41,8\% (Ильин Е.Т., 2002). Это обусловлено сложной социально - экономической, политической обстановкой в стране, увеличением производственного травматизма, бытовых, экологических катастроф, возникновением военных конфликтов, рождением детей с врожденными дефектами, а также частыми террористическими актами как в России, так и в государствах постсоветского пространства.

Сложившаяся в настоящее время кризисная ситуация в состоянии здоровья казахстанцев обусловлена, помимо прочего, недооценкой социальной роли физической культуры, в тоже время применение физкультурнооздоровительных средств и методов приобретает сегодня особое значение как для оздоровления, так и для приспособления инвалидов к жизни в обществе.

В последние годы в Казахстане активно развиваются теория и методика адаптивной физической культуры (Григоренко В.Г., Сермеев Б.В., 1991; Евсеев С.П., 1998), разрабатываются различные подходы к проведению занятий физическими упражнениями с людьми, имеющими различные травмы и отклонения в состоянии здоровья. Как правило, исследования носят комплексный характер. Выполнены исследования по физической культуре детей-инвалидов дошкольного, школьного возрастов и взрослых инвалидов по зрению (Никольская Т.Н., 1997; Ростомашвили Л.Н., 1999; Петрова Е.В., 2000; Макаренко О.И., 2000 и др.), детей со слуховой депривацией (Суханова Т.В., 1995; Смекалов Я.А., 2000; Крет Я.В., 2002 и др.), детей с задержкой психического развития и умственной отсталостью (Ильин В.А., 1992; Барабаш О.А., 1997; Литош Н.Л., 1998; Ванюшкин В.А, 1999; Веневцев С.И., 2000 и др.), лиц с нарушениями опорно-двигательного аппарата разной этиологии (Курдыбайло С.Ф., 1993; Ганзина Н.В., 1997; Черемных А.Д., 1998; Орешкина Ю.А., 2001; Жиленкова В.П., 2002 и др.), студентов-инвалидов (Хомутов Г.А., 1999; Шелкова Л.Н., 2000 и др.).

За последнее десятилетие в нашей стране накоплен обширный научный и методический материал по физической культуре инвалидов различных нозологических групп в виде учебных и методических пособий, монографий, авторских образовательных программ (Рубцова Н.О., 1995; Григоренко В.Г., Сермеев П.В., 1997; Мастюкова Е.М., 1998; Горская И.Ю., Синельникова Т.В., 1999 и др.). Вместе с тем, анализ специальной литературы показывает, что физкультурно-оздоровительная работа с инвалидами разных нозологических групп остается еще малоизученной.

На сегодняшний день адаптивная физическая культура предлагает достаточно много проверенных практикой, научно обоснованных оздоровительных методик. В то же время эти методики используются в основном с инвалидами, объединенными каким-то одним характер- 
ным заболеванием (например, нарушение слуха, задержка психомоторного развития, ДЦП, нарушение речи). При этом подобные группы формируются, главным образом, в специализированных лечебных профилактических учреждениях, где инвалиды объединены по конкретному заболеванию. Однако не все инвалиды имеют возможность заниматься физической культурой в составе своей нозологической группы по различным объективным причинам. Поэтому в последнее время стали культивироваться физкультурно-оздоровительные занятия с инвалидами, объединенными не каким-то конкретным заболеванием, а привязанностью к месту жительства, работы и прочими обстоятельствами. Вместе с тем, методика проведения физкультурно-оздоровительных занятий с инвалидами разных нозологических групп остается малообоснованной и недостаточно разработанной.

Проблема заключается в том, чтобы обосновать какие средства, методы и формы занятий физической культурой необходимо использовать в процессе занятий с инвалидами, относящимися к различным нозологическим группам, но занимающимися одновременно в одном и том же месте для улучшения их психического состояния, физической работоспособности и повышения приспособленности к жизнедеятельности.

Таким образом, в социальной действительности сложилось противоречие: с одной стороны, существует острая необходимость в использовании различных методик и средств физической культуры для оздоровления и адаптации инвалидов, имеющих различные отклонения в состоянии здоровья, но занимающихся совместно в физкультурно-оздоровительных группах, с другой - нет научно обоснованных методик для эффективного проведения физкультурно-оздоровительных занятий с подобным контингентом занимающихся. Указанные положения определяют актуальность настоящего исследования.

Для решения проблемы была выдвинута рабочая гипотеза, в основу которой было положено предположение о том, что каждое физкультурно-оздоровительное занятие с инвалидами, относящимися к различным нозологическим группам и объединенными в один коллектив, должно иметь две составляющие: базовую, учитывающую одинаковые возможности занимающихся, и вариативную, ориентированную на их индивидуальные возможности. Это позволит проводить занятия по месту жительства и эффективно решать задачи повышения общей физической работоспособности инвалидов, улучшения их самочувствия, активности и настроения, адаптации к современным условиям жизнедеятельности, внутри группового общения занимающихся.

Цель исследования - научно обосновать методику совместных физкультурно-оздоровительных занятий с инвалидами разных нозологических групп.

Достижение цели осуществлялось решением следующих задач:

1. Изучить состояние проблемы повышения двигательной активности инвалидов различных нозологических групп.

2. Теоретически обосновать методику совместных физкультурно-оздоровительных занятий с инвалидами различных нозологических групп.

3. Экспериментально проверить эффективность методики совместных физкультурно-оздоровительных занятий с инвалидами различных нозологических групп. 
Объект исследования: физкультурно-оздоровительные занятия с инвалидами 18-34 лет разных нозологических групп.

Предмет исследования: методика физкультурнооздоровительных занятий, направленных на повышение физической работоспособности и нормализацию психического состояния инвалидов 18-34 лет, имеющих различные дефекты в состоянии здоровья и относящихся к различным нозологическим группам.

Теоретико-методологической основой исследования являются: теория и методика физической культуры (Матвеев Л.П., Ашмарин Б.А., Выдрин В.М., Курамшин Ю.Ф.); теория и организация адаптивной физической культуры (Евсеев С.П., Шапкова Л.В., Курдыбайло С.Ф.); концепции частных методик адаптивной физической культуры (Евсеев С.П., Дмитриев А.А., Потапчук А.А., Ростомашвили Л.Н., Шапкова Л.В.); теория уровней построения двигательного действия (Н.А. Бернштейн); концепция коррекционно-развивающего педагогического воздействия (Л.С. Выготский).

Методы исследования: теоретический анализ и обобщение данных литературы, анкетирование, оценка функционального состояния, определение уровня физической подготовленности, различные виды опросов, педагогические наблюдения и т.п.

Практика работы с детьми и подростками имеющими ограниченные возможности показали, что в основе программы должны быть учтены:

- оздоровительные направленности тренировок и др. форм занятий;

- доступность, постепенность нагрузки и систематичность занятий;
- взаимосвязь средств тренировки и активного отдыxa;

- индивидуальность подбора физических упражнений и дозирования тренировки;

- систематичность контроля за результатами воздействия физически тренировки;

- учет возростных особенностей, состояния здоровья занимающихся;

- лечебный спорт должен стать органической частью всех мероприятий.

Следует иметь в виду, что одной и главных педа гогических задач является убеждение занимающихся в особой необходимх упражнений при условии систематического контроля.

Все сказанное позволяет заключить, что:

1. Дальнейшее развтие казахстанскго общества, суверенитет Республики, гуманизация процесса профессиональной подготовки специалистов по ФКиС обращает внимание на неоходимость более широкого использования краеведчских исследований в профессиональной подготовке специалистов. Особое внимание исследователи обращают на методику преподавания, воспитание и обученив. Это обстоятельство позволит не только еще более глубоко освоить методы нового типа научныого поиска, но и более широкого использоваия его результатов в образовательно-воспитательной работе, пропаганде спорта высоких достижений, формирования патриотизма средствами спорта высоких достижений, формирования стойких потребностей населения к ЗОЖ - здоровому, насыщенному интересными и полезными делами образу жизни;

2. Краеведческие исследования, знания научных 
основ физкультурно-спортивного краеведчесукого научного поиска обогатит специалистов новыми знаниями, , такназываемых, специальных школах для глухих, слепых, умственно отсталых и др. детей, подростков;

3. Думается, что уместно рекомендовать включение данного элективного курса: «Физическое воспитание специальных школ» на заключительном этапе профессиональной подготовки специалистов, в седьмом семестре, в конун заключительной педагогической практики студентов факультета.

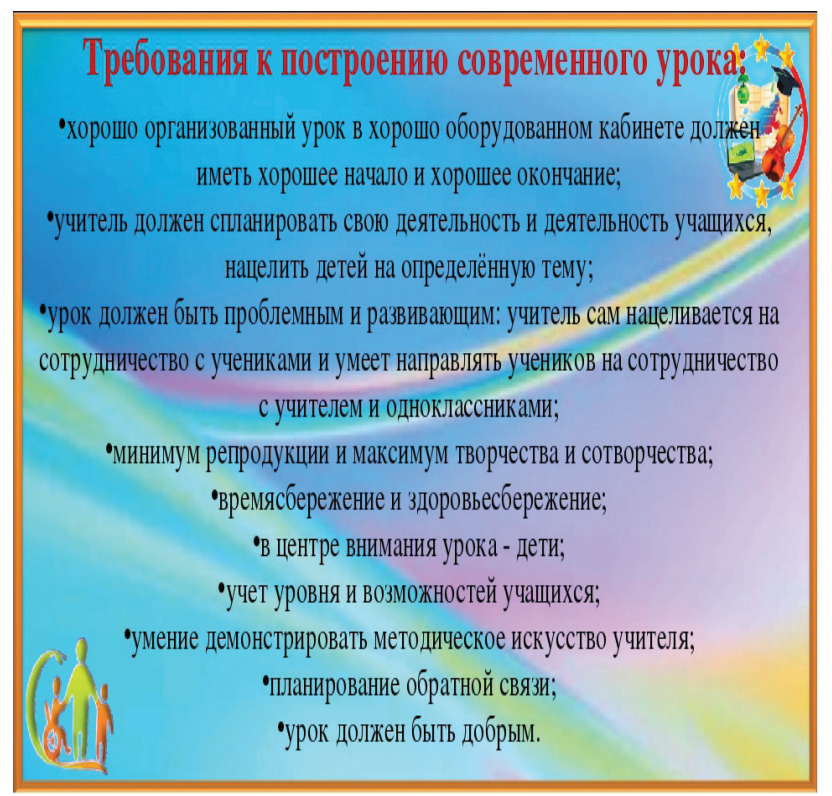

\section{Лекционное занятие 3-ье.}

\section{Tема: Методы научного исследования наиболее часто применяемые в специальных школах, физкультурно-спортивном, туристическом} краеведении.

План:

1. Методы исследования как инструмент для добывания и хранения научных краеведческих знаний;

2. Методы и приемы для осуществления краеведческого научности поиске;

3. Общенаучные методы исследовательского поиска и их использование в накоплении, обобщении краеведческих знаний, прежнего передового опыта;

4. Некоторые практические рекомендации по использованию методов научного исследования в современной педагогической практике воспитания и образования.

\section{Лuтература:}

Ашмарин Б.А. Теория и методика педагогических исследований в физическом воспитании. Пособие для студентов, аспитантов и др. - М., ФиС, 1978; Бережнова Е.В. и др. Основы учебно-исследовательской деятельности студентов. 3-е издание. - М., Академия, 2007, стр. 51; БубэКОМ Х. и др. Тесты в спортивной практике. Перевод с немецкого. - Берлин, Москва, 1968; Ганчев Д. Изучение и формирование общественного мнения. - М., Мысль, 1983; Ильина Т.А. Педагогика. Учебн. пособие для студентов. -М., Просвещение, 1984, стр.23; Краевский В.В. Методология педагогического исследования. Программа спецкурса и семинара. - М., Управление учебн. заведений Минпроса СССР, 1986; Методы педаго- 
гического исследования. Под редакцией В.И. Журавлева. - М., Просвещение, 1972; Методы исследования в теории и методике физической культуры. В кн: Ю. Курамшина и др. Теория и методика физической културы. Курс лекций. - С-Петербургская Гос. Академия физической культуры им. П.Ф. Лесгафта, 1999, стр.10; Формы и методы изучения «своей местности». В кн: Никоновой М.А. и др. Земледелие и краеведение. - М., Академия, 2000, стр. 222; Формирование научно-исследовательской культуры спортивного тренера. В кн: Пересветова Н.Н. и др. Педагогика физической културы и спорта. - Уральск, 2015, стр.73; Пересветов Н.Н. и др. Тесты в туристской практике. Методические рекомендации для учителей, ведущим исследования по комплексным темам. - Уральск, Дастан, 1996.

Творческий подход к вопросам обучения и воспитания учащихся средствами физической культуры, спорта и туризма предполагает и значительное возрастание требований к подготовке молодых специалистов по вопросам методов исследования. Способности молодых ученых широко использовать различные методы научного исследования и, в том числе, в краеведческой отрасли, в физкультурно-спортивном краеведении, Велика роль этих исследований и в исследовании особеннностей физического воспитания учащихся спецшкол.

В учебных и научно-исследовательских центрах постоянно ведутся поиски путей совершенствования учебного и учебно-тренировачных, воспитательных и др. процессов.А в целом - процессов профессиональной подготовки кадров специалистов способную работу не только грамотно вести воспитательно-образовательную работу, но и процесс, но и обеспечивать высокий уровень подготовки спортсменов, например, по Олимпийской программе, Паралимпийским видам состязания, Чемпионатам континентов (Европы, Азии и Мира). По другим видам спорта не входящим в Олимпийскую программу.

При этом следует помнить, что серьезные научные исследования сегодня проводятся не только в научных, научно-исследовательских и методических центрах. Они широко ведутся и в учебных заведениях всех типов (вузах, колледжах, ШОР и ДЮСШ), а также действующими спортсменами самостоятельно. Студентами, например, входящим в краеведческие научные объединения, типа: «Ни кто не забыт и ни что не забыто!» ведущих поиск в местах наиболее ожесточенных боев времен Великой Отечественной войны (1941 - 1945 гг.): Сталинград, Курск, Воронеж, Ленинград (Сакт-Питербург), Москва и др.

Практическая деятельность учителей физической культуры, спортивных тренеров, организаторов и пропагандистов, специалистов работающих в реабилитационных центрах (санаториях, профилакториях, домах отдыха и др.) Исследования предполагают уточнение отдельных понятий (терминов), как например, «Научная», «Научно-исследовательская», «Научно-методическая» и «Научно-практическая» другие виды деятельности.

В работах Б.У. Альмуханова, Б.А. Ашмарина, А.К. Кульназаров, Г.И. Кукушкина, В.М. Выдрина, Ф.И. Собянина и др. даются подробные разъяснения этим понятиям. Авторы, считают, что «Методическая» и «Научнометодическая» работы определяются, прежде всего, спецификой проводимых исследований, которые характеризуются направленностью поиска, например, на решениет задач совершенствования процессов обучения и воспитания. При этом научно-методическая работа, как правило, 
является частным случаем научно-исследовательской деятельности (Б.У. Альмуханов, Б.А. Ашмарин, Н.И. Понамарев и др.) тоже и в краеведческом научном поиске. Добыванием, сохранением краеведческих научных знаний и прежнего передового педагогического опыта.

Б.А. Ашмарин и его саратники разработали схему (Алгоритм) исследовательской деятельности, который мы предлагаем с некоторыми дополнениями и уточнениями:

1. Анализ литературы по изучаемой проблеме и существующего передового педагогического опыта;

2. Выбор и обоснование актуальности темы НИР;

3. Определение задач предполагаемого научного поиска (исследования);

4. Разработка научных гипотез (начальной и конечной, подтвержденной и отвергнутой);

5. Составление плана НИР;

6. Подбор испытуемых или контенгента исследуемых;

7. Выбор информативных методов научного исследования;

8. Подготовка помощников (соавторов) НИР;

9. Подготовка документов (протоколов и т.п.) для фиксации результатов поиска;

10. Сбор фактического материала и его обработка;

11. Оформление (обобработка существующующего опыта), осмысление собранных материалов;

12. Внедрение полученных результатов в существующую практику.

Продолжая мысль Б.А. Ашмарина (1978) и его саретников профессоров Б.У. Альмуханова Г.И. Кукушкин которые предлагают свои варианты последовательности работы над поисковой темой. Этот алгоритм включает следующие виды деятельности:
1. Ознакомление с литературными источниками по изучаемой научной проблеме;

2. Обобщение существующего практического опыта;

3. Уточнение задач и методов исследования. Формулирование и обоснование рабочей гипотезы;

4. Проведение опытной работы (собственных исследований);

5. Обработка материалов исследований и их анализ;

6. Подведение итогов, формулировка выводов и практических предложений;

7. Литературное оформление, подготовка иллюстраций, списка использованной литературы, приложений;

8. Выступление с докладом на конференции специалистов;

9. Внесение поправок;

10. Представление работы к печати.

Не пытаясь противопоставить мнения авторов, а лишь подчеркивая их взаимное дополнение, мы рекомендуем оба этих алгоритма для исследовательской деятельности, особенно, начинающих ученых.

К числу применяемых методов исследования относятся: Memodbl onpoca. Методы исследования этой группы сравнительно просты. Они широко применяются в социологии, политологии, декографии, а теперь и в краеведении. Существует три группы опросных методов: беседа, анкетирование и интервьюирование.

Беседа - это диалог исследователя и испытуемым по заранее разработанной программе. В процессе беседы могут допускаться вопросы «в лоб» и вопросы со скрытым смыслом. Например: - Как бы поступили Вы оказавшись на посту Государственного тренера по конкретному виду спорта? Ответ представлен по группам. 
Интервью. Этот метод, как показала практика, особенно эффективен в условиях неофициальных контактов. При использовании этого метода не следует допускать, чтобы опрос этим способом был похож на допрос.

Наряду с опросом устным и письменным сущесвует еще опрос с помощью анкет. Этот метод наиболее продуктивен особенно по части обработки полученных результатов. Иногда допускается анкетирование через прессу (газеты и журналы).

В практике часто используются анкеты трех видов: открытые, закрытые и смешанные. Открытые анкеты не содержат готовые ответы, а предполагают чтобы испытуемые написали собственное мнение на поставленный вопрос. Закрытые анкеты требуют выбрать ответ из трех-четырех возмодных ответов (Да. Нет, Затрудняюсь с ответом).

Вот, несколько примеров ответа на вопросы анкеты выявляющей склонность испытуемых к поведению в конфликтных ситуациях. Вот эти вопросы:

1. Можете ли Bbl удержаться от спора, когда большинство людей не согласны по принципиальным вопросам?

2. Конфликтуете ли Вы, когда охватывает ярость или проявляется не согласие большинства?

3. Прибегаете ли Вы к физической силе для зашить собственных Поступаете ли Вы наперекор людям, которые корчат из себя начальников?

4. Можете ли Вы стукнуть кулаком по столу для доказательств собственной правоть??
Методы научного исследования, применяемые в физкультурно-спортивном краеведении

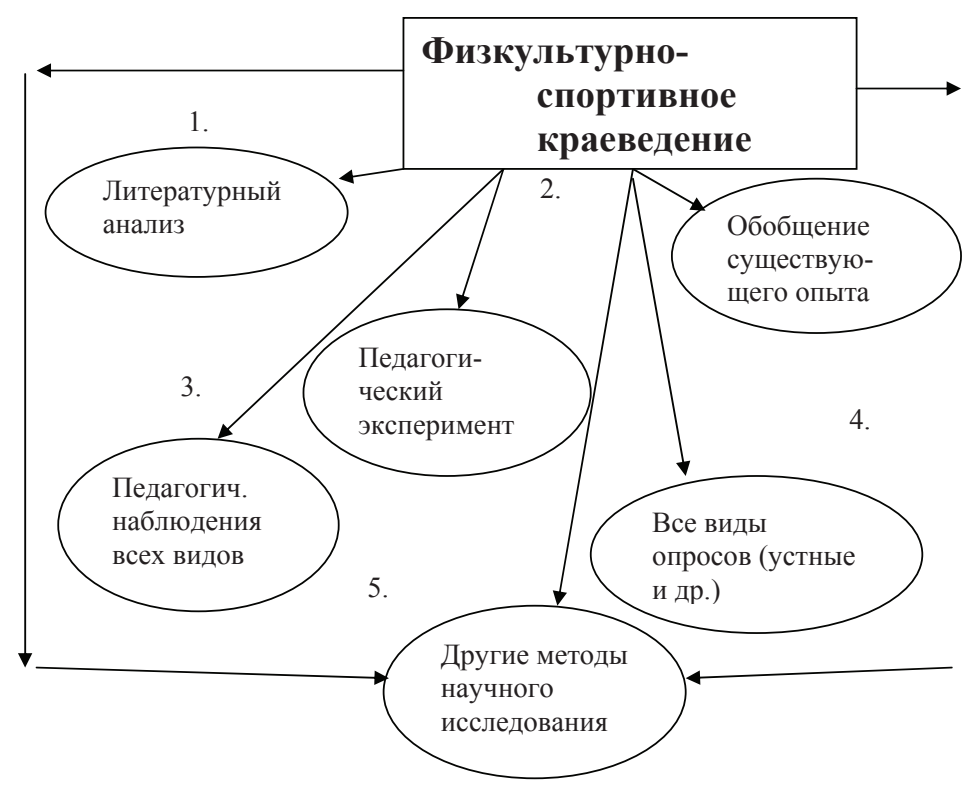

Результаты исследований

по выявлению склонности будущих специалистов ФКиС к конфликтным ситуациям.

$$
\text { ( в \%\%) }
$$


1. Может удержаться от спора, когда большинство людей не согласны по принципиальным вопросам:
а) Да, может - 40
б) Нет, не может - 20
в) Может, но только в зависимости
от конкретной ситуации - 30
г) Затруднился с ответом - 10

Графическое отображение результатов

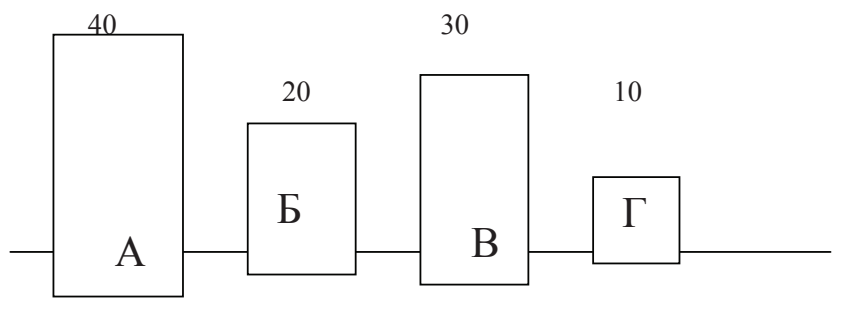

2. Конфликтует, когда охватывает ярость или проявляется не согласие большинства.
а) Да, конфликтует -30
б) Нет, не конфликтует - 40
в) Конфликтует в зависимости от ситуации $-20$
г) Затруднился с ответом - 10

Графическое отображение результатов

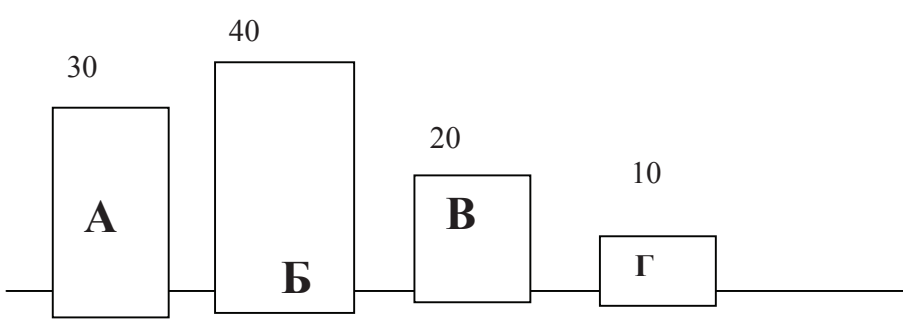

3.Поступает наперекор людям, которые воображают себя начальниками
a) Да, поступает $-10$
б) Нет, не поступает - 20

в) Поступает, но только в зависимости от $-50$ конкретной ситуации

г) Затруднились с ответом

Графическое отображение результатов

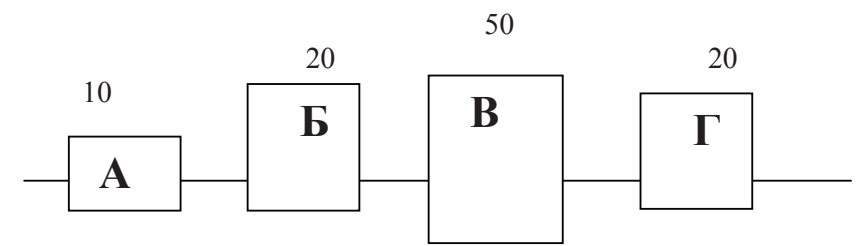

4. Прибегает к физической силе для защиты собственных интересов.
а) Да, прибегает $\quad-40$
б) Нет, не прибегает -20
в) Прибегает, но с учетом ситуации -30
г) Затруднились с ответом
$-10$

Графическое отображение результатов

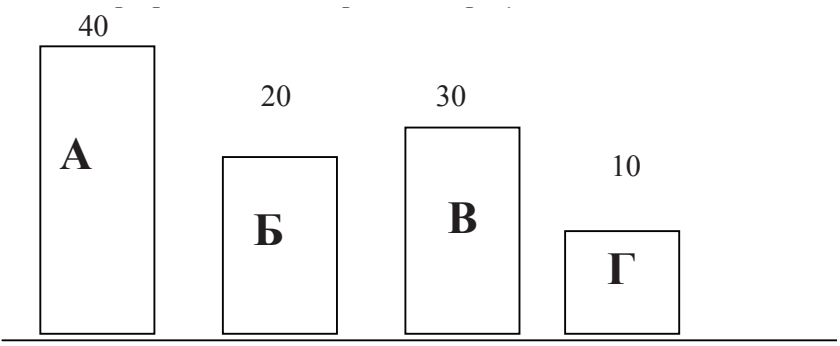


5. Может стукнуть кулаком по столу для доказательств собственной правоты
a) Да, могу стукнуть по столу кулаком - 40
б) Не могут $-10$
в) В зависимости от ситуации
г) Затруднились с ответом

Графическое отображение результатов

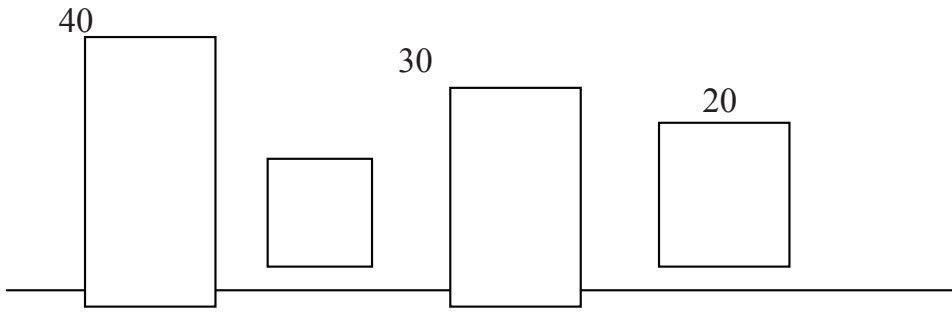

6. Говорит прямо в случае неодобрения действий своих знакомых.

а) Да, говорю прямо - 40

б) Нет, прямо не говорю -10

в) Говорю прямо в зависимости от ситуаций - 40

г) Затруднились с ответом

- 10

Графическое отображение результатов

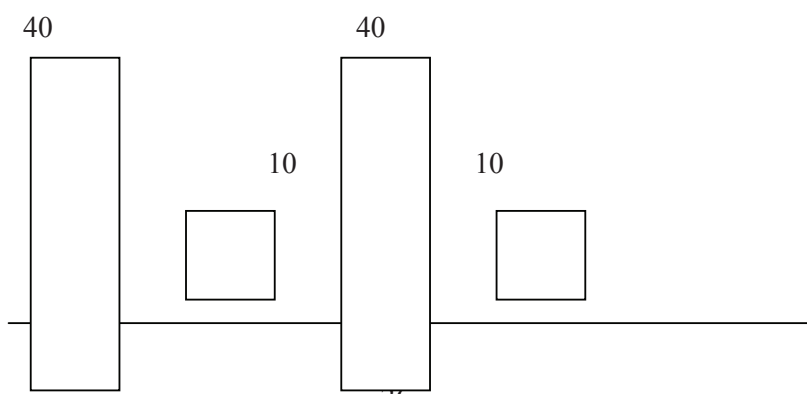

7. В сильном гневе употребляете ли Вы нецензурные (непечатные) выражения.

а) Да, употребляю непечатные выражения - 50

б) Нет, не употребляю

$-10$

в) Употребляю, но только

в зависимости от обстоятельств - 20

г) Затруднились с ответом или не ответили - 20

Графическое отображение результатов

50

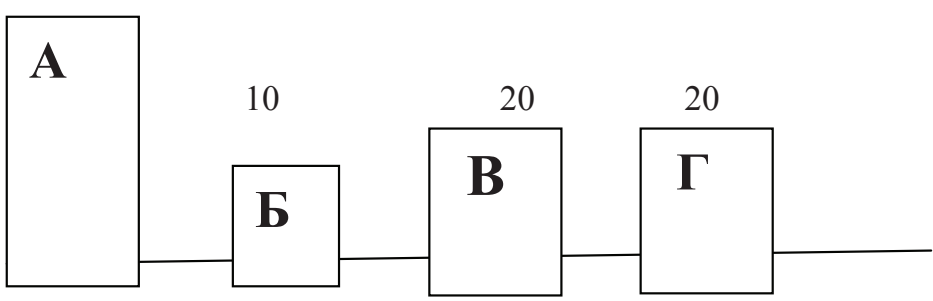

8.

- Если кто-либо на Вас поднимет руку, то постараетесь ударить его первым?

a) Да, постараюсь ударить первым -40

б) Нет, бить не буду $\quad$ - 20

в) Все зависит от

обстоятельств, ситуации - 30

г) Затрудняюсь с ответом - 10 
9. До занятий спортом у Вас часто «чесались кулаки» и Вы были намерены пустить в ход. - Сохранилось ли это желание теперь?

Да, сохранилось - 20

Нет, такое желание

отсутствует

$-40$

Все зависит от

обстоятельств - 30

Затрудняюсь с

ответом

$-10$

Графическое отображение результатов

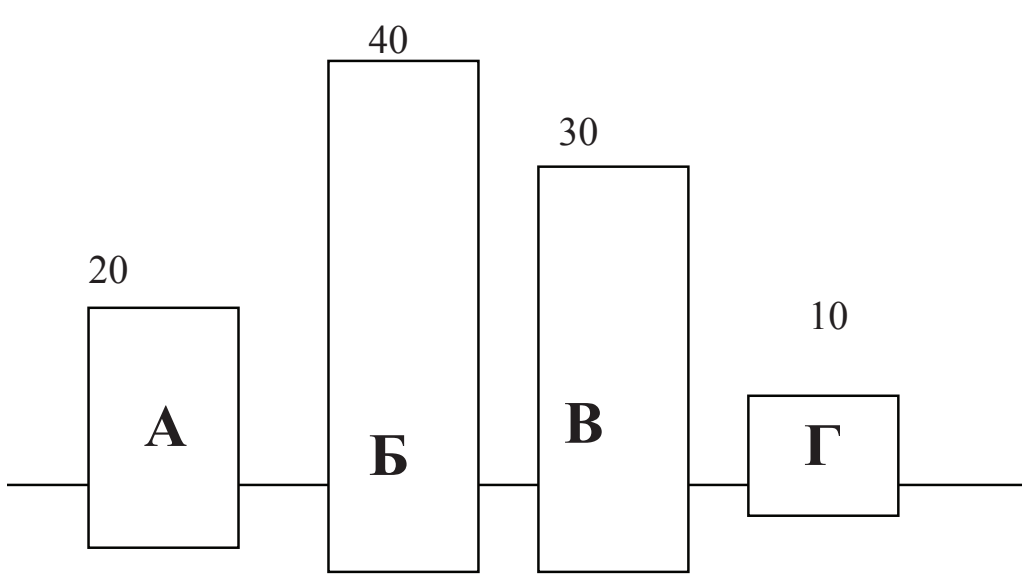

10. Возникла ссоры между Вашими товарищами по команде. - Как поступите Вы?
а) Предприму меры,
чтобы не вмешиваться - 30
б) Вмешаюсь и встану на
сторону потерпевшего - 20
в) Все зависит от
конкретных обстоятельств - 40
г) Затрудняюсь с ответом - 10

Графическое отображение результатов

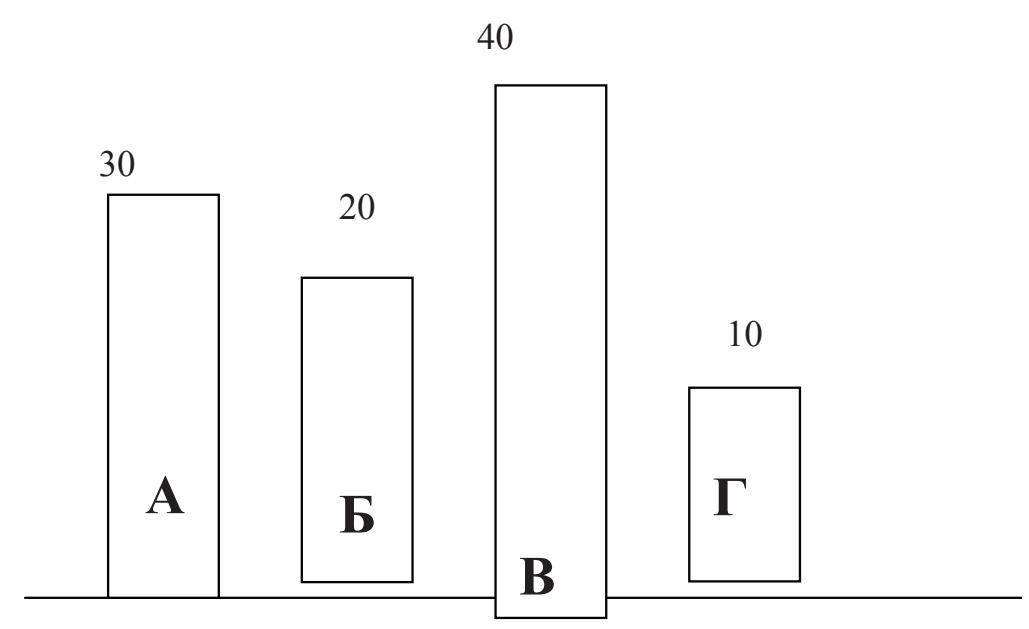


11. Если кто-то пытается вывести Вас из себя, можете ли Вы не обращать на это внимание?
a) Да, могу
$-40$
б) Нет, не могу
$-20$
в) Все зависит от обстоятельств
г) Затрудняюсь с ответом

Графическое отображение результатов

40
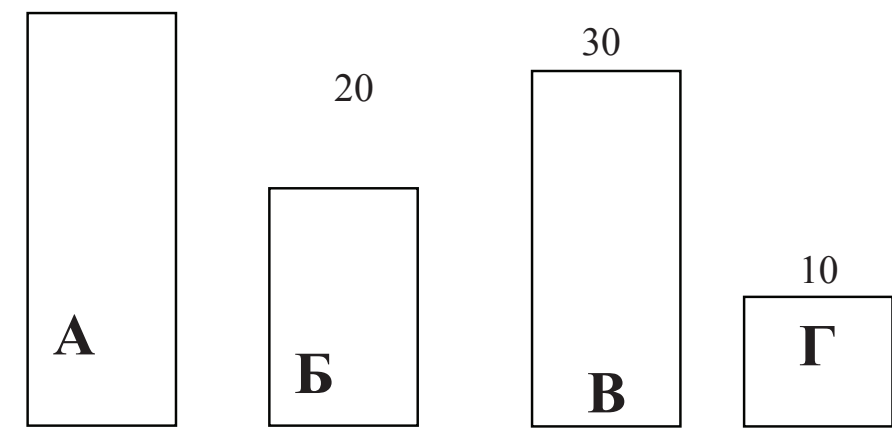

12. Как, по Вашему, можно ли средствами спорта регулировать степень конфликтности занимающихся.
а) Да, можно
$-40$
б) Нет, нельзя
$-20$

в) Можно, но только при наличие квалифицированных кадров педагогов $-40$

г) Затруднились с ответом

\section{Метод педагогического наблюдения}

Метод педагогического наблюдения является одним из наиболее распространенных из всех известных ранее методов педагогического исслдования. Практика физкультурно-спортивной, педагогической деятельности различает несколько видов наблюдения: открытое и склытое, непосредственное и обосредованное, сплошное и дискртное наблюдения (Б.А. Ашмарин, Е.В. Бережнова, В.В. Краевский и др.).

К разновидностям научных наблюдений в педагогике относятся открытые и скрытые виды наблюдений.

Открытое наблюдение означает, что испыуемым известно, что за ними ведется наблюдение и они сами могут наблюдать, как работает ученый, краеведисследователь.

Скрытое наблюдение предполагает, что наблдатель остается незамеченным, скрытым. Испытуемые не знают, что за ними ведется наблюдение. Наблюдение пожжет вестись с помощью технических средств:фотоаппаратов, кино-камер, звукозаписывающих приборов, специальной аппаратуры.

В арсенале методов исследования наблюдаются и еще два вида наблюдений: Лангитюдное ( продолжительнгое) и ретроспективное (Наблюдение обращенное в прошлое), Последнее больше всего приемлемо в краеведческих исследованиях. Материалы наблюдений фиксируются в специальных протоколах или дневниковых записях исследователей.

Творческий подход к вопросам обучения и воспитания средствами физической культуры, спорта и туризма предполагает и значительное возрастание требований к 
подготовке молодых специалистов. Способности молодых ученых широко использовать различные методы научного исследования и, в том числе, в краеведческой отрасли, в физкультурно-спортивном краеведении, в частности.

В учебных и научно-исследовательских центрах постоянно ведутся поиски путей совершенствования учебного и учебно-тренировачных, воспитательных и др. процессов профессиональной подготовки кадров специалистов способных не только грамотно вести воспитательно-образовательный процесс по физической культуре в учреждениях различного типа, но и обеспечивать высокий уровень подготовки спортсменов, например, по Олимпийской программе, Паралимпийским видам состязания, Чемпионатам континентов (Европы, Азии и Мира). По другим видам спорта не входящим в Олимпийскую программу.

При этом следует помнить, что серьезные научные исследования сегодня проводятся не только в научных, научно-исследовательских и методических центрах. Они широко ведутся и в учебных заведениях всех типов (вузах, колледжах, ШОР и ДЮСШ), а также действующими спортсменами самостоятельно. Студентами, например, входящим в краеведческие научные объединения, типа: «Ни кто не забыт и ни что не забыто» ведущих поиск в местах наиболее ожесточенных боев времен Великой Отечественной войны (1941-1945 гг.): Сталинград, Курск, Воронеж, Ленинград (Сакт-Питербург), Москва и др.

Практическая деятельность учителей физической культуры, спортивных тренеров, организаторов и пропагандистов, специалистов работающих в реабилитационных центрах (санаториях, профилакториях и др.) предполагает уточнение отдельных понятий (терминов), как например, «Научная», «Научно-исследовательская», «Научно-методическая» и «Научно-практическая» другие виды деятельности.

В работах Б.У. Альмуханова, Б.А. Ашмарина, А.К. Кульназаров, Г.И. Кукушкина, В.М. Выдрина, Ф.И. Собянина и др. даются подробные разъяснения этим понятиям. Авторы считают, что «Методическая» и «Научнометодическая» работы определяются, прежде всего, спецификой проводимых исследований, которые характеризуются направленностью поиска, например, на решениет задач совершенствования процессов обучения и воспитания. При этом научно-методическая работа, как правило, является частным случаем научноисследовательской деятельности (Б.У. Альмуханов, Б.А. Ашмарин и др.) тоже и в краеведческом научном поиске. Добыванием, сохранением краеведческих научных знаний и прежнего передового педагогического опыта.

Б.А. Ашмарин и его соратники разработали схему (Алгоритм) исследовательской деятельности, который мы предлагаем с некоторыми дополнениями и уточнениями:

1. Анализ литературы по изучаемой проблеме и существующего передового педагогического опыта;

2. Выбор и обоснование актуальности темы НИР;

3. Определение задач предполагаемого научного поиска (исследования);

4. Разработка научных гипотез (начальной и конечной, подтвержденной и отвергнутой);

5. Составление плана НИР;

6.Подбор испытуемых или контенгента исследуемых;

7. Выбор информативных методов научного исследо- 
вания;

8. Подготовка помощников (соавторов) НИР;

9. Подготовка документов (протоколов и т.п.) для фиксации результатов поиска;

10. Сбор фактического материала и его обработка;

11. Оформление (обобработка существующующего опыта), осмысление собранных материалов.

Все сказанное позволяет заключить:

1. В практике современных исследований по работе в специальных школах широко применяются общенаучные, педагогичекие исследования дающие возможность получения обобщенной информации;

2. Наиболее популярными методами являются метод педагогического наблюдения (открытое и скрытое), опроса и инте;

3. Особое место занимает метод эксперимента (формируюший, констатируюший и др.) проводимого, как правило, в естественных условиях

\section{Лекционное занятие 4-ое.}

Тема:Инновационная деятельность воспитателей, учителей физической культуры казахстанского Приуралья

План:

1. Учитель физической культуры в системе образования и воспитания учащихся школ всех типов;

2. Инновационная деятельность воспитателей детского сада, учителей общеобразовательных школы всех типов:

а) Деятельность педагогов-воспитателей дошкольных учреждений на примере детского ясли-сада №22 - «Колобок»;

б) Обеспечение межпредметных связей изучаемых общеобразовательных дисциплин и туризма на примере СОШ №20 - учитель Т.В. Харчева;

в) Инновационная деятельность учителей 5-9 кл. на примере СОШ №№ 7 и 17 - учителей В.В. Пашкина и Е.А. Кочетковой;

г) Инновационная деятельность учителей старших классов на примере СОШ №№ 1 и 23 - учителей В.В Новикова-Лаврова, Н.П. Панфилова и А.Г. Запрометова;

д) Активизация двигательной деятельности учащихся в режиме дня школы на примере школы-лицея № 35 - учителей В.В. Панкратовой и А. Келазева;

е) Другие краеведческие инновационные находки творчески работающих учителей-практиков, педагоговноваторов;

3. Критерии оценки деятельности учителей физической культуры работающих в общеобразовательных 
школах и внешкольных учреждений (ДЮСШ, ДЮСШОР, ШСМ, Центров туризма и др.;

4. Некоторые практические рекомендации по совершенствованию процесса профессиональной подготовки учителей на специальных факультетах .

\section{Лumepamypa:}

1.Громбах С.М. Школа и психическое развитие учащихся. М.:Медицина,1988. 2. Амосов Н.М. Раздумья о здоровье. 3-е изд. - М.: Физкультура и спорт, 1987; 3.Бальсевич В.К. Концепция альтернативных форм организации физического воспитания детей и молодежи. // Физическая культура: воспитание, образование, тренировка, 1996, № 1, стр. 23-25; 4. Пересветов Н.Н. К здоровью - через туризм. К здоровому образу жизни средствами туризма и краеведения. - Уральск, Полиграфсервис, 2000, стр.21 - 33; 5. Пересветов Н.Н. Повышение воспитательного потенциала урока физической культуры, как одной из ступеней реализации реформы школы. Методические рекомендации для учителей. - Уральск, ОблИУУ, 1995; 6.Пересветов Н.Н. Аспекты физкультурноспортивного краеведения. Учебно-методическое пособие. т. 2-й. - Уральск, Полиграфсервис, 2016, стр. 21 - 33 и 62 - 74; 7. Матвеев Л.П. Концепция образовательной программы «Физическая культура» для средней общеобразовательной школы. // Физическая культура: воспитание, образование, тренировка, 1996, № 1, стр. 19-22; 8 . Закон Республики Казахстан «Об образовании». №319111 ЗРК.

Говоря, о нетрадиционных подходах в воспитании, обучении и спортивной подготовке (тренировки) современных детей и подростков, занимающихся целенаправ- ленной двигательной деятельностью, физической культурой, спортом и туризмом. Деятельностью, которая часто используется педагогами, спортивными тренерами, пропагандистами, как средство образования и воспитания, следует воспользоваться, мнением писателя с мировым именем Анатоль Франса, который считал, что: «Искусство обучения есть искусство будить в юных душах любознательность, а затем удовлетворять ее».

Чаще всего эта деятельность реализуется педагогами, именно, нетрадиционными методами обучения и воспитания. И, более того, у каждого творчески мыслящего педагога, спортивного тренера, организатора физической культуры и других специалистов, имеются в запасе оригинальные приемы нетрадиционного решения основных задач урока физической культуры, спортивной подготовки. (А.П. Акушишников, В.В. Панкратова, Р.Б. Куватов, Е.В. Плотникова, А.Н. Новозенко, Т.В. Никишина, В.Л. Мельников и др.).

Из этого следует, что инновация в педагогике, методике физического воспитания, спортивной тренировке это глубокое взаимопроникновение, слияние, насколько это возможно, в одном материале обобщенных знаний, например, спортивной подготовки.

Впервые мы столкнулись с этой методикой, когда были приглашены в качестве руководителя педагогической практики студентов Пединститута в одну из общеобразовательных школ областного центра. (СОШ №32. Директор - В.В. Вовченко).

Было сообщено, что урок в предвыпускных - 10-х классах, будет проведен нетрадиционным (инновационным) методом. Тема урока: «Творчество, великого русского поэта А.С. Пушкина». 
Необычность проведения урока, на весьма, популярную, по тому времени, тему, которая состояла в том, что его (урок) были намерены вести сразу несколько учителей-предметников, представляющих различные учительские специальности: литературу, русский язык и историю, музыку, пение, рисование и черчение. Учителей других школьных предметов.

Учитель истории, например, была намерена сообщить учащимся о той социально-экономической и политической обстановке, в которой жил и творил замечательный русский поэт. Отношение к поэту царедворцев и самого царя, а также простого народа.

Учитель литературы планировала осветить биографию и творческий путь поэта. Личности писателей и поэтов, окружавших Александра Пушкина, творивших вместе с ним. Прочитать отрывки из его произведений. Например, «Письмо Татьяны к Онегину» или отрывков из повести «Капитанская дочка».

Учитель музыки и пения планировала сообщить (озвучить) музыкальные произведения, написанные на стихи А.С. Пушкина. Например, романсы на стихи поэта: «Я помню чудное мгновенье, передо мной явилась ты, как мимолетное видение, как гений чистой красоты...»

Учителя рисования и черчения планировали показать и дать комментарии к рисункам из произведений поэта. Таким, например, легендарным, как: «Сказка о Золотой рыбке», «... о спящей Царевне», «...о царе Солтане», «...о братьях разбойниках» и «33-х богатырях».

Один из учителей (учитель физической культуры), одев, черный плащ-мантию, такую какую носили во времена А.С. Пушкина и шляпу-цилиндр. Основательно загримировавшись, весьма успешно читал отрывки из произведений исторической прозы Александра Пушкина. О крестьянском восстании под руководством Емельяна Пугачева

Весь этот инновационный урок был рассчитан на четыре часа вместо 12 предусмотренных Министерской программой.

Эффект от урока был самым положительным и вполне, по нашему мнению, ожидаемый. Учащиеся, получили обобщенные (интегральные) представления и знанияо том историческом периоде, в котором жил и творил поэт. Том отношении, которое окружало Пушкина царский двор и лично Императора России. И, конечно, отношения к поэту простых людей.

Учащиеся познакомились с творчеством Пушкина и теми межпредметными связями, которые прослеживаются в преподавании дисциплин школьной программы (Литературы и Истории, Литературы и Живописи, Истории, Литературы и Вокального искусства).

Из этого следует, что описанный нами инновационный (нтегральный) урок, проведенный в СОШ №32, достиг ожидаемого положительного результата. Был высоко оценен присутствующими экспертами, педагогами других предметов, большинством учащихся.

Интеграционные или, как теперь говорят, инновационные методики проведения уроков применялись в наших школах, как выявилось, и в более ранние времена.

В годы Великой Отечественной войны (1941-1945 гг.) средние школы, как известно, были разделены на мужские и женские. В СОШ №6, ( г. Уральска), где учился автор данного методического пособия, уроки по литературе вел директор школы - Я.М. Родя. Он, например, один из уроков посвященный, творчеству В.В. Маяков- 
ского начинал «нетрадиционно».

Заходя в класс и чуточку громче, чем положено хлопнув дверью. Директор начинал, с порога, громко читать стихи Владимира Маяковского, например: «О Советском паспорте».

Я волком бы выгрыз бюрократизм,

К мандатам почтения, нету!

К любым чертям с матерями катись,

Любая бумажка, но эту...

Я достаю из широких штанин, Дубликатом бесценного груза.

Читайте, завидуйте.

Я гражданин Советского Союза!

И здесь, кто-то из присутствующих методистов ГорРайУНО попытается заметить: - А где же здесь традиционный алгоритм связанный с началом урока: проверка по журналу присутствующих, оглашение новой темы урока, проверка домашнего задания, изложение нового материала и т.п.

Сознаемся, что всего этого не было или мы просто не помним, но помнится, что был яркий монолог увлеченного педагога-новатора. Хорошо знающего и любящего творчество поэта. Или, как тогда говорили: «Агитатора, горлана, главаря».

Подводя итог сказанному, заметим, что нетрадиционные (инновационные) уроки, видимо, всегда присутствовали в школах. И всегда были в арсенале мастеров педагогического труда, творчески мыслящих и не стандартно действующих учителей. По предмету «Физиче- ская культура» - это были уроки с применением метода «Круговой тенировки», разработанного педагогом из Германии Манфредом Шоллихом.

И опять вопрос: - А может быть опыт СОШ №32 - это никакой не инновационный урок, а просто ... комбинированный урок, смонтированный усилиями нескольких учителей-предметников? Своего рода - урок-спектакль !? -Да, может быть и так. Но, согласимся, что именно такие уроки не обычены и интересены учащимся, а значит инновационны.

Обращаемся за помощью к словарям. Термин «Инновация» определяется (см. Краткий словарь Иностанных слов. - М, Советская энциклопедия, 1968.) как, что-то новое, необычное, какая-то новация (новшество), нетрадиционная находка, подход. Не избитое, или вновь найденное педагогическое действие.

Говоря о нововведениях, видимо, стоит иметь ввиду, что они могут быть не только положительными, но и отрицательными. Примером тому может быть откат качества образования СНГ, с четвертого места в мире (в бытность (ССР), на место в четвертом десятке государств мира.

Цель данного сообщения - высказать собственные суждения по оценке деятельности ряда учителей физической культуры работающих в различных учебновоспитательных учреждениях нашего региона, а на этой основе, обратить внимание общественности, молодых специалистов вступающих в жизнь, на содержание профессиональной деятельности, существующие противоречия, методические находки творчески работающих педагогов-новаторов. Учителей-воспитателей формирующих стойкую потребность учащихся к систематиче- 
ским занятиям двигательной деятельностью, особенно, средствами физической культуры, спорта и туризма.

Задачи сообщения:

1. Выявить группу творчески работающих учителей, воспитателей ведущих поиск путей совершенствования собственной профессиональной деятельности, преимущественно, средствами физической культуры и спорта. Вносящих, обоснованные предложения. Выступающие нововведения, на разного рода, методических совещаниях, конференциях или в специальной печати, по итогам «открытых» занятий;

2. Специалистов, стремящихся обоснованно совершенствовать учебно-воспитательный процесс за счет собственного опыта или опыта коллег почерпнутого из литературных и другого рода источников;

3. Учителей, вносящих предложения по совершенствованию педагогической деятельности в школах с учетом конкретных особенностей данного региона, области, республики. Предложения, подтвержденные собственными исследованиями с использованием оригинальны научных методик, обобщений, математической статистики и фактов.

Все это вместе взятое позволяет нам сформулировать гипотезу - научное предвидение ожидаемых результатов проводимой работы, которые сводились бы к следующему:

а) Совершенствование учебно-воспитательного процесса по физическому воспитанию, особенно, на этапе перестройки жизни современного общества, вызвано объективной необходимостью поиска оптимальных вариантов повышающих эффективность деятельности специалистов, всего учебно-воспитательного процесса школ региона, в целом;

б) Совершенствование учебно-воспитательного процесса, который подтверждался бы объективными изменениями в жизнедеятельности учащихся различных возрастов. Изменениями, связанными с нарастанием интеллектуальной нагрузки в учебном процессе, гиподинамией и стойкими нервными напряжениями, а также изменениями содержания культурных интересов в сторону далекую от жизненно-необходимой двигательной деятельности, научно-обоснованной физической культуры личности растущего организма.

в) Поиск оптимальных вариантов совершенствования учебно-воспитательного процесса в образовательновоспитательных учреждений должен, по нашему мнению, обязательно отмечаться администрацией, как морально-нравственно, так и материально.

Итак, предметом изучения является учебновоспитательный процесс по физической культуре и спорту конкретного воспитательно-образовательного учреждения, школы, детского сада, вне школьного учреждения спортивно-туристского профиля;

Гипотезы, как известно из литературы (Н.И. Понамарев, Г.И. Кукушкин, В.А. Ядов и др.) могут быть нескольких разновидностей: начальные и конечные, первичные, вторичные и т.д., подтвержденные и отвергнутые.

Нашей первичной научной гипотезой стало мнение, смысл которого сводится к тому, что использование опыта, ранее накопленного в регионе творчески работающими учителями, воспитателями, в повседневной педагогической практике станет побудительным механизмом для дальнейшего совершенствования целостного учебно-воспитательного процесса, отдельных его компо- 
нентов, например, приобщения учащихся к систематической двигательной деятельности, физической культуре, спорту и туризму. И всё это, в очередной раз, подтвердит значимость краеведческих исследований для современной педагогической практики.

Объект исследования - личность конкретного специалиста, (учителя, воспитателя) ведущего постоянный поиск путей совершенствования учебной или вне учебной деятельности конкретного воспитательнообразовательного учреждения (школы, детского садаяслей, ДЮСШ, турцента и т.п.), а на этой основе, именно этим успешно внедряющим стойкую потребность к ЗОЖ - здоровому образу жизни в быт учащейся молодежи.

В процессе деятельности нами широко использовались общенаучные и психолого-педагогические методы исследования: литературный обзор по изучаемой проблеме и обобщение существовавшего ранее передового педагогического опыта; различные виды опросов; педагогические наблюдения; формирующий и констатирующий педагогические эксперименты, проводимые, как правило, в естественных условиях; беседы и интервью, статистические методы обработки полученных результатов и научные обобщения. Другие методы.

Полученные результаты представлены в таблицах, графиках и рисунках.

Нами, например, обобщен и проанализирован опыт работы учителей, классных руководителей и воспитателей групп продленного дня, педагогов-воспитателей старших групп детских садов, школы-лицея, профтехшколы, общеобразовательных школ города и школ, расположенных в сельской местности.

Анализу была подвергнута деятельность учителей физической культуры, проявивших себя в нетрадиционных подходах при решении проблем физического совершенствования, воспитания и образования. Формирования личности занимающихся физической культурой, спортом и туризмом.

Обобщению опыта подлежала деятельность учителей: В.В. Новикова-Лаврова, СОШ №1; А.Г. Запрометова, СОШ №23; Т.В. Харчевой, СОШ №»20; В.В. Панкратовой и А. Келазква, школа-лицей №35; В.В. Пашкина, СОШ №7; Е.А. Кочетковой, СОШ№17; С.А. Щербань и А.Н. Козлова, сельской СОШ, Зеленовского района; С.А. Абуова, СОШ п. Новая Казанка, Жангалинского района, а также инновации в деятельности детского дошкольного учреждения - ясли-сада №22, со сказочным названием - «Колобок» (г. Уральск). Заведующая - О.Н. Конакова.

«Дошколята». Смысл инновационной деятельности воспитателей детского сада «Колобок» сводился, например, к тому, что один раз в неделю (по пятницам), в течение всего года, воспитуемые двух старших групп (44 чел.) отправлялись в «туристический поход» по заранее согласованным маршрутам. Всего маршрутов было три, протяженностью 1500-2500 метров. Конечным пунктом была избрана цементно-гибсовая скульптура «Трехголового змея Горыныча» расположенная в сосновой зоне Городского парка культуры и отдыха. Схемы маршрутов были заранее вывешены в игровых комнатах воспитанников старших групп. Разъяснительную работу с детьми, родителями воспитанников проводили педагогивоспитатели старших групп детского сада.

В этом случае еще раз, видимо, уместно обратиться к мнению Президента страны - Н.А. Назарбаева, который 
считает, что: «Как будут воспитывать нынешних учеников учителя, так они и будут трудиться и жить в будущем, таковым будет и уровень Казахстана». Эти слова актуальны, как никогда и в наши дни.

Подготовительной части инновационного мероприятия, особенно, в осенне-зимний период, отводилось особое место, которое реализовалась при обязательном участии родителей «Туристят». Главное внимание отводилось мотивации, одежде и экипировке участников походов, в которую входили обязательное наличие рюкзачка, соответствующего возрасту, капроновой фляжки или бутылочки $(0,25$ литра) с питьевой водой или чаем с лимоном и сахаром, альбомы для рисования, цветные карандаши или фломастеры, мячи и скакалки для подвижных игр на местности. Необходимая, для такого случая туристическая палатка, другие приспособления, например, для походного костра находились в рюкзаках двух педагогов-воспитателей, обязательно участвующих в данном мероприятии, сопровождающих группы.

При этом еще раз заметим, что вопросы одежды, особенно, в осенне-зимний период, специально оговаривались на совещаниях с родителями. В комплект входили: вязаная шапочка и шарфик, рукавички и шерстяные носки, удобная для похода обувь. В рюкзачках участников похода имелись специальные коврики («корпешки») для сидения на земле в момент отдыха (Размер коврика: 40 х 45 см.).

Вот как, например, организовывалось передвижение по маршруту №2, протяженностью около 2 тыс. метров. Поход проводился во второй половине октября. Погода устойчивая, сухая. При этом еще раз заметим, что на всем протяжении маршрута предусматривались три обязательные остановки, привалы, где, кроме отдыха, решались и воспитательно-образовательные задачи. Давались специальные знания: сообщались сведения о растениях встречающихся по пути следования, кустарниках и травах, полевых цветах и даже муравьях построивших свои домики вдоль дороги. Так, например, первый привал предусматривался уже через 300 - 350 метров начального пути. Этот привал (5-7 мин.) получил название «Подгоночный» ( см.рис.). За это время подтягивались отстающие. Восстанавливалась походная колонна. Воспитатели проверяли состояние одежды и обуви, самочувствие участников похода. Здесь же удовлетворялось желание «Туристят» сделать один-два глотка из фляжки (бутылочки) вкусного напитка, а также завязать шнурок, поправить шапочку и шарфик, одеть варежки, передохнуть.

Второй привал, всегда планировался через следующие 550 - 600 метров движения. На этом этапе турпохода подключался музыкальный руководитель с баяном. Звучала бодрая мелодия к знакомой детской песне:

«С нами весело шагать

По просторам, по просторам.

И конечно напевать

Лучше хором, лучше хором....»

Ребята приободрялись, оживлялись лица, появлялись улыбки. Это говорило о том, что остановка, рассчитанная на 8-10 мин, была особенно необходима. В этот отрезок времени «Туристята», как правило, повторяли хором речёвки, преимущественно, экологического содержания. Педагоги-воспитатели обращали внимание детей на деревья и кустарники, птиц и насекомых, траву и цветы, встречающиеся по пути следования. Сообщались также 
сведения о насекомых и их роли в жизни растений, необходимости оберегать все живое на Земле, «не обижать казявочек или мурашиков, не ловить бабочек». И вот привал подходит к концу. Опять звучит известная детям веселая мелодия. И походная колонна отправляется долее по маршруту.

Третьим привалом, в соответствие с ранее утвержденным планом похода, предусматривался через следующие 500-600 метров пути. Он получил название: «Привал Бабушки-Загадушки». На этом участке туристического похода детей встречают сказочные персонажи: «СтаричекЛесовичек», «Чебурашка, «Лисичка-сестричка», «Василиса Прекрасная», «Зайчик-побегайчик» и другие сказочные персонажи.

«Бабушка-Загадушка» принесла, как всегда, полную кошелку новых сказок, загадок, подвижных игр на местности и речёвок. А перед этим, готовясь к походы, дети уже научились перестраиваться из колонны по одному в колонну по два и наоборот. Овладели умениями передвигаться по лесу или среди кустарников, взявшись за руки, внимательно смотреть под ноги, не отставать и т.п. Уметь переходить встречную канавку по широкой доске, бревну или сваленному дереву. Прыгать с кочки на кочку, представляя, что они идут по вязкому болоту. Подлезать под обруч или встречающееся естественное препятствие, например, упавшее дерево. Придти на помощь тем, кто отстал, поскользнулся и упал. При этом еще раз заметим, что все эти препятствия были заранее предусмотрены планом работы, а их преодоление осуществлялось как средство комплексного педагогического воздействия. В походах формировались и успешно развивались необходимые для жизни двигательные качества: ловкость, бы- строта движений, выносливость и другие.

И вот походная колонна достигает конечной точки избранного маршрута. Это еловая роща - группа деревьев, произрастающих несколько обособленно от общей массы, а внутри нее находится сказочная фигура трехголового «Змея Горыныча».

Традиционно участники похода здороваются с лесом стихами:

«Здравствуй лес, чудесный лес,

Полон, сказок и чудес,

Кто в глуши твоей таится,

Что за зверь, какая птица?

Все открой, не утаи.

Ты же знаешь, мы... с в о и! (Громко, хором)»

По заданию педагогов - воспитателей, руководителей похода дети отгадывают загадки. Например: «Что за девииа, не швея, не мастерица. Ничего себе не шьет, а в иголках кругльй год?» (Елка). Или: «Ее узнаешь по простой примете - нет дерева белей на свете» (Береза).

Здесь же проводится подвижная игра-задание на знание листьев принадлежащих конкретному дереву: «Раз, два, три - за листочками клена, б е г и!». Педагогвоспитатель держит в высоко поднятой руке лист клена. Дети разбегаются и стараются подобрать из большой массы опавшей листвы нужной по конфигурации лист и назвать дерево, которому он принадлежит7

(Дуб. Клен, Береза).

Пребывание на природе, в лесу, городском парке, роще дети приучаются выполнять, привила поведения туристов: Не шуметь. Не сорить, Не ломать веток. Не обижать насекомых. 
Помогать соседу - участнику похода и т.п.

После активных двигательных действий - подвижной игры объявляется: «Минута отдыха, привал». Дети достают из рюкзачков альбомы и цветные карандаши (фломастеры) и тут же сидя на земле, рисуют в альбомах или обводят найденные ими листья деревьев. В это же время можно воспользоваться фляжкой с любимым напитком и сделать два-три глотка, утолить жажду.

Думается, что двигательные (физические) качества, формируемые в походах обязательно повлекут за собой и формирование личностных качеств «Туристят», например: готовности придти на помощь, упорству и настойчивости, доброты в общении и смелости, сопереживанию и моральной поддержки ближних, сильной воли.

Наши многолетние педагогические наблюдения, результаты педагогического эксперимента, убедительно доказали, что использование методики предложенной московским профессором, доктором педагогических наук А.А. Остапцом-Свешниковым способствуют приобретению детьми, новых знаний, умений и навыков. Знаний, необходимых для жизни, взаимоотношений человека с природой, развитию жизненно важных двигательных качеств и специальных умений, навыков.

Наши педагогические наблюдения были подтверждены мнениями родителей «Туристят». Они (родители) считают, что занятия такого рода - «Малым туризмом и краеведением», особенно интересны и полезны, носят познавательный характер, так как дети быстрее приобщаются к самостоятельной жизни, нарабатывают необходимые умения, многое узнают. Пытаются перенести полученные знания на взаимоотношения в семье, в играх со сверстниками, друзьями и подругами, братьями и сестрами. Дети привлекают к выполнению отдельных заданий даже, например, прохождению через канаву по доске или бревну, прыжков с кочки на кочку, других членов семьи: даже бабушек и дедушек. Но главное и это стоит особенно подчеркнуть, что дети осваивают девиз туристов всего мира: «Войди в природу другом!», «Не навреди!», «Сохрани все живое!», другие заповеди.

Наши медицинские обследования участников констатирующего педагогического эксперимента, проводимые совместно с медицинским персоналом детского сада показали, что занятия с использованием средств воздействия окружающей природы и свежего воздуха, целенаправленные двигательные действия, туризма и физической культуры, заметно сократили число и продолжительность простудных заболеваний, способствовали активному росту и развитию детей, хорошей посещаемости занятий.

Педагогический эксперимент (констатирующий) - 44 чел. проводился в естественных условиях воспитательнообразовательного процесса детского сада, с участием двух старших групп испытуемых (21 и 23 чел.). Возраст испытуемых - 5,4 года. Продолжительность эксперимента - один год. Принципиальных различий детей по полу, в эксперименте не учитывались. Полученные результаты (средние данные) представлены в таблице 1. 
Таблица 1.

Результаты педагогического эксперимента

по формированию двигательных качеств, специальных умений и навыков.

\begin{tabular}{|c|c|c|c|}
\hline Вид испытаний & $\begin{array}{l}\text { До начала } \\
\text { экспери- } \\
\text { мента. }\end{array}$ & $\begin{array}{l}\text { После } \\
\text { оконча } \\
\text { экспер }\end{array}$ & $\begin{aligned} & \text { Разница } \\
& \end{aligned}$ \\
\hline $\begin{array}{l}\text { Приседания на двух ногах } \\
\text { (колич. повтор.). }\end{array}$ & 5,40 & 8,20 & +2.80 \\
\hline $\begin{array}{l}\text { Наклоны туловища, руки на } \\
\text { поясе (колич. повтор.). }\end{array}$ & 7,20 & 15,20 & +8.00 \\
\hline $\begin{array}{l}\text { Метания в/б мяча из-за го- } \\
\text { ловы, на дальность (в см.) }\end{array}$ & 120 & 210 & $+90,0$ \\
\hline $\begin{array}{l}\text { Прыжки со скакалкой (кол. } \\
\text { подскоков). }\end{array}$ & 3,40 & 8,50 & $+5,10$ \\
\hline Равновесие на одной ноге & 4,0 & 10,40 & $+6,40$ \\
\hline -«Ласточка» ( в \%\%.). & 24,0 & 100,0 & $+76,0$ \\
\hline $\begin{array}{l}\text { Прохождение по узкой доске } \\
(\text { в \%\%). }\end{array}$ & 80,0 & 100,0 & $+20,0$ \\
\hline $\begin{array}{l}\text { Из виса лежа, подтягивания } \\
\text { на низкой перекладине (ко- } \\
\text { лич. повтор.). }\end{array}$ & 3,0 & 6,40 & $+3,40$ \\
\hline $\begin{array}{l}\text { Приседания на двух ногах } \\
\text { (колич. повтор.) }\end{array}$ & 5,60 & 12,20 & $+6,60$ \\
\hline
\end{tabular}

Анализ результатов представленных в таблице 1 . показали, что за время педагогического эксперимента произошли положительные сдвиги по всем показателям, определяющим динамику развития основных двигательных качеств испытуемых. Особых результатов дети достигли в метаниях волейбольного мяча на дальность (в сантиметрах) и прохождению через препятствие по горизонтально положенной доске (ширина 15 см.), что позволяет говорить и возрастании показателей их ве56 стибулярной устойчивости. В целом же, использование «Малого туризма» в воспитательно-образовательной работе детских дошкольных учреждений напоминает деловые игры, которые успешно зарекомендовали себя в учреждениях образования и воспитания. (см. подробно: Пересветов Н.Н. Деловые игры, как средство активного воспитательного воздействия - Уральск, УПИ им. А.С. Пушкина, 1989, стр. 79-82.).

Наши результаты подтвердила и заведующая детским садом «Колобок» - О.Н. Конакова, (Стаж работы более 20 лет). Другие педагоги-воспитатели.

Ольга Николаевна считает, что необходимость постоянного поиска нетрадиционных подходов к совершенствованию учебно-воспитательной деятельности педагогических коллективов дошкольных учреждений, несомненно, приводит к научно обоснованным положительным результатам. И, в частности, к формированию положительного отношения воспитанников к окружающей среде, флоре и фауне конкретного региона, а значит и общей экологической воспитанности «дошколят». Их уверенному вхождению в мир взрослых, подготовке к школе. Что же касается динамики развития жизненно необходимых физических качеств, то сам факт их активного развития не вызывает сомнений. Результаты звучат вполне убедительно и достоверно.

Подобные творческие находки говорят об актуальности подобного рода инновационных подходов к воспитанию и обучению, например, «дошколят» поможет формировать у воспитуемых устойчивое отношение к разного рода двигательной деятельности, а через деятельность и формированию необходимых для жизни двигательных качеств, умений и навыков, специальных 
знаний. Перенос же накопленного опыта д/с «Колобок», на деятельность других дошкольных учреждений вполне желателен. Это подтверждено педагогами детских садов «Жигер», «Яблонька» и др.

В наши дни только в областном центре успешно функционируют 50 государственных, 49 частных дошкольных организаций, 1 школа-сад, 29 мини-центров при общеобразовательных школах. По сравнению с прошлыми годами количество дошкольных организаций заметно возросло. Общий охват детей дошкольным образованием составил 15261 ребенок, из них в возрасте от 3 до 6 лет - 12977 (или 99,50 \%), а этот возраст вполне подходит, по мнению А.А. Остапца-Свешникова, к широкому использованию средств «Малого туризма», краеведения и экологического воспитания «дошколят».

Заключая информацию по использованию методики профессора А.А. Остапца-Свешникова и нашего скромного педагогического опыта по ее передачи, можно, видимо, с уверенностью утверждать эффективность формирования положительного отношения воспитанников детских садов к занятиям двигательной деятельностью средствами туризма. Проводить занятия в режиме учебной деятельности, которая подтверждается не только мнениями родителей и педагогического персонала детского дошкольного учреждения, но и объективными результатами динамики развития жизненно важных двигательных качеств, специальных умений, навыков и знаний.

Младшие школьники. Еще одним направлением проводимого нами краеведческого научного поиска было выявление эффективности инновационных действий учителей-воспитателей начальных классов. Обеспечения межпредметных связей между дисциплинами Учебного плана для младшего школьного возраста и требованиями к учащимся этой возрастной группы систематически занимающихся туризмом в группах Областного или Городского центров, где нам приходилось сотрудничать, работая по совместительству.

Для выявления эффективности были избраны учащиеся трех младших классов СОШ №20 (Директор - А.А. Тимофеева). Класс «А», руководимый учителем Т.В. Харчевой (27 чел.). Этот класс был объявлен экспериментальным. Класс работал по программе ОЦДЮТиК на протяжении всех четырех лет обучения. Два других класса («Б» и «В») выполняли контрольные функции. Всего под педагогическим наблюдением находились 120 учащихся: 68 мальчиков и 52 девочки, равных по возрасту и уровню физического развития, подготовленности.

Цель исследования - выявить положительную роль наличия межпредметных связей изучаемых учебных дисциплин младших школьников (1-4 классы). Знаниями и умениями получаемыми в процессе освоения туристической программы разработанной профессором А.А. Остапцом-Свешниковым.

Задачи исследовательского поиска:

1. Поиск оригинальных подходов по обеспечению межпредметных связей учебных дисциплин общеобразовательной школы для младших школьников и теми требованиями, которые предъявляются к этой возрастной группе при освоении программы Центров туризма и краеведения;

2. Экспериментально проверить эффективность программы для внешкольных учреждений подготовленной для младших школьников профессором А.А. Остапцом- 
Свешниковым;

3. Внести предложения по совершенствованию учебно- воспитательного процесса подготовки учителей начальной школы стремящихся обеспечить межпредметные связи учебных дисциплин общеобразовательных школ и внешкольных учреждений физкультурно-спортивной направленности - центров туризма и краеведения.

Гипотеза проводимого исследования включала следующие взаимоувязанные позиции:

а) Подтвержденная межпредметная связь изучаемых дисциплин должна обеспечить эффективность всего воспитательно-образовательного процесса младших школьников, что, видимо, будет просматриваться в уровне знания и умений, успеваемости и воспитанности учащихся;

б) Наличие межпредметных взаимосвязей изучаемых учебных дисциплин общеобразовательной школы и внешкольного учреждения - ОЦДЮТиК должно объективно проявиться не только в результатах субъективных оценок учителей и родителей учащихся (по пяти бальной системе), но и в конкретных умениях, навыках и знаниях, успеваемости учащихся;

в) Подтверждение же положительной роли межпредметных связей образовательных дисциплин с требованиями программы внешкольного учреждения - ОЦДЮТиК позволит и далее совершенствовать процесс разносторонней подготовки учащихся младших классов, а вместе с этим и профессиональной компетенции учителей.

В проводимом нами педагогическом исследовани широко применялись общенаучные методики позволяющие давать объективную оценку сдвигам, происходящим в личности учащихся систематически занимающимися двигательной деятельностью и, в частности, «Малым туризмом и краеведением». Программа воспитательного воздействия, по мнению А.А. Остапца-Свешникова, должна включать следующие взаимоувязанные позиции:

а) Польза приносимая учащимся младших классов человеку от занятий целенаправленной двигательной деятельностью, в частности «Малым туризмом»;

б) Деятельность, которая приводит к формированию у младших школьников положительного отношения к правилам, традициям и законам, формируемым в «Малом туризме»;

в) Прочное владение умениями и навыками формируемым в туризме (поставить палатку, разбить бивуак, развести костер и приготовить пищу, обеспечить экологическую культуру и пожарную безопасность места проживания, подготовиться к возможным изменениям погоды;

г) Самостоятельно подготовиться к следующему походу, взять все необходимое, правильно уложить вещи в рюкзак, не забыть документы и предметы личной гигиены, медицинскую аптечку;

д) Неукоснительно выполнять требования по гигиены питания и питьевому режиму, готовности оказать медицинскую помощь и самопомощь в походе или на привале;

е) Соблюдать требования туристов по бережному отношению к окружающей среде, природе родного края;

ж) Проявлять постоянное внимания участника похода друг к другу, особенно мальчиков к девочкам;

3) Другие требования. 
Учащиеся среднего школьного возраста

В современной педагогической практике все чаще и чаще звучат выражения: «Учитель - мастер», «Мастер педагогического труда», «Педагог - новатор», «Творчески мыслящий и действующий учитель», «Учитель от бога» и др.

Этими титулами, общественное мнение, коллеги и родители награждают, как правило, педагогов достигших вершин профессионального мастерства. Способных нестандартно вести уроки, добиваясь заметных успехов в образовании и воспитании учащихся. И такие учителя в нашем регионе имеются. Назовем только нескольких достигших заметных успехов в педагогической деятельности с учащимися старших классов. Это: Владислав Васильевич Новиков-Лавров, учитель СОШ №1 и Александр Георгиевич Запрометов, учитель СОШ №23, Вера Васильевна Панкратова, школа-лицей №35, Виталий Викторович Пашкин, СОШ №7 и Евгения Алексеевна Кочеткова, СОШ №17, Сатым Абуович Абуов, учитель СОШ п. Новая Казанка, Жангалинского района, учителя Алексей Николаевич Козловский и Сергей Александрович Щербань из СОШ, Зеленовского района ЗКО. Другие коллеги.

Согласовав свою деятельность с Управлениями образования города и области мы получили разрешение проанализировать деятельность учителя высшей категории СОШ № 23 А.Г. Запрометова.

По имеющимся данным, в деятельности этого педагога присутствует не только новаторский подход преподавания «Физической культуры», особенно, по разделу «Гимнастика» с применением разного рода отягощений и специальных тренажеров во второй учебной четверти, для учащихся старших (10-11) классов. Но и некоторые методические находки в организации пришкольного городского оздоровительно-спортивного лагеря для педагогически запущенных, «трудных» детей и подростков. Такой лагерь традиционно действует при школе в период летних и зимних каникул. Ряд других интересных воспитательно-образовательных действий учителя и всего педагогического коллектива школы (Директор Т.Н. Веденко).

Целью нашего краеведческого поиска было - выявить механизмы, формирующие эти возвышенные педагогические звания: «Педагог-новатор», «Мастер педагогического труда» и тот стиль работы, который присущ педагогам, мастерски проводящим занятия, организующих внеклассную и внешкольную работу по физическому совершенствованию учащихся, активно пропагандирующим здоровый образ жизни и физическую культуру.

Задачи краеведческого поиска:

1. Выявить и обобщить опыт учителей обладающих творчески направленной личностью, особенно компетентных в избранной педагогической профессии, избранной учительской специальности;

2. Сопоставить достигнутые результаты с общепринятыми требованиями к специалистам этого профиля;

3. Внести обоснованные предложения по дальнейшему совершенствованию профессиональной подготовки специалистов - бакалавров, а потом и магистров физической культуры и спорта. 


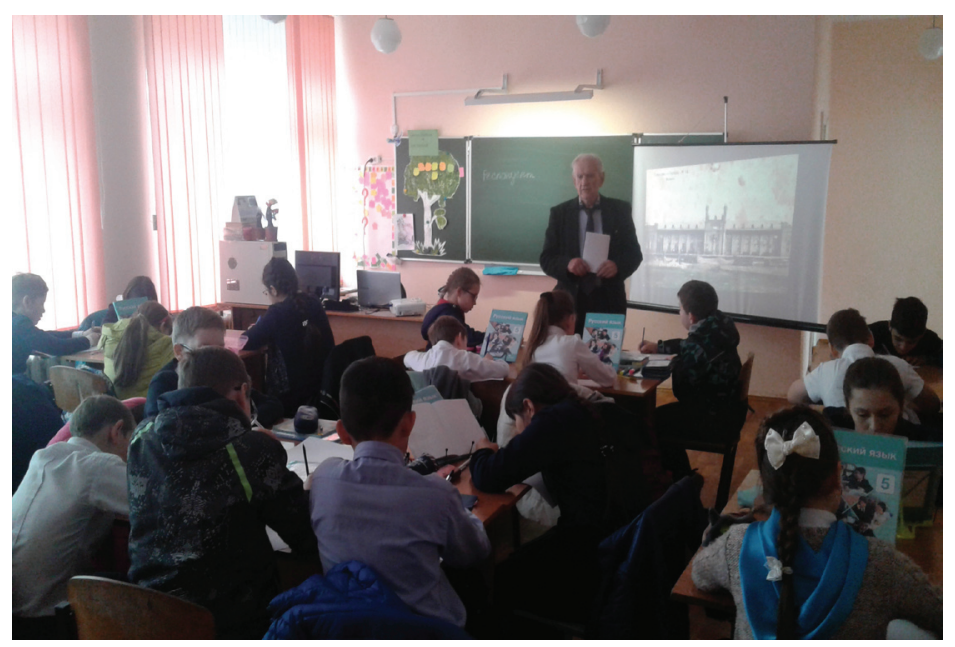

Рис 1. Урок ЗОЖ в КГУ « СОШ № 3 «г.Уральска. Классный руководитель Кузнецова А.Н.

Ожидаемый результат (гипотеза) - встретить хорошо организованный воспитательно-образовательный процесс преподаваемого предмета с наличием необходимой материально-спортивной базы, действенными средствами агитации и пропаганды, хорошо поставленной внеклассной работой кружков и спортивных секций, а главное, и мы это особенно подчеркиваем, с наличием у большинства учащихся, положительного отношения к предмету «Физическая культура». Отношения, с явно выраженным стремлением к физическому самосовершенствованию, через посещение вне учебных занятий, как в стенах школы, так и за ее пределами (ДЮСШ, Тур. Центры, ШСМ). В других внешкольных учреждениях физкультурно-спортивной направленности.

По совету работников городского управления образования мы посетили СОШ №23 (Директор- Т.Н. Веден- ко). Нас встретил слегка седеющий педагог, который по своему внешнему виду и выправке больше напоминал отставного кадрового военного. Знакомство, естественно, началось с осмотра материально-спортивной базы. Первое впечатление нас вполне устроило, но теперь несколько слов о самом «Новаторе». По мнению Александра Георгиевича, люди после пятидесяти лет начинают активно стремиться к пенсии, но насколько мы могли судить, А.Г. Запрометов об этом даже не помышляет: в свои 60 он продолжает успешно упражняться с гирями и бегать кроссы, увлекая этими занятиями большинство учащихся. Особенно старшеклассников. По мнению учителя, в этом возрасте только и начинается полноценная жизнь, когда физическую культуру можно не только преподавать, но и, через предмет, преподать ученикам определенную житейскую мудрость, сформировать личностные качества, например, возможность самосовершенствования как физического, так и моральнонравственного.

Касаясь биографических данных учителя А.Г. Запрометова, заметим, что он женат, имеет двоих детей - сына и дочь. Награжден нагрудным знаком «Отличник образования Республик», победитель конкурса «Учитель года-2002», участник Республиканского съезда учителейноваторов в г. Кустанае. Обладатель Благодарственного письма Президента Казахстана, за активную педагогическую деятельность и достигнутые результаты. В письме, в частности, говорится: «История выбрала наше поколение, на крутом переломе вверив нам судьбы страны. Мы верили в себя, мы не жалели своих сил и труда для того, чтобы возвести прочный фундамент современного государства и процветающего демократического общества. 
Вы - один из тех, чей беззаветный труд стал частью этого фундамента. Я горд тем, что на этом нелегком пути меня окружили такие современники». - Нурсултан Назарбаев.

В личном архиве учителя А.Г. Запрометова имеется и персональный приз - «Хрустальная севрюга», врученный за успехи туристов-краеведов школы в Республиканских соревнованиях.

Запрометов А.Г. - почетный профессор Московской академии детско-юношеского туризма и краеведения. Бессменный, более 30 лет, главный судья городских туристических соревнований школьников и учителей. Всю сознательную жизнь без перерыва работающий в СОШ №23. Итак, перед нами скромный, но, несомненно, талантливый, увлеченный, творчески мыслящий педагог, чей труд неоднократно отмечался на самом высоком уровне.

На наш вопрос: - А были ли в жизни случаи, когда Вас, уважаемый Александр Георгиевич, незаслуженно обижали, обходили вниманием? - Да, были, и я это буду помнить, наверное, долго, - отвечает Запрометов А.Г. А было это в самом начале моей педагогической карьеры. Команда учащихся школы в очередной раз заняла первое место в соревнованиях по спортивному туризму. Ребят наградили тогда путевками в известный всему миру лагерь «Артек». Радости у победителей было, как говорят в народе, «выше крыши». Но тогдашняя заведующая городским управлением образования решила по-своему: она отдала путевки отличникам городских школ с объяснением: «Они, кроме книг ничего весь год не видят, пусть поедут и отдохнут...».

- Конечно, такое решение было для нас очень обидным,
- вспоминает А.Г. Запрометов. Учитывая, что в «Артек» съехались самые сильные спортивные команды страны по спортивному туризму, наши «отличнички», по всем видам программы, с треском провалились, «но зато отдохнули на море». - Обидно, согласитесь, и очень.

Анализ учебных занятий по физической культуре в СОШ №23 показали, что учитель А.Г. Запрометов органично включает в учебный процесс элементы спортивного туризма и атлетизма - занятий с гирями различных весов, которые с интересом воспринимают как юноши, так и девушки. Одним из показателей было 100процентное посещение занятий, успешное выполнение нормативов Президентских тестов. На наш вопрос учащимся: - Как они оцениваю занятия по физической культуре, отвечают: - Какой смысл «сваливать» с занятий, если мы с пацанами, тем же самым пытаемся заниматься самостоятельно, объяснил один респондентов. Занятия интересны даже потому, что сила мышц прирастает весьма заметно.

Первую гирю, как сообщил нам учитель, он привез из г. Караганды и только потом в Уральске отлил, через знакомых, еще десяток новых. Теперь в школе атлетизм в особом почете. Им увлечены как юноши, так и девушки. Девушки-сташеклассницы считают, что «хорошая, в меру развитая мускулатура еще никому не была помехой». И с этим мы тоже полностью согласны. В школе имеется полный набор приспособлений для атлетизма: гире, гантели и специальные устройства.

- Дети, они ведь такие загадочные существа, - говорит Запрометов, - им, если не интересно, то никакое занятие впрок не пойдет. А я могу и за ухо оттаскать, если необходимость возникнет. Но и тренировки стараюсь так 
строить, чтобы даже мысли не возникало: «а на фиг мне эта физра сдалась!?».

- Что же касается туризма, то это «любовь» на всю жизнь. Его мы проводим преимущественно во время работы трудового, оздоровительно-спортивного лагеря. Я же лично раз в году, весной отправляюсь на сплав по большой воде в Урале. А по окончанию сплава, провожу традиционный учительский слет педагогов школ города, в качестве главного судьи соревнований. И этим занимаюсь уже более 30 лет.

- В приобщении же педагогов различных предметов школ города к туристическо-краеведческой, экологической деятельности вижу действенное средство привлечения учащихся к здоровому, насыщенному интересными и полезными делами образу жизни, который немыслим без целенаправленной двигательной, познавательносозидательной деятельности. Этим, на наш взгляд и осуществляется, так называемая обратная связь педагогического труда учителя физической культуры со своими учащимися.

Касаясь деятельного школьного трудового, оздоровительно-спортивного лагеря, заметим, что он существует уже более десяти лет (с 1997 года) и, наряду с оздоровительными задачами ставит и приобщение педагогически запущенны, «трудных» учащихся к общественно-полезному труду. Ребята собирают лекарственные травы, сушат и снабжают ими свой медпункт, заготавливают для школы веники, метлы. По договоренности с местным лесничим прореживают и расчищают лес, делают черенки для лопат и грабель. Все это ощутимое подспорье для родной школы.

К сказанному заметим, что желающих попасть в ла- герь всегда больше, а поэтому приходится проводить конкурсный отбор. В первую очередь берем детей из малообеспеченных семей, так называемых, «трудных» ребят, которых хоть на небольшой срок лагерь отбивает от улицы. Надо сказать, замечает директор школы Татьяна Николаевна Веденко, ни один из наших воспитанников не попал на учет в детскую комнату милиции. Это наша, несомненна, педагогическая победа.

И еще один ответ мы просим дать на несколько «неудобно» поставленный вопрос: - А есть ли у Вас предложения по оценке эффективности деятельности школьных учителей физической культуры? - Да, такие предложения есть, - заключает А.Г. Запрометов.

- На наш взгляд, многие недостатки школьного обучения и воспитания проистекают из-за отсутствия научнообоснованных критериев оценки деятельности учителя, воспитателя в соответствие с которыми определяется уровень их компетентности, эффективности затраченного труда, стремления к самосовершенствованию и, в конце концов, уровня материальной обеспеченности.

Захватившие нашу страну рыночные отношения еще более обострили эту проблему. В настоящее время работу учителя физического воспитания школы, педагогов дошкольных воспитательно-образовательных учреждений, оценивают весьма поверхностно. Главным образом на основе количественных показателей (число учащихся, выполнивших тот или иной норматив программы, получивших спортивный разряд, победивших в соревнованиях и т.п). Такой подход, по нашему мнению, нередко, приводит к пресловутой процентомании, к серьезным нравственным и профессиональным издержкам. И, как следствие, к соответствующему поведению самого учи- 
теля, воспитателя. Думаю, что с этим далее соглашаться нельзя.

Наносит такой подход, естественно, и существенный вред качеству педагогической деятельности, поскольку учитель отчетливо понимает, что дирекцию школы, Районные, Городские отделы образования, спорткомитеты, военкоматы интересуют, в подавляющем большинстве случаев, лишь усредненные количественные результаты. Да и зарплата учителя зависит не столько от качества и эффективности его педагогической деятельности, сколько от количества (объема) учебной нагрузки. Количества проведенных им уроков, стажа работы и соответствующего образования.

Видя порочность такого подхода, ряд специалистов предлагают несколько по-новому оценивать эффективность деятельности учителя физической культуры. В основу предлагается положить два основных слагаемых: показатель состояния здоровья учащихся и уровнь их физической подготовленности. Эти критерии нам кажутся главными.

Учеными установлено, что состояние здоровья человека примерно на 50\% определяется его образом жизни, где на долю здравоохранения приходится всего лишь $10 \%$ используемого времени, а вот роли остальных компонентов (экологической обстановки в регионе проживания, рациональному питанию, режиму работы и отдыха, соблюдению гигиенических процедур и т.п.) отводится значительно большее внимание. Существенным фактором влияния на здоровье человека считается и наследственность (20\%). Поэтому, если за один из основных критериев эффективности деятельности учителя взять состояние здоровья детей, то уже на исходных позициях педагоги будут поставлены в совершенно неравные условия. Проживающие, например, в зоне чернобыльской аварии, даже при отличной работе учителя, будут иметь худшие показатели, чем те, кто живут в регионах с более благоприятными экологическими условиями.

Если же в качестве, основного показателя взять только количество посещенных занятий, то опять могут возникнуть противоречия, относительно качества физической подготовленности. Наличия у учащихся специальных знаний, умений и навыков. 


\section{Лекционное занятие 5-ое.}

\section{Тема: Образовательно-воспитательная работа}

с детьми и подростками, имеющими отклонения

в интеллектуальном развитии.

План:

1. Интеллектуальное развитие как предмет изученияи.

2. Слабослышащие и глухие учащиеся: особенности физического воспитания и физического образования;

3. Возрастные и личностные особенности детей с различными формами отклонений и использование физических упражнений;

4. Учебная и внеклассная работа с детьми имеющими отклонения в органах слуха;

5. Рекомендации по совершенствованию профессиональной подготовке специалистов ФКиС.

Лumepamypa:

1. Власова Т.А. и др. О детях с отклонениями в развитии. 2-е издание исправл. и дополнен. - М., Просвещение, 1973;

2. Никуленко Т.Г. и др. Коррекционная педагогика. 2-ое издание. -Ростов н/д, Феникс, 2009;

3. Теория и практика физической культуры. Лекции, - СПб, 1999; 3. Жищенко А.Н. Коррекционные и развивающие уражнения для детей с нарушением интеллектуального развития. Метдические рекомендации. - Уральск, 2009, стр. 68;

4. Дубровский В. И. Лечебная физическая культура Учебник, 1999,
Болееглубокое изучение особенностей воспитательнообразовательной работы с детьми и подростками имеющими откл.онения в физическом и психическом уровнях развития требует обстоятельного раскрытия ведущих впонятий темы: «Интеллект», «интеллектуальное развитие», «интеллектуальность». Авторы БСС, т.10, стр. 311, считают что эти понятия трактуются как познание, понимание, рассудок. В современной психологии термин «интеллект» употребляется в теории индивидуальногот развития. В более широком смысле - «Интеллект» выступает как синоним умственного развития.

Замечено, что дети приходят в школы с различным уровнем двигательного опыта, а количество часов выделяемых на физическое воспитание крайне недостаточен для компенсации диспропорции между потребным количеством и возможным, нобходимым. Обращает внимание испытуемых и внешний вид испытуемых, который отличается тем, что голова школьников несколько опущена, наблюдается шаркающая помходка и стопы повернуты несколько внутрь. У некоторых детей отмечаются некоторые раскачивания туловища из стороны в сторону. (А.Н. Жищенко и др.).

При выполнении, например, бега наблюдается некоторая напряженность или отклонения вперед (назад), раскачивания в стороны. Все эти рекомендации только частично способны решать проблемы правильного бега, прыжков,лазания (перелезания). Большего результата испытуемые добиваются при участии в разного рода подвижных играх, где дети более полнее реализуют свои потребности в движениях («Вороны и впробьи», «Охотники и утки», «Акрабатические эстафеты» и др.). 


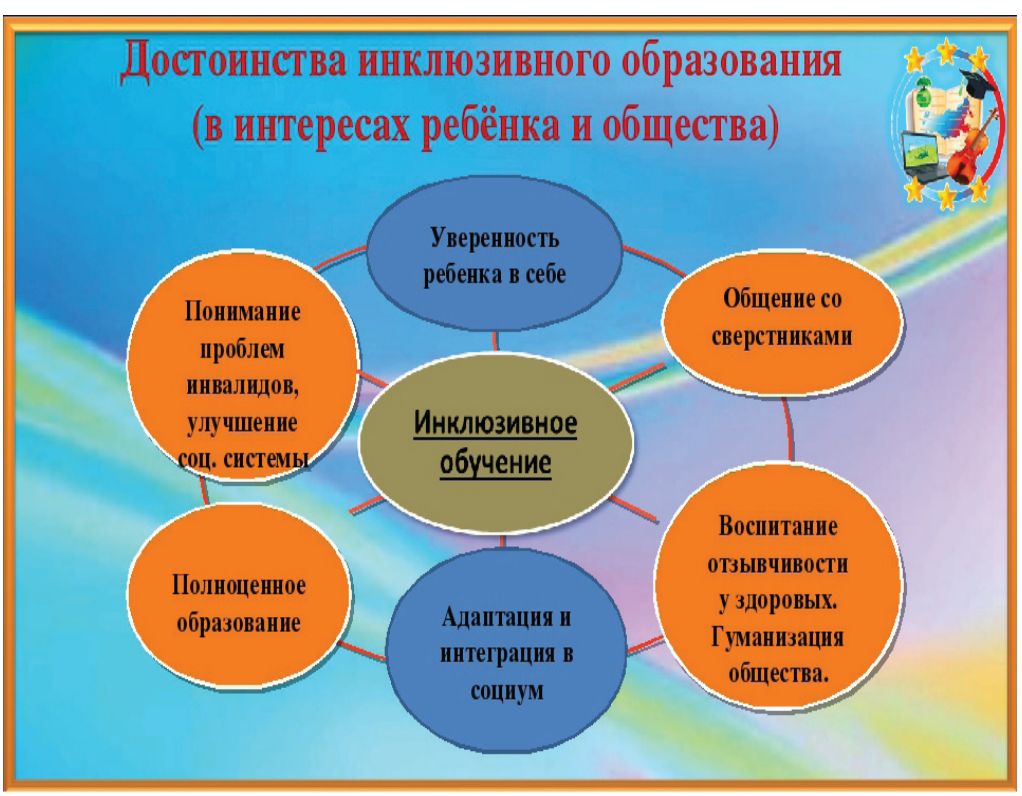

Заключение:

1. В числе принципиальных понятий изучаемых в данной проблеме есть понятия «Интеллектуальныц ировель развития личности школьников», «Уровень Интеллекта», «Интеллект и т.п. Эти понятия нуждаются 6 детальной расшифроке, понимании, что, несомненно, окажет позитивное воздействие на уровель общего интеллекта, грамотности уровень образованнолсти учащихся в целом.

2. На уровень интеллекта, оказывают положительнюе воздействие различные подвижные игры, состязания и соперничество, в виде тематических эстафет (исторических, географических, литературных, математических и т.п.)

\section{Лекционное занятие 6-ое.}

Тема: Массаж при детских церебральных параличах - достижения практики ЛФК.

План:

1. Массаж, как средство борьбы с разного рода последствий от заболеваний (церебральный паралич, полеомиэлит и др.);

2. Методика использования двигательных действий при занятиях послецеребрального паралича.

3. Некоторые практические рекомендации для учитерей и других специалистов спортивной деятельности.

\section{Литература:}

1. Лечебный массаж. В кн:А.Н. Жищенко - М., 2009, стр.91.

2. НасибулинаТ. В. Организация занятий адаптивной физической культурой с детьми с ограниченными возможностями здоровья/Сыктывкар,2016. [1] Физкультура для детей с OB3 // Корпорация российский учебник URL: https://rosuchebnik.ru/material/fizkultura-dlya-detey-s-ovz/ (дата обращения 01.03.2019). [2]

3. Подвижные игры для детей с ОВ3 // Социальная сеть работников образования URL: https://nsportal.ru/ blog/nachalnaya-shkola/all/2014/02/25/podvizhnye-igrydlya-detey-s-ovz(дата обращения 01.03.2019). [3]

4. Методика проведения занятий по адаптивной физической культуре с детьми, имеющими отклонения в состоянии здоровья // GYBERLENINKAURL: https:/ cyberleninka.ru/article/n/metodika-provedeniya-zanyatiypo-adaptivnoy-fizicheskoy-kulture-s-detmi-imeyuschimi- 
otkloneniya-v-sostoyanii-zdorovya (дата обращения 01.03.2019). [4]

5. Горючев, Д. В. Адаптивная физическая культура для детей с ограниченными возможностями здоровья / Д. В. Горючев. - Текст : непосредственный // Молодой ученый. — 2019. — № 11 (249). — C. 266-268. — URL: https:// moluch.ru/archive/249/57236/ (дата обращения: 10.10.2020.

Адаптивная физическая культура является составной частью медицинского восстановления детей с отклонениями в здоровье, способ регулярной функциональной терапии, который использует физические упражнения для сохранения телесно-двигательных возможностей ребенка, открытия его внутренних резервов в лечении заболевания, которое было вызвано вынужденной гиподинамией. Ключевые слова: адаптивная физическая культура, здоровье, ребенок, ограниченные возможности здоровья, упражнения, развитие. Адаптивная физическая культура - область общей физической культуры.

Главная цель адаптивной физической культуры- максимальное развитие жизнеспособности человека, который имеет устойчивые отклонения здоровья, благодаря организации постоянного режима функционирования его телесно-двигательных возможностей и духовного состояния, их развития для того, чтобы ребенок мог состояться как индивидуально и социально значимый субъект. [1]

Совокупность методов проведения адаптивной физической культуры значительно отличается, что связано с аномальным психофизиологическим развитием ребенка. [1] Для построения процесса физического развития детей с ограниченными возможностями здоровья необходимо быть осведомленным о состоянии здоровья ученика, его физических, психических и личностных индивидуальных особенностях, в связи с тем, что первоначальным условием начала образовательного процесса является характеристика ученика. Нужно отметить, что по классификации болезней категория детей с ограниченными возможностями здоровья очень разнообразная. В том числе важными факторами являются возраст, степень тяжести, медицинские показания по сопутствующим заболеваниям и вторичным отклонениям, структура протекания болезни.

Средствами адаптивной физической культуры являются физические упражнения, природные и гигиенические факторы. Главную роль занимают физические упражнения, благодаря которым учитель производит направленное воздействие на ребёнка с ограниченными возможностями здоровья, решает вместе с ним развивающие, коррекционные, воспитательные, оздоровительные и профилактические задачи. В следствие многоповторного выполнения упражнений ученик улучшает свою физическую форму, совершенствует движения и развивает новые двигательные возможности. Также результат от регулярных физических упражнений способствует большому количеству изменений биологических структур и функций. Человек с ограниченными возможностями здоровья в любом возрасте может прибегнуть к физическим упражнениям, и они будут давать положительный результат, но особенно сильно адаптивная физическая культура влияет на растущий организм.

Физические упражнения имеют ряд преимуществ [2]: Развитие и укрепление опорно-двигательной системы, улучшение тонуса и эластичности мышц, увеличение силы и укрепление суставов. Стимулирование кровоо- 
бращения и обмена веществ. Увеличение работоспособности мозга и стрессоустойчивости, Развитие сенсорных функций.

Адаптивная физическая культура способствует развитию интересов и потребностей, воспитывает характер, формирует поведение и волю благодаря тому, что на уроках физической культуры упражнения наполнены целенаправленными действиями, сопряжено с множеством психических процессов, с регулированием качества движений, с умственной деятельностью и эмоциональной реакцией.

Выделяют эффективный способ проведения занятий физической культуры для детей с ограниченными возможностями здоровья, который развивает координацию, волевую и психическую составляющую характера ученика, это игра. Люди всех возрастов с радостью вовлекаются в игры, потому что именно игра может удовлетворить потребности человека в эмоциях, досуге, общении и активной деятельности, а также является способом самовыражения.

При выборе игр необходимо учитывать индивидуальные физические особенности, двигательные возможности группы, а также возраст. Доказано, что игровой процесс является не только развлечением, но и способом повышения телесно-двигательной активности, развития умственной деятельности и выражения эмоций. [3]

Главным принципом в проведении физической культуры для учеников с ограниченными возможностями здоровья является индивидуальный подход, исходя из которого распределяются нагрузки.

Таким образом, благодаря организации постоянных занятий адаптивной физической культурой заметно улуч- шается психофизиологическое состояние детей с ограниченными возможностями здоровья, а также, что не менее важно происходит приобщение учеников к необходимым им физическим упражнениям и способностью управлять своим психофизиологическим состоянием.

Анализируя процесс физического воспитания в класcax, где обучаются дети с ОВ3 (ограниченными возможностями здоровья), надо отметить, что специфической направленностью в работе с этой категорией детей является ее коррекционно-компенсаторная сторона, в том числе и процесса физическоговоспитания.

Наблюдения и практический опыт показывают, что школьники с OB3 нуждаются в повышении двигательной активности. Исправление нарушений физического развития, моторики и расширение двигательных возможностей таких детей являются главным условием подготовки его к жизни.

Эффективность физических упражнений для коррекции нарушений моторики и недостатков физического развития подчеркивается в работах многих ученых (П.П. Павлов, П.Ф. Лесгафт, В.В. Ториневский, Л.В. Запорожец и др.)

Коррекционная работа, осуществляемая адаптивной физической культурой, и, представляющая собой систему различных мероприятий, направленных на исправление недостатков в развитии человека, является основой социальной реабилитации и поэтому между понятиями физической и социальной реабилитации существует диалектическая взаимосвязь. Здесь опорными становятся принципы, разработанные Л.С.Выгодским (опора на сохраненные возможности, зоны ближайшего развития), а также методы деятельностного подхода, деловых игр, 
коллективного способа обучения, учение о приоритетном развитии высших психических функций, об укрупнении дидактических единиц, одновременном развитии всех учащихся, личностно развивающем образовании.

При организации уроков физической культуры:

- выполнение упражнения по частям, изучая каждую фазу движения отдельй, а затем объединяя их в целое;

- выполнение движения в облегчённых условиях;

- выполнение движения в усложнённых условиях (например, использование дополнительных)

- использование сопротивлений (упражнения в парах, с резиновыми амортизаторами и т.д.),

- использование ориентиров при передвижении (звуковые, осязательные, обонятельные и др.),

- использование имитационных упражнений,

- подражательные упражнения,

- использование при ходьбе, беге лидера,

\section{Лекционное занятие 7-ое.}

Тема: Современное ЛФК в действии.

Значение ЛФК в профессиональной подготовке специалистов ФКиС.

\section{План:}

1. Современная ЛФК в практической деятьльности специалиста ФКиС;

2. ЛФК Учебный курс профессиональной подготовки и повышения квал

3. Педагог по лечебной физкультуре предназначен для освоения навыков и методик, для проведения процедур ЛФК, профилактики и реабилитации пациентов, выработки комплексов физических упражнений в борьбе с разного рода недугов

\section{Лuтература:}

1. Пересветов Н.Н. К здоровью - через туризм. Из опыта работы Зап.-Каз. Областного центра туризма и экологии. Методические рекомендации для педагогов дополнительного образования. - Уральск: Полиграфсервис, 2000.

2. Аяган Б.Г. Наша задача - быть объективными исследователями эпохи. В сб: «Актуальные проблемы изучения истории независимого Казахстана. - Астана. Институт истории государства, 2008, стр. 27.

Профессиональная физическая подготовка по ЛФК специалистов должна включать изучение основ анатомии, биомеханики и физиологии человеческого организ- 
ма, умение применять разнообразные психологические подходы и методики для работы с людьми всех возрастов, включая маленьких детей и людей в преклонном возрасте.

Особенности работы со слабослышащими детьми дошкольного возраста

Слух, наприпример, а это доказано, имеет огромное значение для развития человека. У ребенка, лишенного слуха, познание окружающей действительности крайне затруднено. Ребенок р+ приобретенные.

Среди причин, вызывающих приобретенные недостатки слуха, основное место занимают инфекционные заболевания, перенесенные в грудном и раннем детстве. Так мировая практика показывает, что на 100000 новорожденных рождается 3-5 детей с врожденными нарушениями слуха, а к 10 годам подрастания просматривается достаточно большое количество учащихся, которые нуждаются в специальном использовании физических упражнений в интересах образования и воспитания детей.

Глухота в раннем детстве бывает абсолютной в исключительных случаях. Обычно остатки слуха позволяют воспринимать отдельные очень громкие, резкие и низкие звуки, однако разборчивое восприятие речи обычной громкости невозможно.

Отдельную группу, в отношении формирования речи и ее восприятия составляют позднооглохнувшие. У таких детей может быть разная степень нарушения слуха и также разный уровень сохранности речи. При этом у рано оглохнувших детей резко ограничена возможность овладения словесной речью, что приводит в последствии к глухонемоте, так как ребенок не может разборчиво вос- принимать чужую и собственную речь, подражать окружающим.

Глубокое и стойкое нарушение слуха оказывает отрицательное влияние на психическое, физическое и личностное развитие ребенка. Главной и наиболее трудной задачей воспитания и обучения глухих детей является формирование у них словесной речи и речевого мышления.

В отличие от глухих детей, слабослышащие обладают остаточным слухом, что можно достаточно эффективно использовать в процессе занятия физической культурой, для общения с окружающими и познания мира. Здесь также возможна корректировка, набор и овладевание речевым запасом. При применении адаптивных методик физического развития и работе с такими детьми надо также учитывать и степень снижения слуха (легкая, умеренная, значительная или тяжелая) и длительность этого снижения.

Речь слабослышащих имеет свои особенности. Ребенок какие то звуки не улавливает совсем, другие не воспринимает как здоровые люди на 100\%. Так он искаженно слышит слова, и искаженно их воспринимает, что в дальнейшем затрудняет и произношение и написание. Дети легко путают предметы и действия и близкие по звучанию слова, что также влияет на их неспособность заниматься в обычных школах. При этом своеобразие речи слабослышащих детей следует рассматривать не столько как недостаточность, сколько как процесс замедленного поступательного развития речи, подчиненного особым закономерностям.

Зачастую окружающие речевые затруднения слабослышащих детей воспринимают как рассеянность, невни- 
мание и даже как интеллектуальная недостаточность. Ребенка зачастую ругают, а иногда и наказывают за упрямство, неграмотность, лень, не понимая истинных причин такого поведения. В результате такого неправильного отношения к ребенку вызывает у него отрицательное поведение (нерешительность, плаксивость, замкнутость, неуверенность, раздражительность, негативизм). Поэтому обязательным условием успешного развития слабослышащих детей является правильное организованное воспитание, где большую роль уделяют физическому развитию.

В работе с такими детьми важно выработать и использовать имеющийся уровень речи и слуха для общения, на основе которого строится вся коррекционная работа. Это может быть язык жестов и мимики, который находит педагог совместно с родителями. Необходимо обогащать сенсорное восприятие малыша, включая в совместную деятельность любой способ опосредования, стараться находиться в зоне его видимости, попутно громко и четко произнося все действия.

Также важно включать такого ребенка во взаимодействие со сверстниками. Смысл коррекционной работы для ребенка с нарушением слуха заключается в том, чтобы создать такие условия для его развития и обучения, которые позволят расширить и качественно изменить доходящие до него внешние воздействия, изменить количественный и качественный состав речи, то есть заменить акустические воздействия на равные им по значению. Здесь также кроме физических упражнений и адаптивной гимнастики и массажей, необходимо обучать ребенка чтению, научить читать с губ, жестов, выполнять действия по подражанию, использовать символы - опоры.
Так как работа по развитию слухового восприятию и обучению произношения образует целостную взаимосвязанную систему, специальные формы работы на всех этапах обучения оказываются едиными. Это также индивидуальные занятия по развитию слухового восприятия и обучению произношения слов. Очень хорошо использовать методику и систему игр. Здесь также надо выделить важность занятий на музыкальных инструментах, где осуществляется систематическая работа по развитию и корректировки слухового восприятия звуков и музыки. Данная работа имеет большое значение как для эмоционального, так и эстетического развития слабослышащих детей.

Разнообразие методических приемов при обучении различию и опознаванию речевого материала имеет важное значение для детей дошкольного возраста, и превращает слуховые тренировки в интересную для ребенка познавательную игру.

Особенности работы со слабослышащими детьми дошкольного возраста

Слух имеет огромное значение для развития человека. У ребенка, лишенного слуха, познание окружающей действительности крайне затруднено. Ребенок не сможет самостоятельно научиться говорить, так как не воспринимает речь, не слышит звуковых образцов для подражания..

Нарушения слуха могут быть врожденными и приобретенными. Врожденные нарушения слуха встречаются значительно реже (в 25\% случаев), чем приобретенные.

Среди причин, вызывающих приобретенные недостатки слуха, основное место занимают инфекционные заболевания, перенесенные в грудном и раннем детстве. 
Так мировая практика показывает, что на 100000 новорожденных рождается 3-5 детей с врожденными нарушениями слуха, а к 10 годам подрастания просматривается достаточно большое количество учащихся, которые нуждаются в специальном использовании физических упражнений в интересах образования и воспитания детей.

Глухота в раннем детстве бывает абсолютной в исключительных случаях. Обычно остатки слуха позволяют воспринимать отдельные очень громкие, резкие и низкие звуки, однако разборчивое восприятие речи обычной громкости невозможно.

Отдельную группу, в отношении формирования речи и ее восприятия составляют позднооглохнувшие. У таких детей может быть разная степень нарушения слуха и также разный уровень сохранности речи. При этом у рано оглохнувших детей резко ограничена возможность овладения словесной речью, что приводит в последствии к глухонемоте, так как ребенок не может разборчиво воспринимать чужую и собственную речь, подражать окружающим.

Глубокое и стойкое нарушение слуха оказывает отрицательное влияние на психическое, физическое и личностное развитие ребенка. Главной и наиболее трудной задачей воспитания и обучения глухих детей является формирование у них словесной речи и речевого мышления.

В отличие от глухих детей, слабослышащие обладают остаточным слухом, что можно достаточно эффективно использовать в процессе занятия физической культурой, для общения с окружающими и познания мира. Здесь также возможна корректировка, набор и овладевание ре- чевым запасом. При применении адаптивных методик физического развития и работе с такими детьми надо также учитывать и степень снижения слуха (легкая, умеренная, значительная или тяжелая) и длительность этого снижения.

Речь слабослышащих имеет свои особенности. Ребенок какие то звуки не улавливает совсем, другие не воспринимает как здоровые люди на $100 \%$. Так он искаженно слышит слова, и искаженно их воспринимает, что в дальнейшем затрудняет и произношение и написание. Дети легко путают предметы и действия и близкие по звучанию слова, что также влияет на их неспособность заниматься в обычных школах. При этом своеобразие речи слабослышащих детей следует рассматривать не столько как недостаточность, сколько как процесс замедленного поступательного развития речи, подчиненного особым закономерностям.

Зачастую окружающие речевые затруднения слабослышащих детей воспринимают как рассеянность, невнимание и даже как интеллектуальная недостаточность. Ребенка зачастую ругают, а иногда и наказывают за упрямство, неграмотность, лень, не понимая истинных причин такого поведения. В результате такого неправильного отношения к ребенку вызывает у него отрицательное поведение (нерешительность, плаксивость, замкнутость, неуверенность, раздражительность, негативизм). Поэтому обязательным условием успешного развития слабослышащих детей является правильное организованное воспитание, где большую роль уделяют физическому развитию.

В работе с такими детьми важно выработать и использовать имеющийся уровень речи и слуха для общения, 
на основе которого строится вся коррекционная работа. Это может быть язык жестов и мимики, который находит педагог совместно с родителями. Необходимо обогащать сенсорное восприятие, включая в совместную деятельность любой способ опосредования, стараться находиться в зоне его видимости, попутно громко и четко произнося все действия.

Также важно включать такого ребенка во взаимодействие со сверстниками. Смысл коррекционной работы для ребенка с нарушением слуха заключается в том, чтобы создать такие условия для его развития и обучения, которые позволят расширить и качественно изменить доходящие до него внешние воздействия, изменить количественный и качественный состав речи, то есть заменить акустические воздействия на равные им по значению. Здесь также кроме физических упражнений и адаптивной гимнастики и массажей, необходимо обучать ребенка чтению, научить читать с губ, жестов, выполнять действия по подражанию, использовать символы - опоры.

Так как работа по развитию слухового восприятию и обучению произношения образует целостную взаимосвязанную систему, специальные формы работы на всех этапах обучения оказываются едиными. Это также индивидуальные занятия по развитию слухового восприятия и обучению произношения слов. Очень хорошо использовать методику и систему игр. Здесь также надо выделить важность занятий на музыкальных инструментах, где осуществляется систематическая работа по развитию и корректировки слухового восприятия звуков и музыки. Данная работа имеет большое значение как для эмоционального, так и эстетического развития слабослышащих детей.
Разнообразие методических приемов при обучении различию и опознаванию речевого материала имеет важное значение для детей дошкольного возраста, и превращает слуховые тренировки в интересную для ребенка познавательную игру. 


\section{Лекционное занятие 8-ое.}

Тема: Восточно-оздоровительные системы и нетрадиционные формы физического воспитания

в Казахстане: история и современность.

План:

1. Оздоровительные системы и их использование в практике воспитательно-образовательной работы с населением, учащимися.

2. Оздоровительные системы Древнего Востока.

3. Особенности методики Восточных воспитательнообразовательных, оздоровительных систем и современность.

a) Система Йога.

б) Система Цыгун.

в) Система Тайцзы-Цюань.

г) Система У-шу.

4. Система У-шу, как научная, воспитательнообразовательная и оздоровительная дисциплина в учебных заведениях современного Китая.

5. Рекомендации по использованию Восточных систем оздоровления и воспитания в профессиональнопедагогической подготовке специалистов ФКиС.

Лuтература:

1. Лиин Д. Оздоровительные упражнения древнего Китая / Д. Лин. - М. : Феникс, 2006; 2. Пересветов Н.Н. Традиционные и нетрадиционные методы оздоровления и гармонизация организма. В кн Экология. Избранные лекции. - Уральск, Зап.-Каз. институт «Евразия», 2004, стр. 67-71; 3. Крамер Н. Ю. Оздоровительные системы Востока / Н. Ю. Крамер. - М. : Омега Медиагрупп, 90
2009; 4. Венугопалан Р. Тибетская энциклопедия древних методик оздоровления / Р. Венугопалан. - М.: АСТ Астрель, 2008; 5. Смирнов, А. В. Русский цигун / А. В. Смирнов. - М. Диля, 2007; 6. Скотт Д. А., Штанга-йога / Д. Скотт. - М. : Фаир, 2007; 7. Бах Б. Оздоровительные дыхательные системы / Б. Бах. - М.: АСТ Сталкер, 2008; 8. Утицын О.Б. и др. Центр изучения оздоровительных систем Дальнего востока / О. Утицын. - М.1989; 9. Вэй Синь, У. Тайцзи-цигун и могун / У. Вэй Синь. - СПб. : Нева, 2005; 10. Белая-Швед Т. Самоучитель по йоге / Т. Белая-Швед. - Ростов Н /Д. : Феникс, 2009; 11. Менхин Ю. В. Оздоровительная гимнастика: теория и методика / Ю. В. Менхин, А. В. Менхин. - Ростов Н /Д : Феникс, 2002 ; 12. Шифферс М. Простая йога для начинающих / М. Шифферс. - М. : Прагматика, 2007; 13. Салов В.Ю. Кульназаров А.К.и др. Теория и методика здорового образа жизни. Учебное пособие, - Алматы, 2004; 14. Боевые искусства Шаолиня. Вып. 2. Стиль обезьяны. - М., ФиС, 1991; Есенгалием М.Т. Боевая гимнастика для пальцев. - Уральск, Оптима, 2011; Присяжнюк М. и др. Захисти себе. - Житомир, 2007 (На украинском языке).

Из современных научных источников хорошо известно (Жолдак, В.И., Салов В.Ю.,Собянин Ф.И. и др.), что здоровье - важнейший показатель любой социальной системы общества, государств, любого живого организма. Есть сведения, что некоторые животные и птицы живут достаточно долго (Черепаха, Слон, Ворон, Орел, земноводные Рептилии и др. ), а для человека, в некоторых странах и 50 лет является пределом. Естественно возникает вопрос: - А в чем секреты долгожительства? Применительно к человеку здоровье является мерой вы- 
сокой духовной культуры, показателем качества жизни развитых государств мира. Есть официальные данные, что в ряде стран Европы и Азии продолжительность жизни людей достаточно высока и достигает в среднем порою 80 и более лет (Япония, Китай, Швейцария, США, Израиль, Россия и др.).

В последние десятилетия наряду с ощутимым положительным влиянием научно-технического прогресса на обеспечение современного здравоохранения, а это очевидно, продолжительность жизни людей продолжает расти. И главная заслуга в этом - научно-технический прогресс, научные знания в области гигиены и здравоохранения, растущий культурный уровень населения.

Имеются факты и отрицательного влияние технического прогресса на здоровье человека (Гиподинамия и нарастание объема психической напряженности, чрезмерная умственная деятельность. Загазованность воздуха и нехватки кислорода, выбросы радиации и постоянные региональные войны. Другие факторы. Влияет на продолжительность жизни человека и, например, нехватка пресной воды, наступление пустынь, уничтожение лесов. Влияют на продолжительность жизни людей и уменьшение плодородия почвы, а также нарастание количества свалок бытовых отходов жизнедеятельности и многое другое.).

В связи со всем этим возрастает потребность населения и научной мысли в поиске наиболее эффективных средств и методов для улучшения и сохранения собственного здоровья человека. Увеличения продолжительности активной жизни человека, особенно, ее деятельного компонента (Пересветов Н.Н., Салов В.Ю., Кульназаров А.К. и др.)
Несмотря на скептическое отношение многих людей к «Древним оздоровительным практикам», Восточные системы профилактики, лечения и оздоровления организма человека приобретают в наши дни все больше сторонников. Оздоровительные практики древних, несомненно, эффективны, но лишь в том случае, если применяются грамотно, с учетом современного научно-технического, педагогического опыта и обязательно специалистами высокого класса.

Методика и практика использования Восточных оздоровительных систем не является обязательной дисциплиной при подготовке специалистов в области физической культуры и спорта, а жаль! Но она совершенно не исключает возможности преподавания на специальных факультетах в качестве ознакомительных факультативов, элективных лекционных и семинарских курсов. Знание оздоровительных систем, например, Древнего Востока для специалистов ФКиС, по нашему мнению, крайне желательно, как с профессиональной, так и научнопрактической точек зрения.

Итак. Целью данного сообщения является - ознакомление будущих специалистов ФКиС (будущих учителей и спортивных тренеров, пропагандистов ) с самой идеей создания Древневосточных оздоровительных систем, а на этой основе повышения компетенции учителей и спортивных тренеров, их профессиональной грамотности и педагогического мастерства.

\section{Задачи сообщения:}

1. Познакомить будущих специалистов ФКиС с самой идеей создания оздоровительных систем Древнего Востока;

2. Профессионально рассмотреть и дать принципи- 
альную оценку методике использования оздоровительных систем Древнего Востока в практике профессионального физического воспитания и образовани;

3. Внести обоснованные предложения по использованию полученных знаний для совершенствования профессиональной подготовки современных специалистов.

Ожидаемый результат - Научная гипотеза впитала в себя мысль, которая сводится к тому, что освоение систем воспитания и оздоровления средствами систем Древнего Востока позволит, хотя бы частично, повысить качество жизни современных людей, а вместе с этим и профессиональную компетенцию, профессиональное мастерство специалистов ФКиС.

Вопрос: - Что представляют собой оздоровительные системы и какова их роль в жизни современного общеcmвa?

Оздоровительные системы - это системы знаний и практического опыта по использованию оригинальных методик, позволяющих обеспечить формирование крепкого здоровья человека, добиться невосприятия организмом, разного рода, простудным заболеваниям.

Оздоровительные системы начали формироваться с момента зарождения человеческих цивилизаций и естественным образом входят в культуру всего человечества. Известные оздоровительные системы условно можно разделить на современные и нетрадиционные:

К современным системам оздоровления можно отнести систему Кеннета Купера (США), систему Парфирия Корнеевича Иванова и Николая Михаиловича Амосова (Россия), системы закаливания и «Моржевания»(В.Ю. Салов, А.К. Кульназаров и др). Или, например, систему атлетизма Арнольда Шварццнеггера, а также различные системы шейпинга (Т.И. Клименко и др.), системы циклических двигательных действий - «Оздоровительная ходьба», «Бега трусцой - (Бег от инфаркта)», системы прогулочных терренкуров, системы «Русских бань», Скандинавской системы продолжительной ходьбы с лыжными палками, а также продолжительного плавания, ходьбы на лыжах, езды на велосипеде, дыхательные гимнастики и другие.

Особенно следует напомнить о содержании оздоровилельной системы - «Детка» разработанной в первой половине XX века, народным целителем из России Парфирием Корнеевичем Ивановым. Он завещал:

1. Два раза в день купайся в холодной природной воде, чтобы тебе было хорошо. Купайся в чем можешь: в озере, речке, воной, принимай душ или обливайся. Это твои условия. Горячее купание всегда завершай холодным;

2. Перед купанием или после него, а если возможно то и совместно с ним, выйди на природу, встань босыми ногами на землю, а зимой на снег, хотя бы на одну-две минуты. Вдохни через рот несколько раз воздух и мысленно попроси себе и пожелай всем людям здоровья;

3. Не употребляй алкоголь и не кури;

4. Старайся хотя бы раз в неделю полностью обходиться без пищи и воды. Например, с пятницы 18 - 20 часов до воскресенья 12 часов... Итак, 12 заповедей народного целителя, в числе которых (10-ая заповедь). Освободи свою голову от мыслей о болезнях, недомоганиях, смерти. Это твоя победа!

Достаточный авторитет среди народа приобрели и другие, например, нетрадиционные систем оздоровле- 
ния: Системы оздоровительных пищевых диет (арбузная, яблочная, молочная и др.) , вегетарианство, профилактическое голодание, система сыроедения, а также системы Дзю-до, Кара-тэ-до, У-шу, Цигун и др.

Нетрадиционные оздоровительные системы Древнего Востока пришли к нам, как свидетельствует литература, из стран с непрерывно развивающейся древней культуры - Тибета, Египта, Индии, Японии и Китая;

Современные оздоровительные системы формируются и в странах сравнительно молодой культуры. Формирование происходит на основе системного, целостного подходов. Например, с помощью бывшей Советской системы оздоровления и воспитания - «Готов к труду и обороне» - «ГТО», современной системы Президентских тестов в Казахстане, скандинавской система оздоровления - продолжительная спокойная ходьба с лыжными палками и другие.

Из этого следует заметить, что во всех оздоровительных системах важное место отводится роли специалиста - воспитателя, которым может быть только высокоразвитая, широко образованная личность. Личность, имеющая базовое профессиональное образование, прошедшая свой собственный путь к здоровью, обладающая большим объемом профессиональных знаний и практических умений, навыков. Специалиста, хорошо знающего основы анатомию, биохимии и физиологию человека, теорию и методику оздоровительной работы, лечебную физическую культуру (ЛФК), восстановительный массаж и врачебный контроль (ВК). Специалиста, успешно работающего, например, с людьми разного возраста и пола. С людьми, имеющими физические и психические недостатки (Без рук, без ног, слепых, глухих, умственно отсталых, с девиантным поведением и т.п. ). Владеющих, например, системой воспитания и подготовки атлетов для участия в международных спортивных соревнованиях - Паралимпиадах современности и т.д..

Доказано, что при использовании той или иной оздоровительной системы большую роль выполняет выбор методики.

Какую бы методику вы ни избирали, смысл должен остается один: «В здоровом теле - здоровый дух!». В процессе оздоровительных занятий необходимо следовать основным принципам:

- чтобы чувствовать себя хорошо, физическое тело человека следует держать в постоянном активном состоянии;

- чтобы физическое тело стало активным и здоровым, нужно постоянно поддерживать его в тонусе: разминать, массировать, тренировать, закаливать, т.е. заставлять работать мышечную ткань, а значит, и обновлять её;

- для этой цели годится любой вид физической активности, который заставляет работать основные мышечные группы или все мышцы, доставляя удовольствие и не являясь помехой в повседневной жизни (ходьба, медленный бег, плавание, велосипед, лыжи и т.п.);

- физические упражнения должны быть регулярными и строго дозируемыми. Учитывать пол и возраст, уровень подготовленности человека;

- методики использования физических упражнений, могут быть составлены и самостоятельно, с учетом индивидуальных особенностей и личных пожеланий. Это может быть даже предпочтительнее, потому что выполняются они с большим удовольствием и воздействуют комплексно - как на тело, так и на общее самочувствие, 
настроение (Подскоки на скакалке, приседания и наклоны туловища, работа на тренажерах, водный шейпинг, атлетизм и др.);

- индивидуальные методики могут быть созданы на основе восточных или смешанных оздоровительных систем, однако не следует забывать, что они должны быть составлены профессионально, а значит, грамотно.

Большинство оздоровительных систем, как свидетельствуют литературные данные, направлены на то, чтобы восполнить недостаток двигательной активности и правильно распределить нагрузку по основным группам мышц, внутренним органам (сердцу, легким, системе пищеварения и выделения, нервной системе и т.п.).

\section{1. Особенности Восточных оздоровительных систем.}

Восточные системы физических упражнений, используемые, как правило, для оздоровления впитали в себя многовековые традиции и богатый опыт многих поколений, позволяющих познать и использовать скрытые резервы организма человека. Системы, способные развивать его психо-физиологические качества в гармонии с окружающей средой.

К восточным методикам и нетрадиционным оздоровительным системам можно отнести всевозможные разновидности индийской Йоги (Хатха Йога, Раджа Йога и др.), китайского Цигуна, Тайцзи-цюаня, Даосизма, Медитации и Тибетской медицины. Многие другие учения, пришедшие к нам из стран Древнего Востока или возникшие в результате взаимодействия Восточных и Западных оздоровительных систем современности.

Отличительными особенностями Восточных оздоровительных систем являются их: религиозно- философская основа; ритуальность и образность оформления занятий; попытка глубокого осмысления роли телодвижений; строгая регламентация двигательных действий, поз и их соединений в соответствии с канонами конкретной системы. Использование приемов психической и физической саморегуляции, медитации.

Преимущество восточных оздоровительных методик состоит в том, что они соединяют в себе не только приемы физической тренировки, массажа и разминания тела, но и основательной «работы» с внутренней энергетикой человека.

\section{2. Система физических упражнений Йога}

Термин «Йога» (в переводе с Древнеиндийского, означает: «связь, единение, сосредоточение, обуздание»). Этот термин часто встречается в философских текстах древних ученых. Текстах, восходящих еще к традициям IX-VIII вв. до н.э. В самом общем смысле Индийская Йога - это теория и методология управления психикой и психофизиологией состояний человеческого организма. В этом смысле Йога представляет собой неотъемлемую часть всех философских и религиозных систем древней и средневековой Индии. Йога, является важнейшим средством реализации этических и религиозных идеалов, высшей из которых - полное освобождение человека от материального существования.

Всеобъемлющее йогическое мировоззрение невероятно трудно свести к нескольким кратким положениям, однако, несмотря на свои «сложности» и многогранность, Йога пользуется огромной популярностью и давно уже стала частью не только Индийской, но и Европейской культуры. Йога преподается в современных индийских общеобразовательных школах и университетаю. Как и 
все Восточные системы оздоровления, Йога включает в себя не только комплексы упражнений, но и философию отношения к жизни и к своему телу, как к вместилищу души, жизненного духа.

Согласно учению Йоги, все наши болезни, нарушения жизнедеятельности, недомогания являются следствием порочного образа жизни, присутствия вредных привычек, нарушения рационов питания, неправильных представлений о действиях, имеющих большое значение в жизни человека (общение человека с человеком, человека с окружающей природой, болезнями и недомоганиями).

Болезни - это, по мнению специалистов Йоги, результат нарушения функционирования жизненных систем организма. Нарушений, вызванных внутренним дисбалансом, который, как правило, возникает вследствие определенных ошибок, совершаемых человеком (недоедание и переедание, переутомление и недосыпание, систематическое безделье -«болдение»). Итак, причина болезней - ошибки жизнедеятельности, а лечение - исправление этих ошибок. Таким образом, сам человек ответственен как за возникновение, так и за лечение болезней.

Йоговский метод лечения включает три компонента: 1) правильное питание; 2) правильные практические занятия двигательной деятельностью, например, Йогой; 3) правильные представления о вещах, которые имеют не главное значение в жизни человека. И если соблюдать все эти правила то, болезни исчезают сами по себе. По крайней мере, так утверждают Учителя Йоги и их последователи.

Но вполне правомерен и такой вопрос: - $A$ что такое «правильные» и «неправильные» компонентыз? Как опре- делить «правильно» ли человек смотрит на те или иные вещуи, правильно ли дышит, двигается и, наконец, правильно ли относится к другим людям, (человек к человеку), правильно питается, достаточно ли спит?

Последователи Йоги убеждены, что, например, неправильное питание может свести на нет все усилия по освоению Йогических практик. От того, что вы едите, многое зависит. Многие люди, практикующие Йогу, вегетарианцы. Но «плюсы» и «минусы» вегетарианства - это отдельная тема разговора. Об этом еще будет сказано.

Сегодня лишь можно заметить, что основной принцип подбора пищевых продуктов - поддержание в организме жизненного равновесия, которое тесно связано с исключением из рациона тех компонентов, которые считаются вредными. Согласно Йоги, главными компонентами пищевого рациона почти для всех людей являются следующие продукты: фрукты, салаты, листья огородных растений и культур, овощи, пшеничный хлеб, стручковые растения (горох, бобы, фасоль) и другие. Для не вегетарианцев допускается в некоторых случаях употребление рыбы и печени, но мясо и мясо птицы, полностью должны быть исключены.

Как бы ни был составлен пищевой рацион, занимающиеся должны соблюдать определенные принципы питания: есть спокойно медленно, хорошо пережевывая пищу и съедать только 80 - 85\% желаемого количества пищи, т.е. вставать из-за стола слегка голодным. Принимать же пищу последний раз не менее чем за 2- 2,5 часа до отхода ко сну. В процессе питания не употреблять очень горячую, острую, жареную, жирную, переперченную пищу. Выпивать не более 1-2 чашек кофе в день, а лучше вообще отказаться от этого напитка и система- 
тически заниматься двигательной деятельностью. Избегать употребления алкоголя и табака. Правильно питаясь и занимаясь Йогой, можно, по мнению индийских специалистов, излечиться от многих болезней, сохранить телесную красоту, молодость и здоровье.

2.3.Оздоровительная система Цигун

Многовековой опыт китайской народной медицины, обобщенный знаменитыми врачами древности, воплотился в систему оздоровительной гимнастики цигун. Цигун, можно определить как искусство тренировки Ци (жизненной энергии) и разума (психического сознания). Китайский иероглиф «Ци» означает дыхание, а «Гунн» - процесс тщательной проработки сознания. В данном случае непрерывное регулирование дыхания и положения тела, контроль за которыми осуществляет сознание, обязательно дадут ожидаемые положительные результаты. Сами китайцы определяют цигун, как одно из драгоценных наследий в сокровищнице традиционной китайской медицины, великое достояние китайской медицинской литературы. Цыгун - оздоровительную и общеукрепляющую систему с отличительными национальными чертами. Гимнастика цигун - совершенно уникальная система тренировки, как тела, так и психики. Тренировки организма посредствам взращивания жизненной энергии и жизненного духа человека.

Цигун - достаточно сложный и многообразный комплекс упражнений, представляющих единство искусства дыхания и движения, который и помогает сохранить здоровье, бодрость, спокойствие, легкость движений, остроту восприятия и целостность окружающего мира. Система, которая позволяет справляться со многими заболеваниями органов пищеварения, дыхания, сердечно- сосудистой системы (ССС), органов выделения. Особенно полезен этот вид гимнастики для людей, не имеющих возможности уделять много времени активным занятиям двигательной деятельности или спортом.

Регулярные занятия оздоровительной гимнастикой цигун позволяет улучшить здоровье, помогает постоянно находиться в хорошем настроении, научают управлять своими эмоциями, быстро восстанавливаться после напряженного трудового дня, продолжительного нервного напряжения.

Заниматься гимнастикой цигун - значит тренировать не только энергию Ци, но и собственное сознание, которое при этом направляет поток Ци по сети каналов для стимуляции и усиления функциональной активности внутренних органов, увеличения запасов внутренней энергии. Напомним, что управление потоками энергии помогает не только излечивать болезни, но и сохранить крепкое здоровье, бодрость, активную творческую деятельность. Кроме того, человек может выбирать тип и виды гимнастики с учетом характера своего заболевания, возраста, пола, телосложения и других индивидуальных особенностей.

В настоящее время существует множество школ цигун, как в Китае, так и за его пределами (Западная Европа и США).

Выделяют несколько форм гимнастики цигун: статическую, динамическую и смешанную.

Статический цигун (изингун, «статическая работа») характеризуется сидячими, лежачими и стоячими позами, внешне статичными. В статическом цигуне вся работа происходит «внутри» организма, где работают лишь дыхание и мысль, тело при этом кажется неподвижным. 
Применяются такие методы как успокоение, релаксация, концентрация, правильное дыхание. Делается упор на внутреннее закаливание тела. Однако, будучи методом тренировки, статические виды цигуна не обходится совсем без движений.

Динамический иигун (дунгун, или «динамическая работа»). Этот вид оздоровительной работы использует приемы движения конечностей в сочетании с работой сознания и энергии Ци, а также широко практикует самомассаж и другие приемы с целью тренировки внутренних органов. Укрепления костной и мышечной тканей, гибкости, поддержания эластичности кожи. Этот вид гимнастики предполагает движения, проявляющиеся вовне. Упражнения выполняются в условиях концентрации внимания и спокойного сознания. В процессе 24 занятий динамическим цигуном, занимающийся, совмещает внешнюю работу с телом и внутреннюю работу с энергией Ци.

Смешанные формы цицуна - это соединение приемов статического и динамического цигуна. Смешанный цигун базируется на «внешней динамичности и внутренней статичности», то есть «внешнем движении и внутреннем покое».

2.4. Оздоровительная система Тайцзи-иююань.

Тайцзи-цюань - одно из богатейших культурных наследий Древнего Китая. Принято считать, что учение Тайцзи-цюань возникло около 300 лет назад как воинское искусство, в основу которого легли принципы, изложенные в «Цюань цзин» («Книге бокса»). Этот трактат был написан знаменитым военным начальником, генералом XVI века Ци Зигуанем, который собрал и осмыслил, тщательно сравнил 16 стилей китайского бокса, широко распространенных в народе.

Несколько веков спустя, другой мастер воинских искусств - Ван Зонгуи связал новый стиль с классической философией Инь и Ян ( два противоположных, но взаимоувязанных принципа в природе, мужского и женского начала). Именно он то и дал этому стилю формальное название - «Тайцзи-цюань». Вскоре этот стиль начал распространяться по всему континентальному Китаю.

Как и в любой другой системе, в Тайцзи-цюань большое внимание уделяется позвоночнику, как органу движения. Позвоночнику, который следует всегда держать прямым. Нижний конец позвоночника, копчик, должен быть направлен немного вперед, а промежность поджата ягодицами, чтобы энергия Ци не уходила вниз, а поднималась по каналу, таким образом, чтобы замыкаться как микрокосмическая орбита. Дыхание, при выполнении упражнений, должно быть свободным. Движения, даже те, которые нужно выполнять быстро, должны быть плавными, свободным, легкими. Внимание, должно быть направлено на то, что происходит с телом. Формальное выполнение упражнений не приносит организму вреда, но и не несет оздоравливающего (терапевтического) эффекта. Выполнять движения следует легко и непринужденно, сохраняя устойчивость тела на всем протяжении занятий. Мышцы при этом должны быть расслабленными. Во время занятий Тайцзи-цюань, необходимы, гибкость и естественность. Передвигаться нужно легко и свободно, мягко.

2.5. УШУ, как научная и учебная дисциилина.

Система Ушу - национальное достояние Китая, традиционное народное искусство, включающее в себя гимнастическое, военное, оздоровительное и лечебное направ- 
ления.

Система Ушу не имеет аналогов в Мире. История создания ушу берет начало со 2-го тысячелетия до нашей эры. Как гимнастическая система, ушу насчитывает более нескольких сотен стилей и направлений, которые условно можно разделить на следующие: без предмета, с коротким оружием, с длинным оружием, подражательные упражнения (Например, «Стиль обезьяны» и др.), парные действия и гибкое оружие (см. подробно: Боевые искусства Шаолиня. Вып. 2. - М., ФиС, 1991).

Ушу объединяет в себе боевой, гимнастический, военный и др. стили. Имеются оздоровительный, психологический и философские аспекты. Ушу развивалось на протяжение десятки веков. К его развитию причастны многими тысячами прославленных ученых, военных, педагогов, врачей. Все развитие шло по пути сближения с природой, а потому, все многочисленные движения и позиции входящие в систему ушу являются естественными для человека, его анатомического строения и двигательной функции, а также потребности в развитии организма.

Следует помнить, что перед каждым занятием всегда следует четко ставить определенную цель. Например, цель - освоить комплекс 24-х форм тайцзы -цюань. При этом следует помнить, что единая цель может повторяться в следующих занятиях.

Задачи занятия:

1. Поставить правильный тип дыхания;

2. Обучиться основным движениям руками;

3. Развить необходимую гибкость тазобедренного сустава.

Исходя из поставленной цели и задач, определяется и содержание занятий. Занятие, как правило, состоит из трех частей: подготовительной, основной и заключительной.

Подготовительная часть. Подготовить организм занимающихся к восприятию специфических видов физиологических нагрузок, повышения подвижности в суставах, обучение отдельным элементам изучаемого стиля.

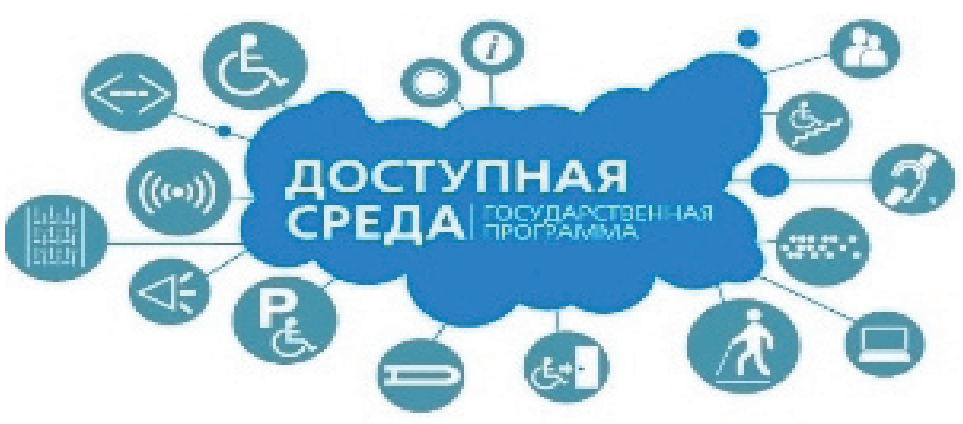

Все сказанное выше позволяет сделать следующие выводы:

1. В последние годы все увереннее набирают силы различные воспитательно-образовательные, оздоровительные системы, корни которых уходят в глубокую древность. К числу таковых можно отнести систему Кеннета Купера и Арнольда Шваццнеггера (США), Парфирия Карнеевича Иванова и Николая Ивановича Амосова (Россия), древнеиндийскую систему Йога и китайские системы У-шу, Ци-гун и Тайцзы-Цюань . Есть и другие малоизвестные, но не менее эффективные системы оздоровления и воспитания;

2. Не утратили своей значимости, а в некоторых случаях даже восстановились и обновились, системы физического воспитания и оздоровления - «Готов к труду и обороне» - «ГТО» в России, Система Президентских 
тестов в Казахстане и другие;

3. Учитывая авторитет и жизненную потребность в эффективных оздоровительных системах, на современном этапе развития общества, возникает необходимость подготовки кадров специалистов способных на научной основе пропагандировать оздоровительные системы и, в том числе, системы Древнего Востока (У-шу, Ци-гун, Йога и др.). И такими пропагандистами могли бы стать выпускники факультетов и отделений ФКиС существующие при пединститутах, академиях и университетах;

4. Данное обстоятельство заставляет руководителей факультетов, отделений и специальных кафедр готовить и читать студентам названные спецкурсы, проводить специальные семинары и «Круглые столы» несущие новые научные знания по древним и современным оздоровительным системам. Это, несомненно, повысит авторитет выпускаемых специалистов, их профессиональную квалификацию и педагогическое мастерство.

5. Знания основ оздоровительных систем Древнего Востока позволит современным специалистам создавать собственные смешанные (комбинированные) системы, а на этой основе пропагандировать передовой опыт древних, сочетая его с современными научными знаниями, существующей практики.

\section{Лекционное занятие 9-ое.}

\section{Тема: Особенности физического воспитания учащихся отнесенных к специальной} медицинской группе.

План:

1. Специальные медицинские группы для занятий физической культурой как результат целенаправленных медицинских осмотров в школах, колледжах и вузах;

2. Особенности физического воспитания учащихся и студентов после медицинского осмотра;

3. Примерное содержание физического воспитания учащихся спецмедгрупп первого и второго годов обучения.

4. Рекомендации для учителей работающих с учащимися специальных медиценских групп.

\section{Лuтература:}

1. Методические рекомендации по организации занятий с учащимися специальной медицинской группы. - Алма- Ата, 1988;

2. Дубровский В.И. Лечебная физическая культур. М., Владос, 1998, стр.542; 


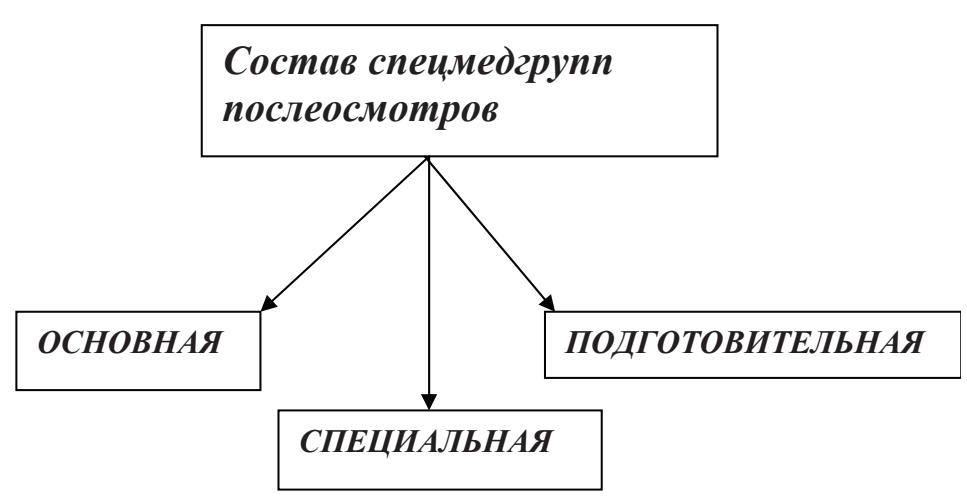

Учебные заведения всех типов (Школы, Колледжи, Вузы и др.) перед началом учебного года проводят медосмотры в результате которых все учащиеся делятся на три группы (основную, подготовительную и специальную.

Учащиеся имеющие хронические заболевания проводят занятия в подготовительной или специальных группах. Учащиеся, студенты, по внешнему виду, как правило имеют недостаточный уровень физического развитию (рост, вес,ОГК)и неумеют плавать.

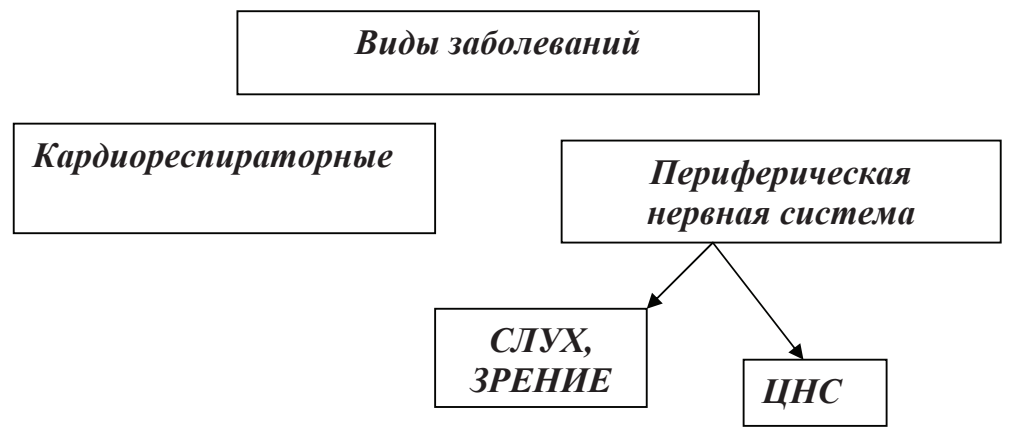

\section{Bblвodbl:}

1. Процесс физического воспитантиия в СОШ, колледжах и вузах осуществляется по результатам медицинского осмоира, в результате которого все занимающиеся делятся на группы (основную, подготовительную и медицинскую.)

2. По видам заболевантй в специальной группе осуществляется на четыре подгруппы (кардиореспираторные, периферическая НС, Слух, зрение, ЦНС.

3. Динамика изменений результатов под влиянием занятий выявляется результатоми осмотра и теми показателями, которые просматриваются в процессе исследования.

Oprmucม

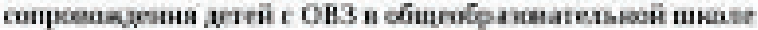

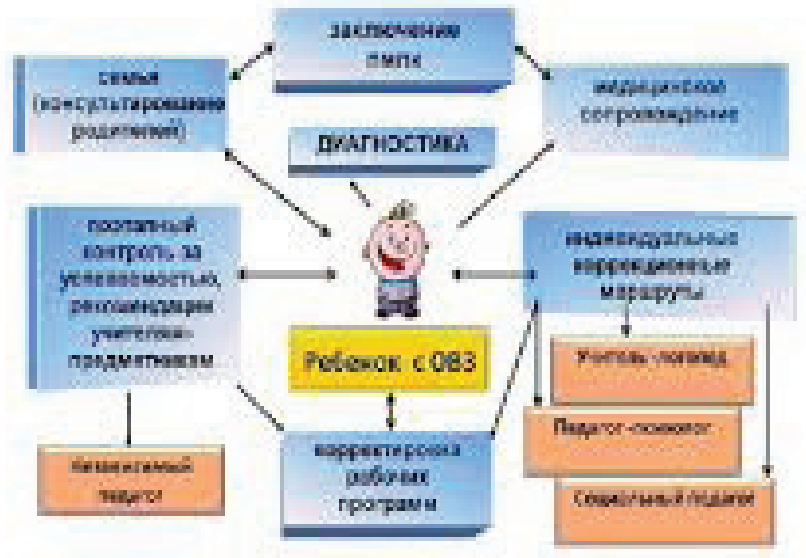




\section{Лекционное занятне 10-ое.}

\section{Тема: Формирование правильной осанки учащихся средствами ФКиС.}

Из опыта учителя СШ №24 г. Уральска,

$$
\text { А.А. Сорокиной. }
$$

План:

1. Нарушение осанки учащихся и необходимость ее восстановления, как наиболее распространной проблемы педагогического воздействия;

2. Существующий передовой педагогический опыт (СОШ №24, Учитель - Сорокина А.А.) его осмысление и выработка методических рекомендаций;

3.Предложения для учителей предметников, родителей учащихся классных руководителей вытекающие из результатов научного поиска, накопленного опыта;

4.Некоторые практические рекомендации по совершенствованию учебного процесса для вузовских факультетов (отделений) готовящих специалистов физического воспитания.

\section{Литература:}

1.Пересветов Н.Н.Аспектыфизкультурно-спортивного краеведения . Учебно-методическое пособие. тт. 1, 2 и 3. - Уральск, Полиграфсервис, 2015, 2016 и 2018;

2. Бубновский С.М. 50 незаменимых упражнений для дома и зала. - М.. Издательство «Э», 2017;

3. Дубровский В.И. Гигиена физических упражнений. - М., Владос, 2003;

4. Брэгг П.С. и др. - Санкт-Петербург, Лейло, 1995;

5. Жищенко А.Н. Коррекционные и развивающие упражнения для детей с нарушением интеллектуального развития. Методические рекомендации. - Уральск, Полиграфсервис, 2009;

6. Дубровский В.И. Лечебная физическая культура. М., Владос, 1999; Коровкин М.А. Почему дети болеют: Системная физиология ребенка/ М.А.Коровкин. - М.: ФАИР-ПРЕСС, 2003;

7. Ловейко И.Д. Формирование осанки у школьников (пособие для учителей и школьных врачей) / И.Д.Ловейко. - М.: Просвещение, 1970;

8. Милюкова И.В. Лечебная гимнастика при нарушениях осанки у детей / И.В.Милюкова, Т.А. Евдокимова. Издательство: ЭКСМО, 2005;

9. Буц Л.М. О формировании правильной осанки. - М.: 2008.

Практика современного краеведческого научного поиска дает основание утверждать, что в числе прочих методов научного поиска широко используется метод обобщений существующей передовой педагогической практики. Наши прошлые исследования располагают сведениями по обобщению педагогического опыта творчески работающих учителей нашего региона: Т.В. Харчевой, В.В. Панкратовой, А.Г. Запрометова, С.А. Абуова, С.А. Дадашевой. В.В, Пашкина и других педагогов работающих, например, в СОШ, во внешкольных учреждениях физкультурно-спортивного профиля (1.). В данном разделе учебного пособия мы делаем попытку обобщить опыт работы группы учителей во главе с А.А. Сoрокиной, накопивших опыт применения коррекционных упражнений для исправления осанки учащихся, преимущественно средствами физической культуры. Опыт рас- 
пространяется на учащихся среднего школьного возраста (5 - 9 классы) .

Анализ существующей отечественной и зарубежной литературы, личный многолетний педагогический опыт, дают основание утверждать, что в числе наиболее распространенных недугов встречающихся у учащихся современных общеобразовательных школ посещающих занятия по физическому воспитанию являются нарушения осанки (сутулость), вызванные различными искривлениями позвоночника (лордозы, сколиозы, кифозы). Другие нарушениями позвоночника встрбчаюимися в школах (В.И. Дубровский, А.А. Сорокина и др.).

Данное обстоятельство, как известно, отрицательно сказывается на работе, прежде всего, внутренних органов и систем (легких, сердца, желудка). Препятствует достижению физического совершенства молодого развивающегося организма, искажает внешний облик занимающихся (2.). Нарушение осанки препятствует нормальной жизнедеятельности всего организма, нормальному дальнейшему физическому и личностному развитию учащихся. Это обстоятельство подтверждено целым рядом исследований отечественных и зарубежных авторов В(Бубновский В.И., Дубровский В.И., Коршунов А.В., Янкелевич Е.И., Крейз Р., Нордемар Р., Хиеталла В., Брэгг П.и др.).

Накопленный и обобщенный опыт творчески работающих учителей физической культуры, спортивных тренеров, несомненно, помогает совершенствовать учебно-воспитательный процесс, и в том числе, за счет применения коррекционных упражнений исправляющих возникшие изгибы, осанку.

Особое внимание обращается на деятельность уча- щихся отнесенных к специальной медицинской группе школы, где в основном и решается данная проблема. Данная работа одновременно заставляет повышать профессиональную компетентность педагогов и авторитет предмета - «Физическая культура». Думается, что решению данной проблемы будет во многом способствовать и опыт учителей СОШ №24 г. Уральска - А.А. Сорокиной и её коллег, особенно по части дальнейшего совершенствования будущих специалистов подготавливаемых в педвузах и университетах.

Данное обстоятельство позволило нам сформулировать цель и задачи нашего многолетнего научнометодического поиска, обобщения существующего передового педагогического опыта, результатов краеведческих исследований.

Цель исследования - выявить возможность положительного воздействия на позвоночник, осанку школьников посещающих регулярно занятия физического воспитания, а на этой основе внести ряд методических рекомендаций для учителей, классных руководителей, родителей учащихся. Воздействовать, на осанку учащихся, преимущественно средствами двигательных действий (физических упражнений), конкретных видов спорта на внеклассных занятиях. Разработать обоснованные рекомендации по оздоровлению учащихся различных школьных возрастов (младшего, среднего, старшего). Обоснованно призывать в союзники родителей учащихся, классных руководителей, учителей - предметников, педагогов внешкольных учреждений, объединений учащихся по интересам сформированных по месту жительства и т.п. 
Задачи исследования:

1. Познакомиться с состоянием вопроса по литературным источникам и обобщить существующий региональный передовой педагогический опыт;

2. Провести собственные педагогические исследования на контингенте конкретной школы, учащихся преимущественно среднего школьного возраста;

3. Внести обоснованные методические рекомендации по реабилитационным мерам педагогического воздействия. А главное - вооружить в итоге студентов, будущих специалистов (учителей и спортивных тренеров) действенными методами педагогического воздействия, преимущественно реабилитационного характера.

Предмет изучения - краеведческий опыт многолетнего педагогического воздействия на учащихся имеющих нарушения осанки (лордозы, кифозы, сколиозы и др.). Опыт педагогического воздействия, преимущественно средствами физической культуры и спорта. А на этой основе, выработка обоснованных рекомендаций по педагогическому руководству учащимися, нуждающимися в двигательной реабилитации, оздоровлении.

Объект исследования - учащиеся средней возрастной группы (5-9 классы, СОШ №24. Всего - около 100 человек. Директор - К.Х. Мергенева, учитель - исследователь высшей категории: А.А. Сорокина и ее коллеги.). Опыт, который просматривается в осмыслении результатов выполнения индивидуальных заданий учащимся занимающихся в специальной медицинской группе школы.

Методы исследования: В работе широко использовались различные общенаучные и педагогические методы исследования: литературный анализ и обобщения существующего опыта; педагогические наблюдения (откры- тые и скрытые, непосредственные и опосредованные); различные виды опросов (устный, письменный и с помощью анкет); стандартизированные интервью; педагогический эксперимент (констатирующий); статистические методы обработки и анализа полученных данных. Другие научные методы.

Полученные предварительные результаты публиковались нами в специальной педагогической печати, озвучивались на педагогических советах при директоре школы, в специальных беседах с родителями учащихся, учителями-предметниками. Результаты исследований акладывались в планы воспитательно-образовательного воздействия классных руководителей и др. (1.).

В своей работе мы стремились показать влияние физических упражнений на исправление осанки молодого развивающегося человеческого организма. При этом повсеместно использовались элементы наглядности и специальные коррекционные физические упражнения, другие средства (массаж, парные бани коррегирующая гимнастика и др.), т.е. средства воздействующие в первую очередь на позвоночник и крупные скелетные мышцы занимающихся.

Анализ литературы (В.И. Дубровский и др.) показывает, что у изучаемой возрастной группы учащихся (5-9 кл) наблюдается эволюция осанки, что в свою очередь является одним из важных аспектов совершенствования опорно-двигательной системы человека. В доступной нам литературе утверждается, что осанка - свойство, присущее только человеку, результат эволюционного развития.

Выдающийся канадский физиолог Басмаджан (2.) так охарактеризовал значение этого процесса: «Среди мле- 
копитающих человек, приобретя когда-то вертикальную осанку, обладает наиболее экономичными антигравитационными механизмами. Затрата мышечной энергии при этой, казалось бы, в наименее удобной позе, предельно экономична».

С развитием цивилизации, а это общеизвестно, изменялись и требования к опорно-двигательной системе. Если древние люди часто находились в вертикальном или в горизонтальном положении (охотились, собирали плоды и коренья, воевали, отдыхали лежа и т.п.), то уже в XVII столетии более $10 \%$ населения выполняли сидячую работу, а в XXI столетии число таких работников увеличилось до 90 процентов. И эта тенденция, видимо, будет нарастать.

В процессе эволюции человек перестал приспосабливаться к окружающей среде и пытается приспосабливать среду к своей деятельности, и это обстоятельство не могло не сказаться на осанке.

Этот прогрессирующий исторический процесс имеет и оборотную сторону - у 40-80\% детей сегодня выявляются нарушения осанки, а у 3-10\% из них - фиксируются даже различные искривления позвоночника. Выявлены наличия отчетливых лордозов, кифозов и сколиозов.

С развитием цивилизации изменяются, как свидетельствует литература, содержание, организация и методы человеческого труда. Появились, так называемые, офисные работники - численность, которых составляет более 60 процентов от всего работающего населения. И эта тенденция, к сожалению, нарастает.

Необходимость длительного соблюдения сидячей рабочей позы (работая за компьютером, письменным сто-

\section{(1)}

лом с документами, общаясь с клиентами) приводит к росту числа заболеваний позвоночника, особенно взрослого населения. Число таких заболеваний, к сожалению, неуклонно будет, видимо, увеличиваться в будущем. Примерно в 80 \% случаев - это причина возникновения искривлений позвоночника, которая пока досконально не известна. Но, по нашему мнению, искривления позвоночника тесно связано с ослаблением, а в некоторых случаях недостаточной развитостью мышечной массы, особенно задней поверхности спины, мышц брюшного пресса, нижних конечностей. Такие нарушения названы в литературе - идиопатическими (что в переводе с греческого означает, как возникающие по «неизвестной причине»). Причина, как выяснилось одна - слабость, а порою и неразвитость мышечной массы.

Согласно медицинской статистике заболеваемость позвоночника растёт год от года и особенно заметна в школах и призывных пунктах военных комиссариатов. По оценкам различных специалистов до 85 процентов взрослого населения Казахстана также сталкивается с данными заболеваниями. Как правило, они (заболевания) возникают в наиболее трудоспособном возрасте в 25 - 50 лет. Однако ещё пятнадцать-двадцать лет назад болезнь позвоночника считалась заболеванием пожилых людей, а теперь всё чаще болезнь встречается в юношеском и даже детском возрасте. 


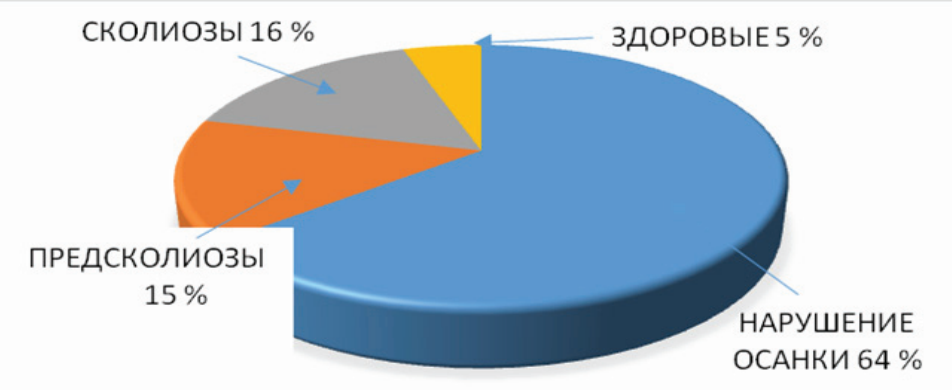

Мониторинг по заболеваемости позвоночника в Республике Казахстан. Рис.2.

Наукой доказано, что организм человека представляет собой сложную биологическую систему. Одним из важнейших звеньев которой является позвоночник, как орган, контролирующий движения. Именно позвоночник играет ключевую роль в здоровье современных школьников. Физическая активность, выносливость человека главным образом также зависит от состояния позвоночника. Выносливостью определяется мускульная сила человека. Это наивысшее состояние работоспособности человеческого тела. Когда тело здоровое и каждый мускул и орган функционируют нормально, то человек становится энергичным, выносливым, работоспособным и сильным. Физическая выносливость - это нечто большее, чем просто здоровье, чем отсутствие болезней. Это уровень приобретенной физической подготовленности, готовности человека к труду, результат тренированности

Остановимся несколько подробнее на анатомофизиологических особенностях и функциях позво- ночника в жизнедеятельности человека, учащихся. Позвоночник является основой скелета, он придаёт телу нужную форму; к позвоночнику прикрепляются пласты больших и малых мышечных групп. Связок спины и живота, которые предназначены для удержания внутренних органов, тела в вертикальном положении. Даже малейшие нарушения в позвоночнике могут отрицательно сказаться на состоянии других частей тела человека, функционировании его внутренних органов. Если же позвоночник искривлен, то это самым пагубным образом воздействует на кости скелета, мускулы и связки, которые удлиняются или укорачиваются, а внутренние органы смещаются (сжимаются), что и приводит к заболеванию всего организма.

С раннего детства человек повторяет весь процесс эволюции. Ходит, бегает, преодолевает препятствия, плавает, но всю жизнь он должен следить за своей осанкой, чтобы избежать болей в спине и пояснице. Других проблем, связанных с заболеванием позвоночника.

Сегодня доказано, что только один из каждых 150 человек среднего развития имеет достаточно гибкий позвоночник. В нашем цивилизованном обществе большинство людей ведут малоподвижный, сидячий образ жизни, переедают, а некоторые люди остаются недокормленными из-за того, что едят нездоровую, искусственную пищу. Мускулы от гиподинамии (обездвиженности) становятся дряблыми из-за отсутствия упражнений, а ткани истощаются из-за неправильного питания. От неправильного образа жизни позвоночник становится жёстким и деформированным. Хрящи и диски между позвонками разрушаются из-за отсутствия физических упражнений и плохой циркуляции крови в соседних тканях. Позво- 
ночный столб как бы «усыхает». Многие люди в 60-70 лет становятся на 3-5 сантиметров ниже, а некоторые к старости и чрезмерно сгибаются.

Известный закон биологии гласит: «Функииия - твоpum орган !». Из этого вытекают прошедшие проверку временем и практикой постулаты: «кость разрастается преимущественно по направлению тяги и перпендикулярно плоскости давления». Статическая нагрузка может оказывать негативное влияние на структуру кости, вызывая её деформацию. Согласно известному закону Гютера-Фолькмана (Hueter-Volkmann) сжимающие нагрузки приводящие к замедлению скелетного роста, а растягивающие - к его ускорению (5.). Это, например, заметно у спортсменов, специализирующихся в спортивных играх и штанге. У первых наблюдается ускоренный рост, а у штангистов, культуристов и представителей пауэрлифтинга, к сожалению, замедляется.

Связочный аппарат и нормально функционирующие мышцы без особого труда справляются с многочисленными, распространенными отклонениями в развитии скелета. Скелет человека и осанка взаимосвязаны. Если нарушается правильное развитие костей, нарушается и осанка. Скелет служит надежной опорой всего тела человека.

Еще раз замечаем, что позвоночник - это основа скелета, который выполняет в организме человека две важнейшие функции. Первая функция - опорно-двигательная. Вторая - защитная. Позвоночник предохраняет спинной мозг от механических повреждений. К нему подходят многочисленные нервные окончания, которые отвечают за работу всех внутренних органов человека. Образно говоря, каждый позвонок несет ответственность за работу определенного внутреннего органа. Замечено, что во время ускоренного роста позвоночника снижаются функции мышц и эластичности связок. Если функции позвоночника оказываются нарушенными, то затрудняется проведение нервного импульса к тканям и клеткам в разных участках тела. Со временем именно в этих участках тела могут развиваться различные заболевания. Здоровье любого позвоночника зависит от того материала, из которого он создан и от тех физических нагрузок, которым он подвергается в течение всей жизни, независимо от количества прожитых лет. В литературе отмечается: ничто не влияет на здоровье, энергию и жизнедеятельность человека так, как состояние его позвоночного столба (6.).

При правильной осанке нагрузка на позвоночник при учебе или работе распределяется равномерно, а значит не происходит перегрузки отдельных участков. Это позволяет сохранить позвоночник здоровым до преклонного возраста.

Крепкий позвоночник обладает определенной гибкостью, обеспечивающей равновесие тела. Позвоночник имеет четыре естественных изгиба (физиологические изгибы), действующих как пружина, которые смягчают резкие вертикальные нагрузки на позвоночник (прыжки и подскоки, быстрая ходьба и бег, падения и т.д.). Изгибы позволяют активно реагировать на стрессы, связанные с весом тела и его движениями, а также поглощать толчки и удары во время ходьбы, прыжков и бега. Изгибы, обращенные выпуклостью вперед, называются лордозы (шейный и поясничный), а изгибы, обращенные выпуклостью назад - кифозы (грудной и крестцовый). Кифозы - первичные изгибы, имеющиеся при рождении. Лордозы - вторичные изгибы, формирующиеся по мере 
роста позвоночника. Физиологические изгибы могут деформироваться из-за болезни или неправильной осанки, связанной со слабым мышечным корсетом и отсутствием поддерживающего тонуса мышц спины, а поэтому позвоночник начинает работать плохо, мышцы и связки становятся излишне растянутыми или сжатыми, а позвонки и межпозвоночные диски, их соединения начинают изнашиваться, в результате в спине возникает боль.

Нормальный позвоночник. Виды искривления позвоночника
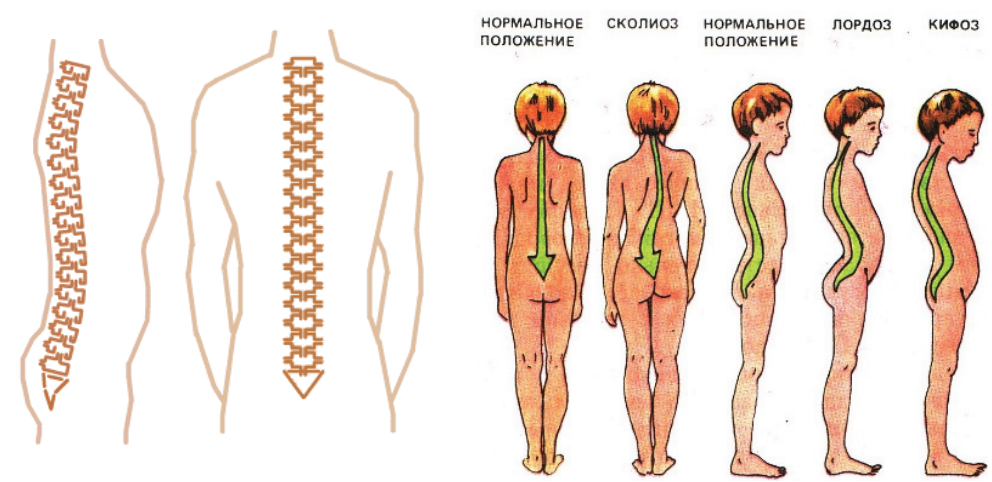

Наш многолетний педагогический опыт позволил выработать ряд рекомендаций по использованию коррекционных упражнений позволяющих устранять (упреждать) возникающие искривления в позвоночнике, нарушения в осанке.

Приступая к этой ответственной работе, мы учитывали мнение одного из классиков современной медицины (Анджело Моссо), который считает, что «Физические упражнения могут заменить множество лекарств, но ни одно из лекарств в мире не может заменить физические упражнения» (7.).
Это обстоятельство потребовало специального подбора упражнений коррегирующих осанку, совершенствующих внешний облик человека, развивающих основные двигательные качества. К таким упражнениям, по нашему мнению, относятся: а) строевые и порядковые упражнения на месте и в движении; б) упражнения, развивающие дельтовидные мышцы плеч, широчайшие мышцы спины, формирующие мышечный корсет туловища; в) упражнения, развивающие ягодичные мышцы, укрепляющие нижнюю часть туловища и конечности; г) прыжковые упражнения на месте и в движении; д) упражнения на глубокое дыхании и расслабления (8.).

Эти упражнения могут быть рекомендованы родителям учащихся, классным руководителям, учителямпредметникам для использования, особенно в дни контрольных и письменных работ, выполнения домашних заданий, напряженной учебной деятельности. (см. разделы 2 и 4.)

Коррекционные упражнения, выполняемые в проиессе уроков «Физической культуры».

(Вторая четверть, раздел «Гимнастика»).

1. Ходьба на носках, руки поднятые вверх.

2. Ходьба на наружных сводах стоп, руки в стороны.

3. Ходьба «Гусиным шагом», руки на коленях, спина прямая.

4. Ходьба с набивными мячами (палками), руки вверх или палка на плечах.

5. Ходьба на носках, в высоким подниманием коленей. 6. Ходьба подскоками, руки на поясе.

7. Ходьба с движениями рук. Сч: 1. Руки вперед. Руки в стороны. 3.Руки вверх. 4. Руки вниз. Дыхание произвольное. 
Упражнения для коррекции круглой (сутулой) спины.

(Рекомендованы для учителей, ведущих занятия в «Специальной медицинской группе»).

1. Стоя перед зеркалом. Счет: 1-2-3-4. Вращение рук назад, имитирующие движения, как в плавании на спине стилем - «Кроль». Повторить движения вперед и назад;

2. Из положения, стоя на 3-4 рейке гимнастической стенки, хват сверху на уровне пояса. Счет: 1-2 глубоко присесть, разгибая руки, выдох. 3-4 вернуться в исходное положение, вдох. Стараться спину держать прямой;

3. Из положения, стоя спиной к гимнастической стенке, ягодицы касаются рейки. Счет: 1-2. Сделать шаг правой, прогнуться, смотреть вверх на кисти рук, вдох. 3-4 вернуться в исходное положение, выдох;

4. Из положения, стоя лицом к стенке, руки хватом сверху на уровне пояса. Сч: 1. Отвести правую ногу назад, мах, прогнуться, вдох. 2. Вернуться в исходное положение, выдох. 3. Отвести левую ногу назад, мах, прогнуться, вдох. 4. Вернуться в исходное положение, выдох;

5. Стоя спиной к стенке, слегка нагнувшись. Сч: 1-2. Два круговых движения вперед, как при плавании стилем «Баттерфляй». 3-4. Два круговых движения назад. Дыхание произвольное.

6. Из виса на гимнастической стенке лицом наружу. Сч: 1. Подтянуть согнутые ноги к животу, выдох.

2. Опустить ноги, вдох. 3. Подтянуть согнутые ноги к животу, выдох. 4. Опустить, вдох;

7. Стоя лицом к гимнастической стенке, правую ногу на уровень груди. Сч: 1. Сменить положение ног. 2.то же повторить. Дыхание произвольное.
Коррекиионные упражснения выполняемые сидя на полу или гимнастической скамейке.

(Рекомендованы для учителей физической культуры).

А. Из положения, сидя на полу, колени согнуты, пятки прижаты к ягодицам - ползающие движения стоп вперед и назад за счет пальцев ног. Сч: 1- 2. Вытянуть ноги. 3 - 4. Подтянуть ноги; Б. Из положения, сидя. Сч: 1. Максимально развести ноги в стороны. 2. Скрестить ноги, правая, над левой. 3. Развести ноги. 4. Скрестить ноги, левая, над правой;

В. Из положения, лежа на животе, ноги согнуты, кисти на голеностопах. Сч: $1-2$. Медленно прогнуться, вдох. 3 - 4. Вернуться в исходное положение, выдох;

Г. Из положения, лежа на левом боку с опорой на согнутый локоть, правая рука на поясе. Сч: $1-2$. Медленно, поднять правую ногу вверх, вдох. 3 - 4.Опустить, выдох. Тоже другой ногой. Д. Из положения, упор лежа на скамейке. Сч: 1. Присесть на пятки, выдох. 2. Вернуться в исходное Положение, вдох. 3. Присесть на пятки, выдох. Вернуться в исходное положение, вдох. Е. Исходное положение тоже. Сч: 1. Повернуться на право, правую руку вверх. 2. Вернуться в исходное положение. 3. Повернуться на лево, левую руку вверх. 4. Вернуться в исходное положение.

Ж. Коррекционные упражнения, сидя за партой или за ученическим столом.

(Рекомендованы для учителей-предметников, 
классных руководителей, родителей учащихся).

3. Сидя за партой, спина прямая, голова поднята, руки на поясе. Сч: 1. Плечи послать вперед, голову опустить, выдох. 2. Вернуться в исходное положение, вдох. Тоже повторить на сч. 3 и 4;

И. Из положения, сидя, руки вытянуты вперед. Сч. $1-2$.

Потянуться правой вперед и достать край крышки парты (стола), выдох. 3 - 4 вернуться в исходное положение, вдох;

К. Из положения, сидя, руки за голову, спина прямая. Сч:

1. Наклониться локти отвести назад, вдох.

2. Вернуться в исходное положение, прогнуться, голова поднята, выдох. 3. Наклониться. 4. Прогнуться.

Л. Из положения, сидя, руки на поясе. Сч:1. Поворот туловища вправо, выдох. 2. Вернуться в исходное положение, вдох. 3. Поворот влево, выдох. 4.Исходное положение, вдох;

М. И.П. тоже. Сч: 1. За счет сокращения ягодичных мышц, приподняться, плечи отвести назад, вдох.2. Вернуться в исходное положение, выдох. 3. Приподняться, вдох.

4. Опуститься, выдох;

1. Из положения, сидя, руки на ушных раковинах. Сч:

$1-2-3-4$. Массирующие движения, вперед.

$1-2-3-4$. Массирующие движения, назад. Дыхание произвольное;

2. Из положения, сидя, руки к плечам. Сч: 1 - 2.Руки вверх, потянуться, вдох. 3 - 4. Руки вниз, выдох. Дыхание произвольное;
Коррекичионные упражнения боковых (сколиозных) искривлений позвоночника (начальная стадия).

(Рекомендаџии для учителей работающих в спещчиальHblx гpynnax).

1. «Кошечка». Из положения, стоя на четвереньках.

Опускание и поднимание головы с прогибанием в поясничном отделе с последующем разгибанием в грудном и поясничном отделах позвоночника .

2. «Колечко». Из положения, стоя на коленях, Руки на поясе. Прогибаясь назад до касания пола головой. Выполняется со страховкой.

3. «Ванька-встанька». Из положения, сидя с максимально согнутыми коленями, прижатыми к груди. Сч: 1-2. Перекат назад. 3-4 Возвращение в исходное положение. Упражнение выполнять «Змея». Из положения, лежа на животе. Руки на уровне плеч. Ладони на полу. Сч: 1-2. Медленно разгибая руки и поднимая голову, максимально прогнуться в грудном и поясничном отделах позвоночника. Голову предельно откинуть назад, вдох. 3-4. Вернуться в исходное положение, выдох;

4. «Лодочка». Из положения, лежа на животе, руки за спиной. Сч: $1-2-3-4$.Покачивание вперед и назад, голова откинута;

5. «Пловец». Из положения, лежа на груди. Движение руками как в плавании стилем - «Брас». Упражения выполнять с постепенным увеличением амплитуды движений. Руками пола не касаться;

6. «Спринтер». Бег на месте с переменной скоростью;

7. Упражнения, успокаивающие дыхание. Сч. 1 - 2 . Руки 
Через стороны вверх, вдох. 3 - 4. Руки опустить, выдох.

Коррекиионные упражнения и игры во время

больших перемен и внеклассных занятий в школе.

(Рекомендуется для учителей, дежурящих по школе).

1. Подвижная игра «Мяч на веревочке - «Удочка».

Учащиеся располагаются по кругу, взявшись за руки.

Учитель или ведущий. Вращает мяч по кругу, а учащиеся должны подпрыгнуть, чтобы не задеть мяч. Те кого мяч задел - выходят из игры или становятся водящими;

2. Подвижная игра «Вороны и воробьи». Играющие делятся на две группы, стоя в шеренгах спиной друг к другу. Расстояние: 1 - 1,5 метра. Первая шеренга - «Воробьи», вторая - «Вороны». Ведущий (или дежурный Учитель) подает медленно команду -« Во - ро - бьи!»

Или «Во - ро - ны!». Те, кого назвал «Ведущий», должны убегать, другие их ловить.

3. Подвижная игра «Догони последнего» или «Коршун и цыплята». Учащиеся стоят в колонне, руки на поясе впереди стоящего. Направляющий - «наседка». Все остальные - цыплята. Один из играющих, должен забежать в конец колонны и поймать «цыпленка»;

4. Эстафеты различной тематики: «Арифметические», «Литературные», «Краеведческие», «Исторические», «Географические», «Физкультурно-спортивные» и др.

5. Размеренный бег «трусцой» по кругу или подскоки через скакалку.
Опираясь на ранее разработанные коррекционные методики, мы провели формирующий педагогический эксперимент протяженностью - один учебный год. Начало эксперимента - сентябрь. Конец - май месяц. В эксперименте участвовали учащиеся среднего школьного возраста (5 - 9 кл.). Всего 15 человек. Мальчиков - 7, девочек - 8 человек. Занятия проводились усилиями учителей физической культуры школы при участии работников медицинского кабинета и некоторых родителей учащихся. Продолжительность коррекционных занятий, по согласованию с дирекцией школы, составляла 40 минут. Два раза в неделю (Понедельник, пятница) с $13^{00}$ до $13^{40}$ час.

На фоне широкого использования общеразвивающих упражнений, подвижных игр ставилась задача значительно укрепить мышцы задней поверхности спины, обеспечить правильную осанку, сформировать мышечный корсет нижней части торса, развить мышцы живота занимающихся. Результаты эксперимента представлены в таблице № 1 . 
Таблица 1.

Результаты коррекционной деятельности с учащимися, на примере учащихся специальной медицинской

$$
\text { группы. }
$$

Оиенка по 10-бальной системе

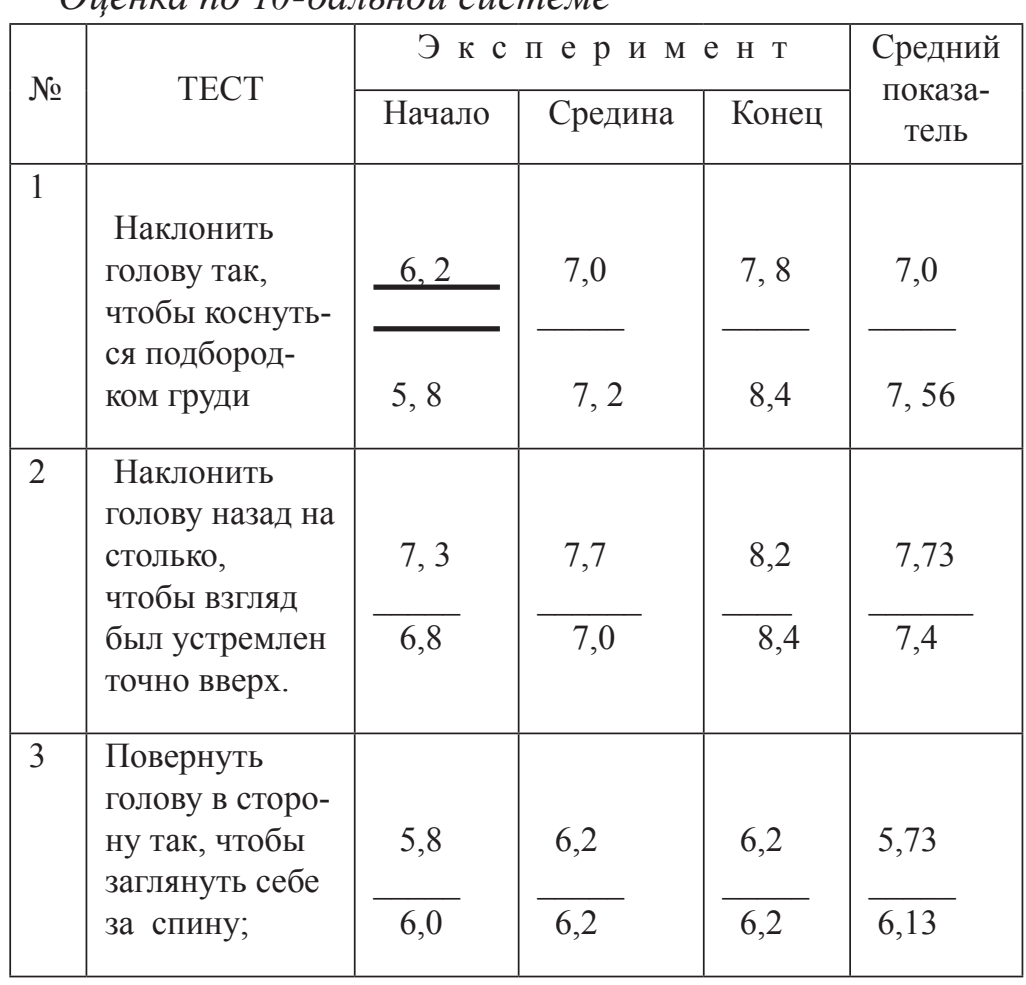

\section{Пояснения: В числителе - данные мальчиков;} В знаменателе - данные девочек.

Результаты, представленные в таблице № 1, дают основания считать, что под влиянием специально подобранных (коррекционных) физических упражнений произошли заметные положительные изменения. Однако следует подчеркнуть, что эти изменения происходили медленно и первоначально едва заметно. Процесс активизировался под влиянием больших усилий со стороны педагогов, самих учащихся и их родителей. К этому заметим, что усилия предпринятые учителями физической культуры были поддержаны педагогами других учебных дисциплин, особенно классными руководителями и родителями учащихся. Этому способствовали, видимо, и серия родительских собраний, где была четко сформулирована существующая проблема, намечены средства и методы достижения желаемого результата. Собраны фактические данные, произведен статистический анализ.

Вот только некоторый перечень тем рассматриваемых на уровне классных руководителей, а через них и на собраниях родителей учащихся:

a) Технический прогресс и влияние обездвиженности (гиподинамии) на внешний облик, осанку учащихся;

б) Наиболее распространенные искривления позвоночника у учащихся средней возрастной группы (5-9 кл.) и необходимость целенаправленного использования коррекционных упражнений в школе и дома;

в) Коррекционные упражнения в школе и дома - действенное средство формирования внешнего вида, правильной осанки учащихся;

г) Упражнения, укрепляющие заднюю поверхность туловища учащихся имеющих начальную стадию сутулости. (Методические рекомендации для учителейпредметников);

д) Упражнения в положении сидя за партой или ученическим столом. (Методические, рекомендации для родителей учащихся); 
е) Подвижные игры, развлечения и рекреационные упражнения в период больших перемен, вне учебной рекреационной деятельности учащихся.

Все эти рекомендации, побудили нас к дальнейшему литературному анализу и обобщениям существующего передового педагогического опыта.

Литературные данные и обобщенный передовой опыт позволяют утверждать, что нарушение в позвоночнике это заболевания, которые могут привести к затруднениям в работе сердца, уменьшению жизненного емкости легких, ухудшению деятельности органов кровообращения, пищеварения, выделения. Все это приводит к быстрой утомляемости, головокружениям и даже частым головным болям. У школьников снижается общая работоспособность, учиться и работать становится труднее.

«Осанка» и ее роль для жизнедеятельности человека, учашихся.

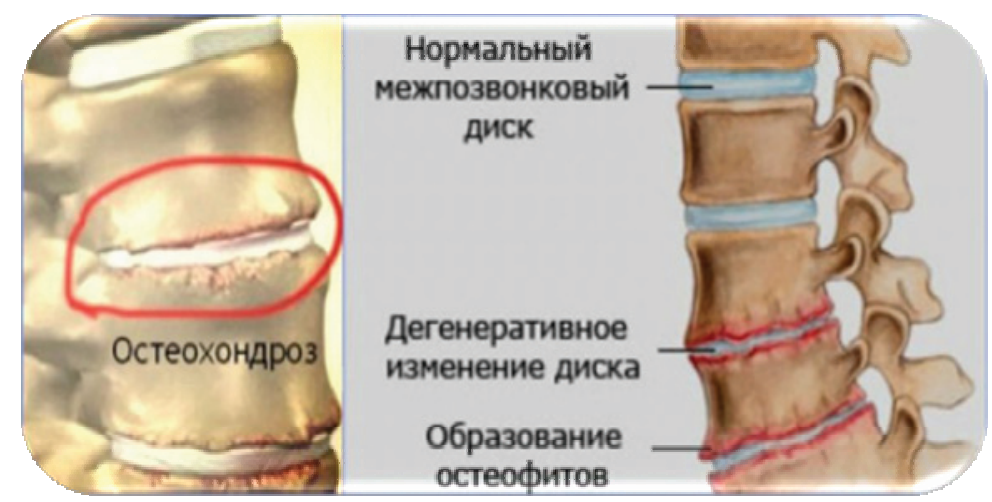

Физическое воспитание рассматривает осанку как основной показатель физического развития и физического здоровья человека. Осанка - фактор повышения эффек- тивности движений, средство профилактики спортивного травматизма и заболеваний опорно-двигательного аппарата.

Медицина рассматривает осанку как показатель физического здоровья.

Осанка - это ориентация в пространстве вертикально расположенного тела человека, которая выполняет контроль за простыми и сложными движениями. Осанка, определяет состояние мышечного и скелетного равновесия, которое предохраняет опорные конструкции тела от травм или прогрессирующей деформации, как в покое, так и во время движений.

Каждый взрослый имеет определенную, свойственную только ему осанку. От рождения до глубокой старости человек проходит определенные этапы развития. Изменяются формы и пропорции тела, изменяется нервная система и, вместе с ней, формируются, закрепляются и угасают комплексы безусловных и условных рефлексов. Все это, так или иначе, отражается на осанке.

Изменение осанки в процессе индивидуального развития человека - важный аспект жизнедеятельности человека. У новорожденного ребенка, например, количество костей в позвоночнике больше, чем у взрослого человека. Этому, видимо, имеется свое логическое объяснение. По мере роста малыша количество костей сокращается. Это происходит за счет срастания отдельных частей тела с тазом. В итоге создается крепкая и надежная костная система.

Процесс формирования осанки начинается с возраста от 6 до 8 лет и продолжается до возраста от 17 лет до 21 года. Это происходит по мере созревания нервномышечной системы и формирования устойчивого двигательного стереотипа. 
Итак, осанка - это привычная, непроизвольная поза человека проявляющаяся как в состоянии покоя так и во время движения. Ее основой является позвоночник. Она формируется в процессе роста и развития человека и изменяется в зависимости от условий быта, учебы, труда, занятий физическими упражнениями. Поэтому очень важно со дня рождения ребенка заботиться о формировании правильной осанки, о его всестороннем физическом развитии. Осанка считается правильной, если голова слегка приподнята, грудная клетка развёрнута, плечи находятся на одном уровне; голова и позвоночник, если смотреть сзади, составляют прямую вертикальную линию, а если смотреть сбоку, позвоночник имеет небольшие углубления в шейном и поясничном отделах и небольшую выпуклость в грудном отделе туловища. Правильная осанка зависит от нормального развития позвоночника.

Правильная осанка характеризуется симметричным развитием правой и левой частей тела, при этом шейные и поясничный отделы позвоночника слегка прогнуты вперед, грудной - назад, естественные изгибы позвоночника выражены умеренно, лопатки расположены симметрично, плечи на одном уровне и слегка развернуты, живот подтянут. Мускулатура рельефна, все суставы подвижны. Ноги прямые, смыкание бедер, коленей, голеней и пяток происходит без особого напряжения мышц, с небольшим просветом ниже коленей и над внутренними лодыжками. Внутренние части стоп не касаются пола. Формы стопы имеет большое значение для смягчения удара при прыжках, ходьбе, беге, толчках. Осанка зависит от формы и гибкости позвоночника, угла наклона таза, положения головы, плечевого пояса, от состояния мышц, связок, нервной системы, зрения и т.п. От умения правильно держать свое тело зависит не только внешний вид человека, но и их здоровье.

Основная задача осанки - предохранение опорнодвигательной системы от перегрузки и травмы за счет рационального выравнивания сегментов тела и баланса мышц.

Успех в формировании правильной осанки достигается прежде всего путем укрепления мышечной системы, её разносторонней физической тренировкой. При нормальной осанке создаются благоприятные условия для работы внутренних органов, особенно, сердечнососудистой, дыхательной и мочевыделительной систем. Хорошая осанка содействует поддержанию чувства бодрости и уверенности. Формированию правильной осанки способствуют закаливающие процедуры, физические упражнения, занятия плаванием, ритмической и художественной гимнастикой. Большое значение имеет сбалансированное питание и полноценный сон, дающий отдых центральной нервной системе, мышцам и уменышающий нагрузку на позвоночник и суставы.

Таким образом, между осанкой и здоровьем существует прямая связь, правильная осанка - это не только залог красоты, но и основное условие крепкого здоровья.

Основная причина нарушении осанки - это гиподинамия, или недостаточная двигательная активность, которая ведет к снижению уровня физического развития людей, ухудшению состояния внутренних органов и постепенному уменьшению сопротивляемости организма. У таких людей, как правило, слабый мышечный корсет, то есть плохо развитые мышцы спины и живота. А это, в свою очередь, ведет к нарушениям осанки и прогрес- 
сированию сколиозов. Поэтому нарушение осанки не должно расцениваться как безобидная деформация, не требующая коррекции.

Нарушения осанки возникают также в результате отклонений в состоянии здоровья, вызванных различными инфекционными заболеваниями.

Согласно новой концепции, внутренней причиной возникновения нарушения осанки и сколиозов у взрослых и детей служит недостаточная устойчивость у них общего центра тяжести тела. Осанке же при этом отводится роль системы, обеспечивающей равновесие организма в пространстве.

Снижение рессорной функции позвоночника приводит к постоянным микротравмам головного и спинного мозга во время ходьбы, бега и других движений, что отрицательно сказывается на высшей нервной деятельности, сопровождается снижением работоспособности. Кроме того, при наличии дефектов осанки внутренние органы могут отклоняться от нормального положения и зажиматься другими органами и тканями. Спинной мозг, находящийся в позвоночнике, участвует в большинстве рефлексов. При нарушении положения позвоночника происходит зажатие спинномозговых нервов, нарушается циркуляция спинномозговой жидкости, что оказывает негативное воздействие на весь организм. В большинстве случаев нарушения осанки являются приобретенными.

Виды и признаки нарушения осанки

Наблюдается три степени нарушения осанки. Первая степень - изменен лишь тонус мышц. Все дефекты осанки исчезают, когда человек выпрямляется. Нарушение легко исправляется при систематических занятиях кор- ректирующей гимнастикой.

Вторая степень - изменения в связочном аппарате позвоночника. Изменения могут быть исправлены лишь при длительных занятиях корректирующей гимнастикой под руководством медицинских работников.

Третья степень - характеризуется стойкими изменениями в межпозвоночных хрящах и костях позвоночника. Изменения не исправляются корректирующей лечения. Чтобы не допустить дефектов в осанке, необходимо с раннего возраста осуществлять профилактические мероприятия, способствующие правильному развитию опорно-двигательного аппарата ребенка. Виды нарушения осанки разделяют на нарушения осанки во фронтальной (вид сзади) и в сагиттальной плоскости (вид сбоку).

a) Лордическая осанка. Лордоз шейного отдела - это изгиб позвоночника вперед в области шеи. Небольшой изгиб присутствует у всех людей. Нарушением осанки считается его отсутствие, то есть шея выпрямлена полностью без изгиба, а так же чрезмерный изгиб, когда голова заметно выступает вперед относительно тела.

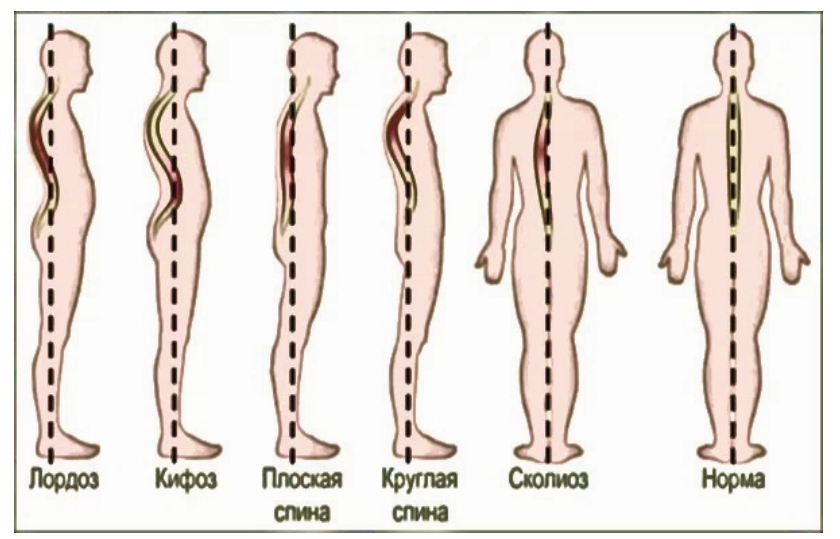


Наиболее часто встречается второй вариант, когда шейный лордоз увеличен. Это следствие выдвинутой вперед головы, и чтобы сохранить равновесие и равномерно нагружались шейные позвонки, шейный отдел позвоночника излишне изгибается. Многие даже и не догадываются что у них шейный лордоз, лишь у небольшой части это вызывает боли в шее. Как выглядит шейный лордоз? При взгляде сбоку голова как бы запрокинута назад, и шея визуально выглядит укороченной. Из-за этого мышцы шеи постоянно находятся в напряжении. б) Кифотическая осанка (сутулость, круглая спина) - явно выраженное увеличение грудного кифоза, часто сочетающееся с уменьшением поясничного лордоза вплоть до его полного отсутствия. Голова наклонена вперед, которая легко определяется выступающим остистым отростком седьмого шейного позвонка, что отмечается привычным полусогнутым положением коленных суставов. При длительно существующей кифотической осанки происходит деформация фиксируется (особенно часто у мальчиков) и коррекция ее становится невозможной при активном напряжении мышц. Причиной развития круглой спины может быть связано с систематическим пребыванием в положении сидя или лежа «калачиком», когда мышцы задней поверхности бедер и ягодичные мышцы находятся в состоянии растяжения. Поскольку положение таза в значительной мере зависит от равномерной тяги этих мышц, то при ее нарушении увеличиваются наклон таза и поясничная кривизна позвоночника, что и наблюдается в положении стоя (9.).

в) Выпрямленная осанка. Плоская спина - длинное туловище и шея, плечи опущены, грудная клетка уплощена, живот может быть втянут или выпячен вперед из-за слабости мышц, физиологические изгибы позвоночника почти отсутствуют, нижние углы лопаток резко выступают сзади (крыловидные лопатки), сила и тонус мышц обычно снижены. Создаются благоприятные условия для прогрессирования бокового искривления позвоночника, обусловленного сколиотической болезнью.

г) Сутулая. Сутулость обычно возникает из-за непропорционального развития грудных мышц и верхних мышц спины. Если грудные мышцы более развиты чем верх спины, а это очень частое явление даже для тех, кто не посещает тренажерный зал, то они будут оттягивать плечи вперед, так как не встречают сопротивления со стороны мышц прижимающих лопатки к телу.

д) Сколиоз. Если сколиоз - это боковое искривление позвоночника, то становится понятным, откуда пошло название сколиоза грудного отдела - оно походит из места положения, в данном случае на уровне груди. Чаще всего сколиоз грудного отдела встречается с одной дугой. То есть искривление при взгляде спереди напоминает букву «С». Она может быть обращена вершиной в правую или левую сторону.

Осанка изменяется по нескольким причинам:

- слабое развитие мышц спины и брюшного пресса, отсутствие мышечного корсета привыкание к неправильному положению;

- неправильное расположение тела формируется в ходе различной, часто повторяющейся, двигательной деятельности;

- различные врождённые заболевания, как внутренних органов, так и опорно-двигательного аппарата, при наличии которых осанка оказывается далека от идеальной 
- сидения за столом, сгорбившись;

- передвижения ссутулившись, когда одна рука находится в кармане (налицо искусственный перекос плечевого пояса и нарушенная осанка) и т.д.

Сидячий образ жизни, малоподвижность, отсутствие необходимой гимнастики у современного человека приводят к серьезным нарушениям осанки, что впоследствии может вылиться в самые разные болезни позвоночника, нервной системы и внутренних органов.

Многие люди считают эту патологию не столь существенной в ряду других более серьезных и опасных заболеваний. Ведь именно с нарушений в позвоночнике и начинаются серьезные беды и уже потом те самые опасные заболевания, которые заставляют нас задуматься. Дети и взрослые с нарушением осанки должны большую часть времени проводить в движении. Во время движения происходит укрепления мышц и скелета.

У человека с неправильной осанкой голова излишне запрокинута назад, или опущена вперед, плечи сведены вперед, спина сутулая, грудная клетка запавшая, живот выпячен. Правая и левая стороны тела несимметричны: на разных уровнях плечи и нижние углы лопаток; неодинаковы треугольники талии. При появлении дефектов осанки изменяется не только внешний вид человека (неуклюжая походка, асимметричное положение плечевого и тазового пояса), но и возникают серьезные отклонения от нормы. Так, изменение грудной клетки (куриная и плоская грудь), поясничного изгиба, выпячивание живота, укорочение грудных мышц и другие дефекты осанки затрудняют работу внутренних органов, отражаются на психическом и физическом развитии взрослых и детей.

Из всего вышесказанного можно сделать вывод, что осанкой называют, как умение без особого напряжения удерживать свое тело, сохраняя правильную позу в положении сидя, лежа и во время ходьбы, так и саму эту правильную позу.

Несколько тестов, которые подтвердили положительную динамику коррекции.

- Наклонить голову так, чтобы коснуться подбородком груди;

- Наклонить голову назад на столько, чтобы взгляд был устремлен точно вверх.

- Повернуть голову в сторону так, чтобы заглянуть себе за собственную спину;

- Наклонить голову в сторону так, чтобы верхний край одного уха находился на уровне с нижнем краем другого.

Проверить осанку можно доступным для каждого способом. Например:

Подойти к стене и встать к ней спиной. Если тело соприкоснулось с поверхностью стены в четырех точках: затылок, лопатки, ягодицы и пятки, значит осанка правильная. Если же наблюдаются нарушения, то следует решить, каким коррегирующим комплексов следует воспользоваться.

Выполнять упражнения коррегирующих комплексов следует как можно чаще в течение всего дня. Как только вы сможете удерживать такое положение тела у стены в течение минуты без утомления, тогда, сохраняя ту же осанку, идите вперед.

Если у вас сильный, вытянутый позвоночник и вы ходите прямо, то все удары при ходьбе поглощаются хрящевыми пластинками и дисками, которые выполняют роль пружины и защищают спинной и головной мозг от повреждения. 
Если при ходьбе появляются боли, то вы должны контролировать два ключевых места - ноги и позвоночник.

Необходимо так же систематически следить за осанкой и во время ходьбы. Следует помнить, что во время ходьбы плечи нужно держать на одном уровне и слегка отводили их назад, нижние углы лопаток чуть - чуть сводить, мышцы живота подтягивать, нельзя сгибать туловище вперед и раскачиваться в стороны. Сама природа сделала ходьбу идеальным упражнением, которое омолаживает весь организм.

Сидеть надо так же правильно, как и стоять. Основание позвоночника должно находиться на задней части жесткого и прямого сиденья. Спина должна плотно прилегать к спинке стула, форма которого должна соответствовать кривой позвоночника. Живот должен быть плоским и твердым, не расслабленным, плечи прямые, голова высоко поднята.

Не следует класть ногу на ногу: увеличивается нагрузка на нижний отдел позвоночника и на какое-то время нарушается кровообращение в ногах. Это вызывает боль в нижней части позвоночника и может привести к заболеваниям половых органов. Не следует плюхаться на стул: хрящевые пластинки и диски в результате резких ударов постепенно стираются. Садясь на стул, опускайте тело легко и мягко, голова должна быть направлена вперед и вверх, шея расслаблена, позвоночник вытянут. Вес тела приходится только на ступни, лодыжки и бедра - эти мощные упругие рычаги должны мягко опускать тело на стул.

Вставать со стула тоже надо правильно. Поднимаясь, выталкивайте тело вверх, позвоночник же будет держать голову и торс прямо. Не помогайте себе руками, когда встаете и садитесь.

Во время ночного сна или просто небольшого отдыха позвоночник должен быть ровным в постели. Жесткий, плоский, но достаточно эластичный матрац даёт возможность костям плеч и таза сформировать свой собственный естественный прогиб. Небольшая и достаточно мягкая подушка для головы и шеи позволяет удерживать верхнюю часть позвоночника в совершенно прямом положении. Никогда не допускайте, чтобы какая-нибудь часть тела давила на другую, так как это препятствует циркуляции крови.

Данная информация позволила нам подготовить содержательные беседы для различной категории слушателей: учителей физической культуры - коллегам по специальности, учителям - предметников не физкультурных специальностей, классных руководителей и воспитателей других рангов и, конечно, родителям учащихся, которые, по нашему мнению, могут значительно помочь в решении проблемы, в целом.

Все сказанное позволяет заключить и сделать следуюшие выводы:

1. Правильная осанка - это наиболее приемлемое положение тела, которая используется в вертикальном положении (стоя). Осанка формируется в процессе жизнедеятельности с момента рождения и роста человека. Однако замечено, что нарушение осанки у учащихся, к сожалению, нарастает. Это может происходить и под влиянием внешних факторов: недостаточно развитых мышц спины и других частей тела. Крайне отрицательно нарушение осанки влияет на жизнедеятельность внутренних органов, общее состояние здоровья, самочувствие учащихся. 
Педагогам физического воспитания, родителям учащихся необходимо помнить, что легче предотвратить нарушения осанки, чем её в дальнейшем исправить. Поэтому необходимо всегда следить за осанкой, постоянно тренировать мышцы туловища, особенно мышцы спины и живота, формировать мышечный корсет. Энергия человеческого организма огромна, а тело, как доказано, - самоисцеляющая система и его следует активно поддерживать. Только сам организм может восстановиться при условии, что будет обеспечена поддержка ему правильным питанием, рациональной физической активностью и целенаправленными, коррекционными и общеукрепляющие физические упражнения, восстановительным массажом.

2. Необходимо помнить, что тело учащихся будет сильным, если его всегда поддерживать в активном состоянии. Для того чтобы быть здоровым позвоночник в особенности нуждается в ежедневной физической нагрузке, специальных коррекционных упражнений. Упражнения для позвоночника должны стать таким же необходимым атрибутом жизнедеятельности, как питание, умывание, использование других средств личной и общественной гигиены.

3. Наряду с пищей, водой и воздухом наше тело нуждается в движениях для поддержания нормальной жизнедеятельности. Так же, как и пища, вода и воздух наши двигательные привычки могут иметь различное качество. В повседневной жизни мы каждую секунду обогащаем свой двигательный опыт, самосовершенствуемся или деградируем.

4. Мы можем позволить телу - в силу своего пренебрежения или безразличия - осунуться, согнуться, око- стенеть или раздаться вширь. И, наоборот, мы сможем стоять и двигаться легко, свободно, изящно и с достоинством, долго сохранять здоровье и работоспособность, быть успешными в жизни, не болеть.

5. Только двигательная активность и желание заниматься физическими упражнениями позволяет человеку сохранить здоровье. Улучшать не только физическое самочувствие, но и снимать усталость и нервное напряжение. Высказывание Аристотеля: «Движение - это есть жизнь» является основным мотивом для занятий физическими упражнениями, для сохранения собственного здоровья и это, как и прежде, остается актуальным для учителей физического воспитания, особенно, проводящих занятия в специальных медицинских группах.

6. Проведенные исследования на контингенте среднего звена учащихся обеобразовательных школ дает основание утверждать, что профилактическая работа над вопросами осанки человека дает положительные эффекты. Правильная осанка не только сохранется но и совершенствуется при правильной организации занятий.

7. В условиях школы результаты по сохранению правильной осанки достигается работой спецмедгрупп и воспитательно-образовательной работы классных руководителей, родителей учащихся. 


\section{КОМПЛЕКС УПРАЖНЕНИЙ ПРИ ДОЛГОЙ РАБОТЕ СИДЯ}

1. Боковые растяжения мышц шеи и затылка. В положении сидя поместить ладонь на ухо через голову, а второйть: рукой крепко держитесь за край сидения. Осторожно потяните голову в сторону.

2. Растяжение и мобилизация позвоночника. Откиньтесь на спинку стула (спинка должна заканчиваться на высоте лопаток).

3. Скрестите ладони на затылке и медленно потянитесь корпусом назад за спинку стула.

4. Растяжение нижней половины спины. Сядьте на стул, как можно глубже. Слегка расставьте ноги и прижмите ступни к полу. Соедините руки над головой и уроните вперёд вниз верхнюю часть корпуса.

5. Растяжение передних мышц бедра. Встаньте рялом со стулом., держась за спинку. Согните ногу и возьмитесь за щиколотку. Медленно тяните ногу вверх. Тоже самое проделайте с другой ногой.

6. Растяжение задних мышц бедра. Поставьте пятку на стул, слегка согнув колено. Давите на колено, пока не почувствуете, как тянуться задние мышцы бедра. Через 10 секунд смените ногу.

7. Растяжение передних мышц таза.

Поставьте ступню на стул в широком шаге. Обопритесь руками в колено и медленно двигайте таз вперёд сделайте выдержку 20 секунд и смените ногу.

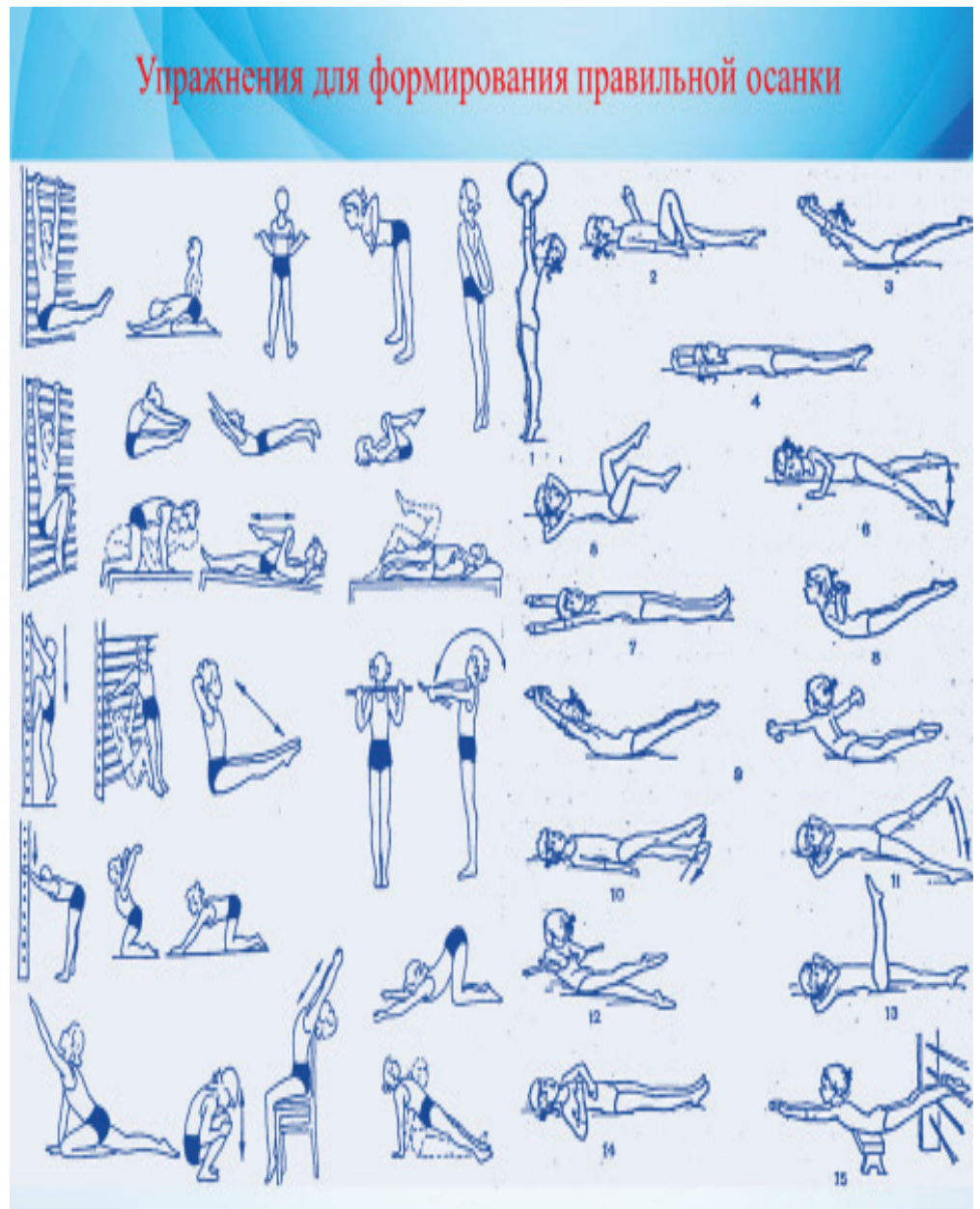




\section{Лекционное занятие 11-ая}

\section{Тема: Особенности учебно-воспитательной работы} со слабослышащими. позднооглохшими

детьми дошкольного возраста.

План:

1. Причины нарушения слуха у позднооглохших детей и подросков оглохших отличия в характеристике личности

2. Слаболышащие, позднооглохшие подростки и методика работы с ними;

3. Подвижные игры и подводящие упражнения в работе с позднеоглохшими учащимися.

\section{Литература:}

1. Аринин Ю.Л. и др. Твой спортивный уголок. М., ФиС, 1989;

2. Жищенко А.Н. Коррекция и развивающие упражнения для детей с нарушением интеллектуального развития. - Уральск, 2009, стр.56;

3. Бирюков А.А. Классический массаж. - М., Знания, 1989 ;

4. Щуркова Н.Е. Классное руковдство: игровые методики. - М., Педагогич. обществ России, 2002.

5. Общие основы лечебно-физической культуры. В кн: Лечебная физическая культура. - М., Владос, 1998, стр.13.

Слух, как известно, имеет огромное значение для роста и развития человека. К сожалению количество глухих детй повсеместно нарастает. Количество детей ли- шенных слуха ежегодно прирастает по 4-5 человек на 100-тысяч РОЖДЕННЫХ. Это приводит к тому, что познание окрестностности, окружающей действительности крайне дезатрудинено. Ребенок не сможет самостоятельно научиться говорить, так как не воспринимает речь, не слышит звуковых образцов.

Нарушения слуха могут быть врожденными и приобретенными. Врожденные нарушения слуха встречаются значительно реже (в 25\% случаев), чем приобретенные.

Среди причин, вызывающих приобретенные недостатки слуха, основное место занимают инфекционные заболевания, перенесенные в грудном и раннем детском возрасте.

Так мировая практика показывает и статистика говорит о том, что на 100000 новорожденных рождается 3-5 детей с врожденными нарушениями слуха, а к 10 годам подрастания просматривается достаточно большое количество учащихся, которые нуждаются в специальном использовании физических упражнений в интересах образования и воспитания детей и подростков с нарушениями слуха, осанки и т.д.

Глухота в раннем детстве бывает абсолютной в исключительных случаях. Обычно остатки слуха позволяют воспринимать отдельные очень громкие, резкие и низкие звуки, однако разборчивое восприятие речи обычной громкости невозможно.

Отдельную группу, в отношении формирования речи и ее восприятия составляют позднооглохнувшие. У таких детей может быть разная степень нарушения слуха и также разный уровень сохранности речи. При этом у рано оглохнувших детей резко ограничена возможность овладения словесной речью, что приводит в последствии к глухоне- 
моте, так как ребенок не может разборчиво воспринимать чужую и собственную речь, подражать окружающим.

Глубокое и стойкое нарушение слуха оказывает отрицательное влияние на психическое, физическое и личностное развитие ребенка. Главной и наиболее трудной задачей воспитания и обучения глухих детей является формирование у них словесной речи и речевого мышления.

В отличие от глухих детей, слабослышащие обладают остаточным слухом, что можно достаточно эффективно использовать в процессе занятия физической культурой, для общения с окружающими и познания мира. Здесь также возможна корректировка, набор и овладевание речевым запасом. При применении адаптивных методик физического развития и работе с такими детьми надо также учитывать и степень снижения слуха (легкая, умеренная, значительная или тяжелая) и длительность этого снижения.

Речь слабослышащих имеет свои особенности. Ребенок какие то звуки не улавливает совсем, другие не воспринимает как здоровые люди на 100\%. Так он искаженно слышит слова, и искаженно их воспринимает, что в дальнейшем затрудняет и произношение и написание. Дети легко путают предметы и действия и близкие по звучанию слова, что также влияет на их неспособность заниматься в обычных школах. При этом своеобразие речи слабослышащих детей следует рассматривать не столько как недостаточность, сколько как процесс замедленного поступательного развития речи, подчиненного особым закономерностям.

Зачастую окружающие речевые затруднения слабослышащих детей воспринимают как рассеянность, невнимание и даже как интеллектуальная недостаточность. Ребенка зачастую ругают, а иногда и наказывают за упрямство, неграмотность, лень, не понимая истинных причин такого поведения. В результате такого неправильного отношения к ребенку вызывает у него отрицательное поведение (нерешительность, плаксивость, замкнутость, неуверенность, раздражительность, негативизм). Поэтому обязательным условием успешного развития слабослышащих детей является правильное организованное воспитание, где большую роль уделяют физическому развитию.

В работе с такими детьми важно выработать и использовать имеющийся уровень речи и слуха для общения, на основе которого строится вся коррекционная работа. Это может быть язык жестов и мимики, который находит педагог совместно с родителями. Необходимо обогащать сенсорное восприятие малыша, включая в совместную деятельность любой способ опосредования, стараться находиться в зоне его видимости, попутно громко и четко произнося все действия.

Также важно включать такого ребенка во взаимодействие со сверстниками. Смысл коррекционной работы для ребенка с нарушением слуха заключается в том, чтобы создать такие условия для его развития и обучения, которые позволят расширить и качественно изменить доходящие до него внешние воздействия, изменить количественный и качественный состав речи, то есть заменить акустические воздействия на равные им по значению. Здесь также кроме физических упражнений и адаптивной гимнастики и массажей, необходимо обучать ребенка чтению, научить читать с губ, жестов, выполнять действия по подражанию, использовать символы - опоры.

Так как работа по развитию слухового восприятию и обучению произношения образует целостную взаимосвязанную систему, специальные формы работы на всех этапах 
обучения оказываются едиными. Это также индивидуальные занятия по развитию слухового восприятия и обучению произношения слов. Очень хорошо использовать методику и систему игр. Здесь также надо выделить важность занятий на музыкальных инструментах, где осуществляется систематическая работа по развитию и корректировки слухового восприятия звуков и музыки. Данная работа имеет большое значение как для эмоционального, так и эстетического развития слабослышащих детей.

Разнообразие методических приемов при обучении различию и опознаванию речевого материала имеет важное значение для детей дошкольного возраста, и превращает слуховые тренировки в интересную для ребенка познавательную игру.

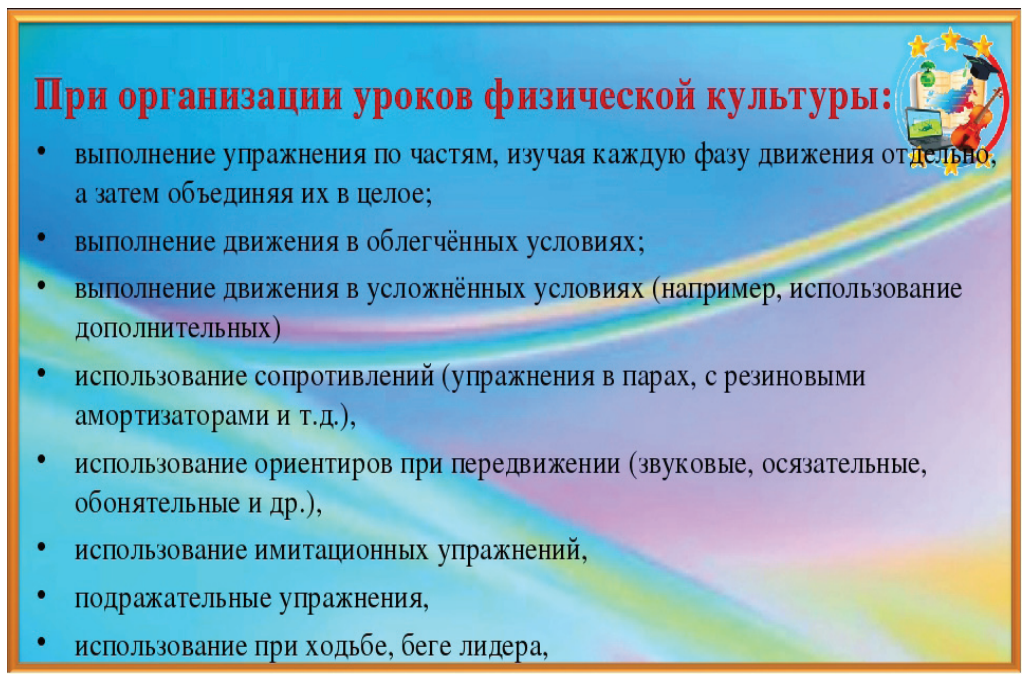

Особенности работы со слабослышащими детьми дошкольного возраста

Слух имеет огромное значение для развития человека. У ребенка, лишенного слуха, познание окружающей действительности крайне затруднено. Ребенок не сможет самостоятельно научиться говорить, так как не воспринимает речь, не слышит звуковых образцов для подражания..

Нарушения слуха могут быть врожденными и приобретенными. Врожденные нарушения слуха встречаются значительно реже (в 25\% случаев), чем приобретенные.

Среди причин, вызывающих приобретенные недостатки слуха, основное место занимают инфекционные заболевания, перенесенные в грудном и раннем детстве. Так мировая практика показывает, что на 100000 новорожденных рождается 3-5 детей с врожденными нарушениями слуха, а к 10 годам подрастания просматривается достаточно большое количество учащихся, которые нуждаются в специальном использовании физических упражнений в интересах образования и воспитания детей.

Глухота в раннем детстве бывает абсолютной в исключительных случаях. Обычно остатки слуха позволяют воспринимать отдельные очень громкие, резкие и низкие звуки, однако разборчивое восприятие речи обычной громкости невозможно.

Отдельную группу, в отношении формирования речи и ее восприятия составляют позднооглохнувшие. У таких детей может быть разная степень нарушения слуха и также разный уровень сохранности речи. При этом у рано оглохнувших детей резко ограничена возможность овладения словесной речью, что приводит в последствии 
к глухонемоте, так как ребенок не может разборчиво воспринимать чужую и собственную речь, подражать окружающим.

Глубокое и стойкое нарушение слуха оказывает отрицательное влияние на психическое, физическое и личностное развитие ребенка. Главной и наиболее трудной задачей воспитания и обучения глухих детей является формирование у них словесной речи и речевого мышления.

В отличие от глухих детей, слабослышащие обладают остаточным слухом, что можно достаточно эффективно использовать в процессе занятия физической культурой, для общения с окружающими и познания мира. Здесь также возможна корректировка, набор и овладевание речевым запасом. При применении адаптивных методик физического развития и работе с такими детьми надо также учитывать и степень снижения слуха (легкая, умеренная, значительная или тяжелая) и длительность этого снижения.

Речь слабослышащих имеет свои особенности. Ребенок какие то звуки не улавливает совсем, другие не воспринимает как здоровые люди на 100\%. Так он искаженно слышит слова, и искаженно их воспринимает, что в дальнейшем затрудняет и произношение и написание. Дети легко путают предметы и действия и близкие по звучанию слова, что также влияет на их неспособность заниматься в обычных школах. При этом своеобразие речи слабослышащих детей следует рассматривать не столько как недостаточность, сколько как процесс замедленного поступательного развития речи, подчиненного особым закономерностям.

Зачастую окружающие речевые затруднения слабослышащих детей воспринимают как рассеянность, невнимание и даже как интеллектуальная недостаточность. Ребен- ка зачастую ругают, а иногда и наказывают за упрямство, неграмотность, лень, не понимая истинных причин такого поведения. В результате такого неправильного отношения к ребенку вызывает у него отрицательное поведение (нерешительность, плаксивость, замкнутость, неуверенность, раздражительность, негативизм). Поэтому обязательным условием успешного развития слабослышащих детей является правильное организованное воспитание, где большую роль уделяют физическому развитию.

В работе с такими детьми важно выработать и использовать имеющийся уровень речи и слуха для общения, на основе которого строится вся коррекционная работа. Это может быть язык жестов и мимики, который находит педагог совместно с родителями. Необходимо обогащать сенсорное восприятие малыша, включая в совместную деятельность любой способ опосредования, стараться находиться в зоне его видимости, попутно громко и четко произнося все действия.

Также важно включать такого ребенка во взаимодействие со сверстниками. Смысл коррекционной работы для ребенка с нарушением слуха заключается в том, чтобы создать такие условия для его развития и обучения, которые позволят расширить и качественно изменить доходящие до него внешние воздействия, изменить количественный и качественный состав речи, то есть заменить акустические воздействия на равные им по значению. Здесь также кроме физических упражнений и адаптивной гимнастики и массажей, необходимо обучать ребенка чтению, научить читать с губ, жестов, выполнять действия по подражанию, использовать символы - опоры.

Так как работа по развитию слухового восприятию и обучению произношения образует целостную взаимос- 
вязанную систему, специальные формы работы на всех этапах обучения оказываются едиными. Это также индивидуальные занятия по развитию слухового восприятия и обучению произношения слов. Очень хорошо использовать методику и систему игр. Здесь также надо выделить важность занятий на музыкальных инструментах, где осуществляется систематическая работа по развитию и корректировки слухового восприятия звуков и музыки. Данная работа имеет большое значение как для эмоционального, так и эстетического развития слабослышащих детей.

Разнообразие методических приемов при обучении различию и опознаванию речевого материала имеет важное значение для детей дошкольного возраста, и превращает слуховые тренировки в интересную для ребенка познавательную игру.

\section{Заключение:}

1. В практике организации учебно-воспитательной работы с учащимися часто встречаются понятия: «вражденный» и «приобретенный» недуги, что оказывает влияние на содержание всех видов деятельности педагога.

2. Необходим подбор серии упражнений и физической нагрузки для слабослышащих детей, дающий возможность усилить процесс реабилитации, в процессе игровой деятельности.

3. Все вышесказанное дает основание внести предложение по совершенствованию профессиональной подготовки специалистов, работающих в специальных учебных учреждениях с данной категорий слабослышащих детей.

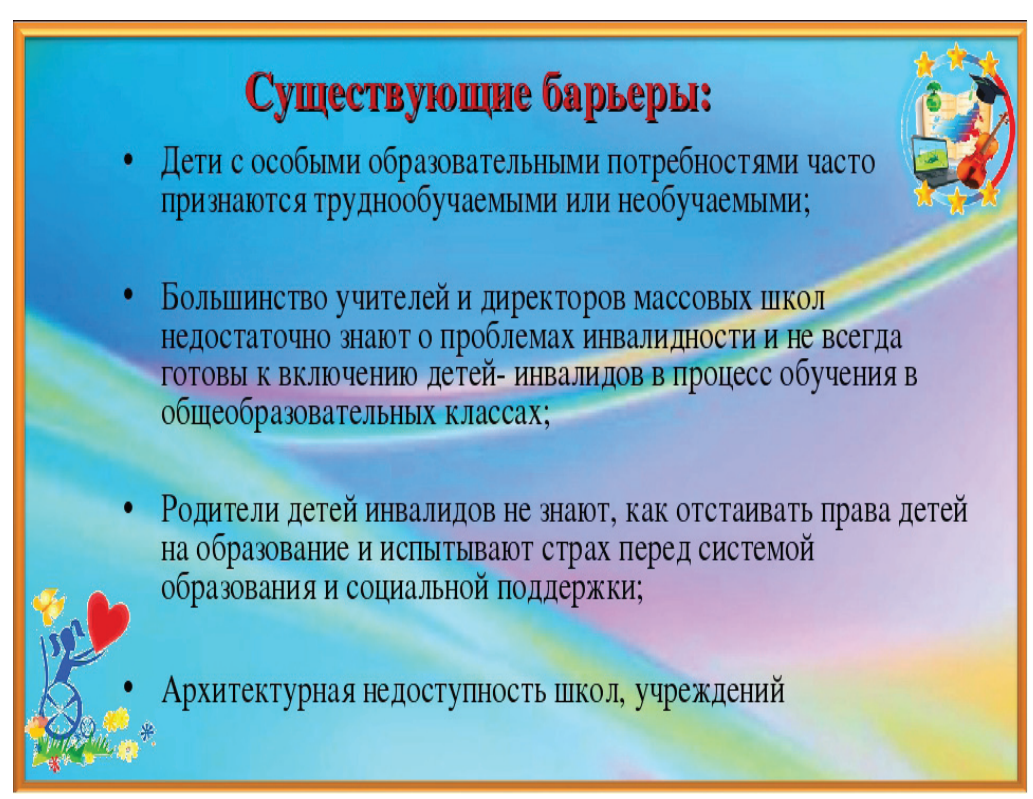

Дети с особыми образовательными потребностями часто признаются труднообучаемыми или необучаемыми;

Большинство учителей и директоров массовых школ едостаточно знают о проблемах инвалидности и не всегда готовы к включению детей- инвалидов в процесс обучения в

Родители детей инвалидов не знают, как отстаивать права детей 作

Архитектурная недоступность школ, учреждений 


\section{Лекционное занятие 12-ое}

Тема: Девиантное поведение детей и подростков как психолого-педагогическая проблема.

Особенности физического воспитания детей с девиантным поведением.

\section{План}

1. Девиантное поведение как понятие в педагогике и психологии, Особенности работы с этой категорией учаихся;

2. Умениея и навыки работы с детьми склонными к девиантному поведению.

3. Социально-психологический портррет учащихся с девиантным поведением. Подвижные игры и нормативы применяемые в процессе работы;

4. Особенность методики воспитательной работы с детьми и подросткамисками склонными к девиантному поведению.

\section{Литература:}

Старинин Ю.Л. и др. Твой спортивный уголок. - М., ФиС, $1989 ; 2$. Жищенко А.Н. Коррекция и развивающие упражнения для детей с нарушением интеллектуального развития. - Уральск, 2009, стр.56; 3. Бирюков А.А. Классический массаж. - М., Знания, 1989; 4. Щуркова Н.Е. Классное руковдство: игровые методики. - М., Педагогич. общств России, 2002.Общие основы лечебно физической культуры. В кн: Лечебная физическая культура. - М., Владос, 1998, стр.13.

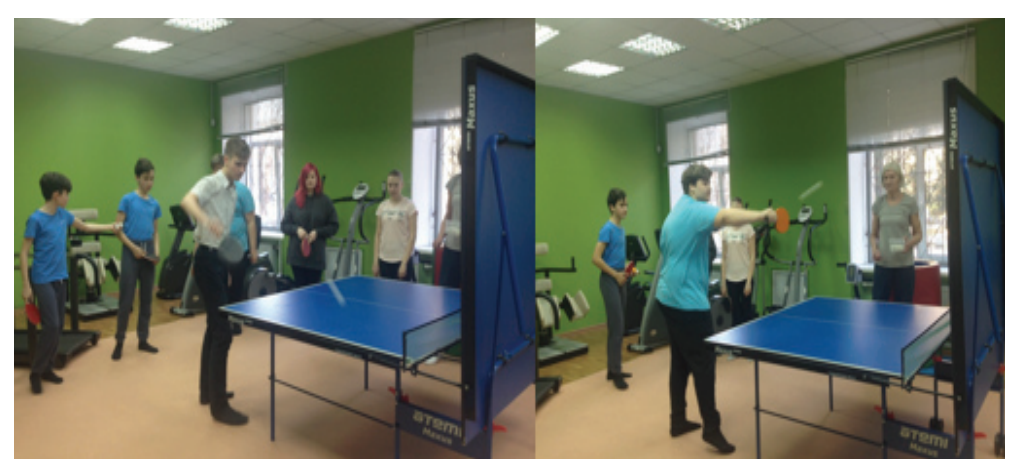

Лекционное занятие 13-ое.

Тема: Физическое воспитание в специальных школах при заболеваниях сердечно-сосудистой системы (ССC).

План:

1. ССЗ как наиболее распространенный вид заболеваний встречающийся при занятиях физическим воспитанием;

2. Наиболее распространенные виды СС3 ;

3. Физические упражнения как наиболее эффективное средство п.рофилактики и лечения СС3;

4. Рекомендации для практики работы учителям и спортивным тренерам.

\section{Литература:}

1. ЛФК при заболеваниях ССС. В кн: В.И. Дубровский. Лечебная физическая культура. Учебник, - М., Владос. 1999, стр. 199. 
Статистические данные последних лет дают основание утверждать, что ССЗ занимают одно из лидирующих мест среди заболеваний в мире. И более того статистики сообщает, что эти заболевания нарастают. В практике физического воспитания, а особенно, при занятиях спортом высоких достижений эти заболевания встречаются наиболее часто. Среди достаточно большого количества различных заболеваний в практике физического воспитания встречаются: повышенное или пониженное артериальное (кровяное) давление, гипертония и гипотония, нарушение ритма работы сердца - аритмия, стенокардия - болевые ощущения в области сердца, ишемическая болезнь сердца и др. Замечено, что смерть настигает больных в самом творческом возрасте ( 45 - 64 года). Характерными примерами стенокардией, например: приступообразность и кратковременность приступов боли в области сердца. Наиболее распостраненными лекарственными препоратами являются валедол и нитроглицерин.

Основными средствами профилактики и лечения - покой, диета и массаж. при этом массаж лучше делать в период между приступами. Массажировать в области воротниковой зоны и между лопатками. Широко применяются приемы поглаживания, разминания и растирание. И.П. больного лучше всего в положении сидя за столом. Массажу подлежат также ВЕРХНИЕ конечности, сначала правая, а потом левая рука. Массаж включает 10 - 12 процедур, продолжительность: 5 - 8 минут.

Наиболее сложным видом СС3 является инфаркт миокарда, который может возникнуть из-за высокой свертываемости крови и различных видов томбоза. Инфаркт связан с резкими болевыми ощущениями в области сердца или между лопатками. После прекращения болей у пациентов наступают тупые боли и резкое ухудшение самочувствия.

Под влиянием самомассажа улучшается ток крови по сосудам снимаюся болевые ощущения.

Реабилитационный период включает три этпа:

- стационарный ;

- период восстановления ;

- поддерживающий.

Стационарный период включает массаж первоначально лежа, а потом сидя. Продолжительность 5 - 15 мин темп самый медленный.

Период восстановления проводится, как правило, в кардиологическом санатории и включает ходьбу, лечебную гимнастику и теренкуры. Общая продолжительность санаторно-курортного лечени 1-1,5 мес. Физическими упражнениями занимаются под наблюдением врача-кардиолога и методиста ЛФК.

Поддерживающий период начинается спустя $3-4$ мес от начала заболевания. Период В включает лечебную гимнастику, прогулки, езду на велосипеде, собирания грибов и ягод.

Первоначально массаж проводится два раза в сутки и имеет задачу устранить болевые оущения, продолжительность 5 - 15 дей, дыхание кислородом в течение 10 -15 мин.

Все сказанное выше дает основание заключить:

1. Практика физического воспитания, тренировка в спорте высоких достижений сталкивается с сердечно- 
сосудистыми заболеваниями, которые требуют от специалистов особой подготовки;

2. Особое внимание требует профилактика. И лечение заболеваний средствами двигательной деятельности, массажными упражнениями особой целевой направленности;

3. Восстановительный период включает три этапа: стационарный, период восстановления и поддерживающий, каждый из перечисленных широко применяет массажные средства различной интенсивности (поглаживающие, растирания и разминания);

4. Наиболее сложным видом заболевания ССС является инфаркт миокарда, котоый проявляется болевыми ощущениями в области грудины и между лопатками ;

5. В числе наиболее современных методов научного исследования заболеваний ССС, поледния дсятилетия, применяются математические методы, которые дают оперативную информацию о состоянии ССC;
Лекционное занятие 14-ое.

Тема: Создание необходимых условий для самостоятельных занятий учащихся физическими упражнениями дома, по месту жительства. Самомассаж при занятиях спортом высоких достижений

План:

1. Современные ФКиС

После ревнований (1948), например, состоялось совещание, на котором присутствовал лауреат Ленинской премии, писатель Мухтар Ауэзов, гостренер по шахматам Е. Браун и др. Победители соревнований: внук Великого Абая - Искаков (Семипалатинск), Жокеев (Караганда), Каржауов (Аматинская область), Утегенов (Жамбыл) и др. были награждены памятными подарками. Совещание выработало ряд конструктивных предложений по рациональному проведению состязаний.

В Республике создана и активно работат федерация по национальным видам спорта. Например, тогуз-кумалаку, по которому проводятся республиканские турниры и международные соревнования.

В глубокой древности, в 8 - 7 вв до н.э. борцовских состязаний на территории казахских степей жили скифские племена - саки. У этих племен был обычай проводить спортивные соревнования по случаю бракосочетания и др. торжеств. По обычаю юноша должен был победить свою невесту и, в том числе, в соревнованиях по борьбе. Этот обычай сохранился в казахских степях и до наших дней. В соревнованиях разрешалось делать всевозмож- 
ные подножки, подсечки, зацепы и броски, но главное чтобы юноша устоял в состязаниях.

В дореволюционном Казахстане в национальной борьбе не существовало весовых категорий. Первоначально всех участников состязаний делили на легкую и тяжелую весовые категории. Требовался и специальный костюм участника, состоящий из трико и майки, бондажа и борцовок. Применялся и легий халат с короткими рукавами из плотной материи и плотной опояски - белдеу (красного или другого цветов). Обувь борцов не должна была иметь каблуков и рантов, шнурков и наконечников. Пояс завязывался узлом и обязательно только спереди. Перед начом схватки борцы становятся на противоположных по диагонали углах ковра. По свистку судьи соревнований участники идут на середину ковра и обмениваются ркопожатиями. Захват пояса для обеих борцов произволен.

Соревнования по «Казакша курес» в Республике стали регулярно проводится, начиная с 1938 года. Особенно массовыми были соревнования в 1948-60 годы, в которых участвовало от 130 до 200 участников. Одними из прославленных борцов в Республике считались Хаджи Мукан Мунайтпасов и Балуан Шолак (Нурмагамбет Баймурзаулы).

С 2003 года, по инициативе Агенства туризма и спорта Республики, была утверждена новая спортивная классификация. Национальная борьба - «Казакша курес» стала на начальным этапе, хорошим стартом для перехода к единобоствам по олимпийским видам состязаний.

Из числа видов средневековых состязаний казахов прочно утвердилась еще и стрельба из лука. Вид состязаний имеющий строгие, утвержденные Олимпийским ко- митетов, правила соревнований (см. подробно: Стрелы, летящие в цель). Другие виды национальной физической культуры и спорта.

Подводя итоги проведенным краеведческим исследованиям можно, видимо, заключить, что спортивная отрасль национальных видов человеческого знания несомненно прогрессирует. Возросло количество спортивых клубов и секций пропагандирующих национальные виды подвижных игр и состязаний. Появились научно разработанные виды спортивных положений о соревнованиях, методиках спортивного совершенствования и состязанийю. Наметилась тенденция включения казахских национальных игр в Олимпийскую программу, Международные региональные (Европейские, Азиатские и др.) состязания атлетов. Наиболее активно развивается казахская национальная борьба - «Казакша курес», некоторые виды конного спорта.

Выводы, которые можно сделать по этому разделу пособия, следующие:

1. Национальные виды спортивных состязаний и игр (Кокпар, байга, казакша курес, кыз-куу, тогыз кумалак и др.) являются хорошо проверенными средствами физического воспитания, разносторонней физической и морально-нравственной, спортивно-технической подготовки участников. Корни этих видов физического воспитания населения Казахстана уходят в глубокую древность, но и в наши дни с интересом воспринимаются большинством жителей Республик Средней Азии и Казахстана;

2. Знакомство специалистов с видами национальной 
физической культуры и спортивного соперничества является необходимым компонентом профессиональной подготовки будущих специалистов, которая несет в себе большой арсенал специальных знаний, форм и методов воспитания. Способствует широкой образованности населения, морально-нравственного ипатриотического воспитания, особенно молодежи;

3. Отдельные виды народной физической культуры, спорта и туризма (жаяу-жарыс и др.) при условии грамотного использования, могут стать действенным средством всестороннего, гармонического развития личности, приобщения населения к здоровому, насыщенному интересными и полезными делами, образу жизни;

4. Полученные краеведческие данные свидетельствуют еще и о том, что в недрах национальной культуры Казахстана развивается феноменальный компонент казахстанского спорта высоких достижений - органически связанный с общей культурой Республики и ее способности интегрировать в мировой культурно-созидательный процесс.

\section{Лекционное занятие 15-ое.}

\section{Тема: Гимнастические комплексы на дачных участках и их роль в активизации физической подготовки детей с отставанием в умственном развитии.}

План:

1. Использование физических упражнений и комплекслв специализированного массажа для ликвидаций последствий от перенесенного основного заболевания;

2. Создание условий для реабилитации заболеваний по месту жительства и на дачных участках.

3. Роль профессиональных знаний по ЛФК для работы с родителями учащихся;

4. Некоторые практические рекомендации для совершенствования профессионального самообразования будущих специалистов.

Лuтература:

1. Старинин Ю. П, и др. Твой спортивный уголок. М., ФиС, 1989, стр.143;

2. Щуркова Н.Е. Классное руководство: игровые методики. Издание 2-ое переработанное и дополненное. - М., Педагогич. общество России. 20002; 3. Классический массаж. - М., Знание, 1998, стр. 62 -65; 4. Дубровский В.И. Лечебная физическая культура. Учебник для студентов вузов - М., Владос, 1998.

Цель данного раздела учебно-методического пособия - дать специалистам отчетливые, представления о возможности продолжения оздоровления и физического са- 
мосовершенствования учащихся по местам жительства. Эти рекомендации касаются и учаащихся с ограничкееыми возможностями. Авторы рекомендаций, исходили из представлений, что далеко не каждая семья может выделить отдельную жилплощадь, закупить тренажеры, изготовить приспособления для занятии двигательной деятельностью индивидуально.

Поэтому приспособленные помещения должны отвечать достаточно жестким специфическим возможностям и требованиям: органично вписываться в общий интеръер квартиры, быть компактными, легко разбираться и быстро собираться, иметь красивый внешний вид, быть безопасными во время занятий, эффективными в деятельности, транспотирови.

В целях безопасности занятий на гимнастических комплексах авторы рекомендаций советуют изготовленияматрасики и постелить их на пол. Для изготовления матрасика (маты) размеров 80 х 80 см., под которые можно использовать лист поролона толщиной 3 х 4 см. Успешным заменителем в этих случаях может быть коврик для ванных комнат, который можно приобрести в хозяйственных магазинах. Наиболее простым вариантом набора комплекта гимнастических снарядов

применяемых на доманашних занятиях особенно с учащимися младших возрастов могут быть гимнастницы («Шведские стенки»), гимнастические шесты и канаты для лазания, гимнастические кольца и трапеции, которые без особого труда могут превращаться в качели для младших членов семьи, подвесные ерекладины , трапеции

Подобный набор гимнастических снарядов может быть успешно создаваться усилиями представителей старших поколений семьи и, до некоторой степени, упражнениях, лечебных физических упражнений. (ликвидировать потребность учащихся в движенх, развлекательных см. рис).

Спортивно-гимнастический комплекс по месту жительства учащихся.

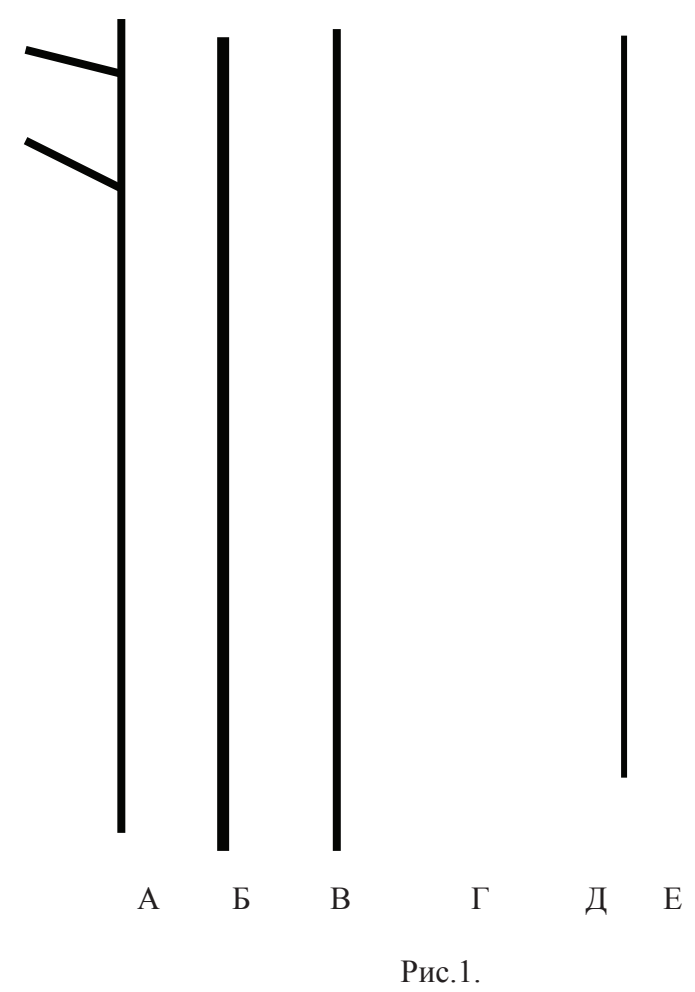

Рис.1. Пояснения: А) Лестница. Б) Шест. В) Канат. Г) Кольца. Д) Трапеция, качели. Е) Перекладина извливается из пдручного материала, например, б/у водопроводных труб. Вся конструкция крепится за стены. 
Замечено, что изготовление гимнастических компсов может роизводися и крепится к стенам выделенного помещения, комнаты.

К числу упражнений, которые со временем могут быть освоены руками вверх по канату, лазание;

Упр. 2-ое. И.П. сидя на полу, ноги врозь Силой рук подтянуться, ноги в положении угла 90 градусов. Лазание по шесту, канату различныов способами.

Массажные процедуры с помощью физических упражнений, желательно, осуществлять на специальных покрытиях по рекомендациям специалистов, описанных в пособиях. Особое внимание следует уделить упражнениям для мышц задней поверхности туловища, мышцам живота, ягодиц, бедер.

Особое внимание следует уделить упражнениям с гимнастической палкой, которые укрепляют связочный аппарат плечевых суставов. Например, из положения сидя на полу с вытянутыми вперед ногами. Руки хватом за концы палки, лежащей на бедрах , подтянуть ноги к себе, согнуть их в коленях. Обратной последовательностью движений вернуться в исходное положение.

При занятиях спортом, особенно спортом высоких достижений не всегда можно воспользоваться услугами квалифицированного массажиста. Эти специалисты, как правило, имеют персональную запись и попасть к ним на прием достаточно сложно. Обстоятельствазаставляет спортсменов осваивать основные приемы самомассажа самостоятельно и регулярно пользоваться ими при посещении бани (сауны), душа, в туристическом походе, по- сле специализированной утренней гимнастики (утренней тренировки). Самомассаж назначается индивидуально при некоторых травмах и характерных заболеваниях.

Например, применение физических упражнений в лечебных целях является средством сознательного вмешательства в процесс нормализации функций. У больных, например,сердечно-сосудистой системы вызывает поток импульсов от потока сердечной ышцы, органов дыхания легких и др.ышцы.

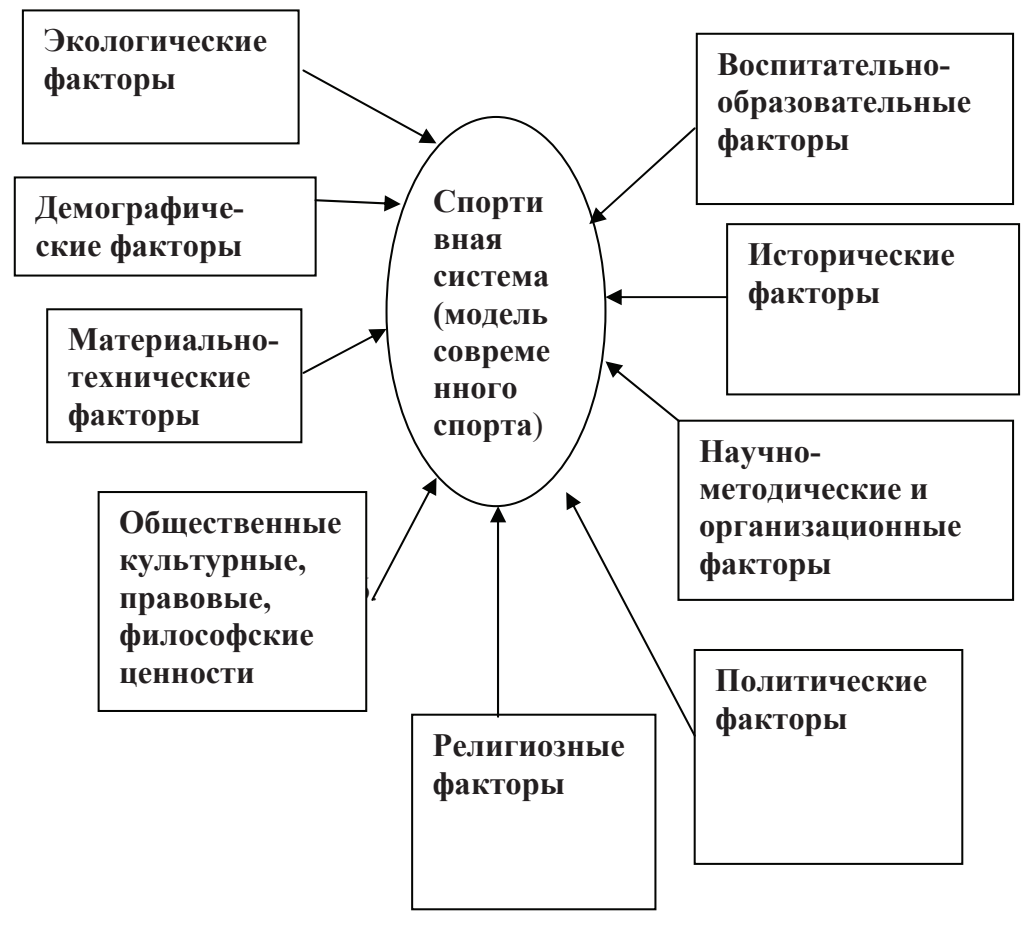


Особенно эти показатели просматриваются после пенесенных параличей.

Массаж при вялых параличах имеет некоторые особенности. К этому можно отнести состояние, когда массаж проводят в возможно более ранний период, при нормальной температуре и при отсутствии менинкеиальных синдромов. Рекомендуется применять приемы растирания, встряхивария. Массаж продикими штрихами и при обязательном пассивном движении суставов конечностей. Продолжительность процедуры 10-15 мин, ежедневно.

Приступая к массажным процедурам, специалист доджен помнить, что существуют и противопоказания к деятельности. Массаж не показан при следующих заболеваниях: воспалениях головного и спинного мозга его оболочек; расстройствах функций тазовых органов, склерозе мозговых сосудов с наклонностью к тромбозам и т.п.

К числу анализа передового педагогического опыта уместно привести результаты регионального исследования группы учителей СОШ №24 г. Уральска, который возглавляет учитель А.А. Сорокина. Эти энтузиасты избрали предметом своего исследовательского поиска упреждение и исправление сутулости учащихся. Сосредоточив внимание на использовании физических упражнений против распространенного в наши дни заболевания позвоночника - сутулости учащихся, особенно, в переходном школьном возрасте. Острота проблемы подтверждается диаграммой искривления позвоночника у учащихся на примере Республики Казахстан (см. рис.2.).

Говоря об особенностях названного пособия подго- товленного для учителей и спортивных тренеров, заметим, что в нем широко использованы краеведческие сведения, например, опыт работы с учащимися имеющими задержки в умственном развитии - умственно отсталых (УО) учащихся, когда наиболее эффективным средством воздействия на личность становятся двигательные действия, подвижные игры тематического содержания. Например, математические, географические, литературные, или исторические эстафеты. Убедительно звучат и примеры инновационного характера, Например, опыт Детского садика «Колобок». Заведующая - О.Н. Кунакова, где широко был использован опыт московского профессора А.А. Остапца-Свешникова, предложившего туристические микро-маршруты воспитанникам старших групп детского сад «Колобок». Маршруты, сочетающие двигательную, развивающую и познавательную деятельности.

С отчетливой практической направленностью звучат, по нашему мению, темы: «Адаптивная физическая культура», Физическая культура по месту жительства», «Физическая культура на дачных участках» и т.п..

Результаты всех видов опроса (устного, письменного и с помощью анкет) социологического интервью выявлено наиболее четкие отношения испытуемых к самой проблеме изучения. Отвечая на вопрос анкеты: - Kaк $B b$ очениваете роль ЛФК в содержании прочесса профессиональной подготовки специалистов? Большинство испытуемых (42 процента) ответили, что они всячески одобряют расширение роли двигательных действий особенно с лечебно-профилактической направленности. Готовы освоить реабилитационную роль физических упражнений (двигательных действий) применительно к 
конкретному виду заболевания, (глухоте, слепоте, девиантности поведения или умственной отсталости и т.п.). Высшей ступенью результативности подготовки занимающихся могли бы, по их мнению, быть готовность принять участие испытуемых в паралимпиадах современности соответствующих требованиям МОК - Международного Олимпийского Комитета». Были и другие мнения - 38 процентов.

Все сказанное выше позволяет заключить:

1. Учебно-воспитательный процесс по физической культуре и спорту специальных школ для детей и подростков с ограниченными возможностями (глухих, слепых, умственно отсталых, сутулых, с девиантным поведением и с искривлением позвоночника.) носит отчетливый направленный характер. Процесс, который в большей степени напоминает лечебно-профилактические мероприятия направленные на ликвидацию симптомов конкретного заболевания и может быть объединен общим понятием - «Лечебная физическая культура».

2. Актуальность положительного решения проблемы показатели, к сожалению, все нарастающим процентом детей и подростков носителей симптомов интеллектуального недоразвития или его последствий.

3. Данные обстоятельства предполагают высокий уровень профессионализма специалистов владеющих методикой воздействия на личность средствами двигательной деятельности, физической культурой и спортом.

4. Это обстоятельство требует значительного повышения профессиональной компетенции, профессиональ- ного мастерства специалистов подготавливаемых в вузах, на специальных факультетах.

5. ЛФК в данном понимании становится действенным средством профессиональной компетенции кадров учителей и спортивных тренеров. Содержание курса должно обстоятельно изучаться на всем протяжении профессиональной подготовка квалифицированных кадров.

6. Воздействие физических упражнений многогранно и может быть представлено на рис.4.

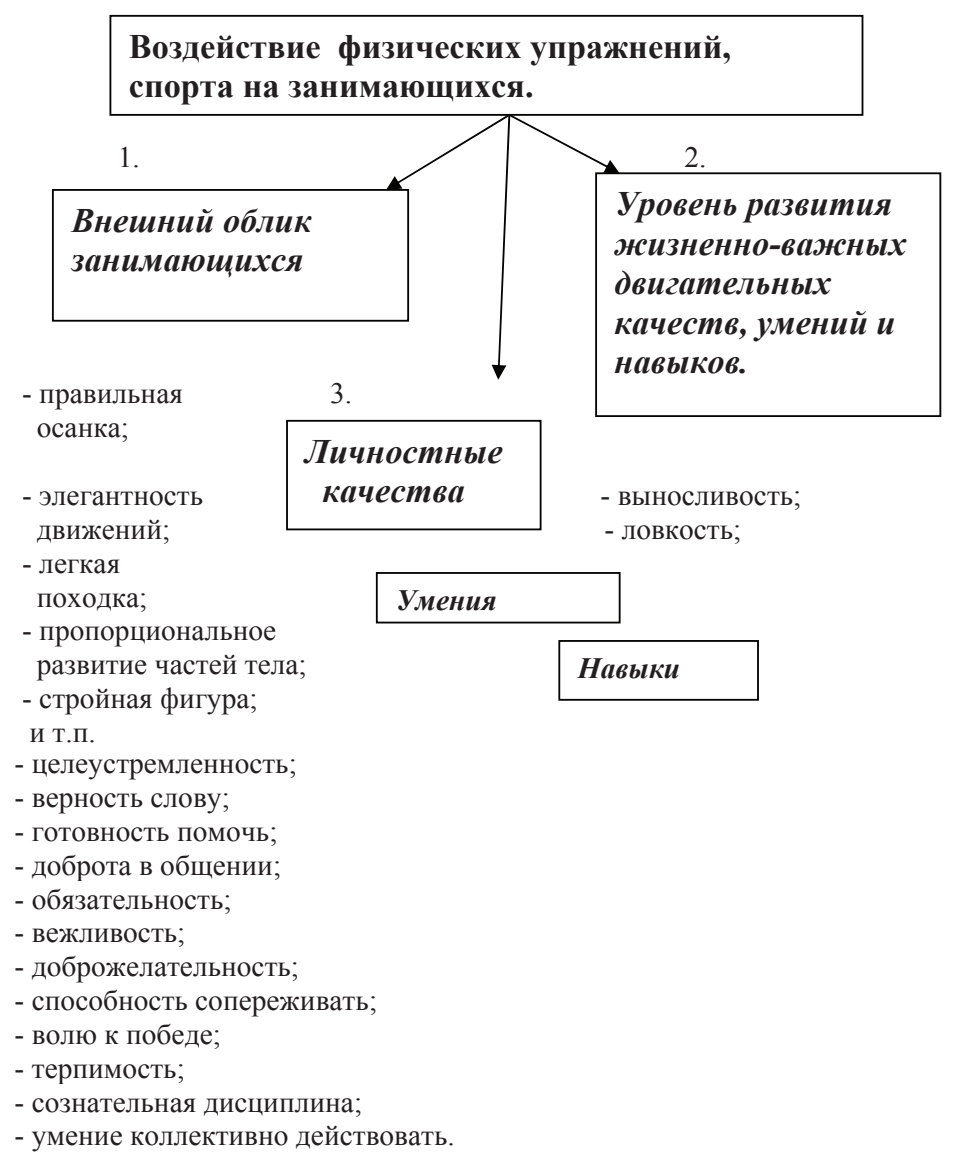




\section{Лекционное занятие 16-ое.}

\section{Тема: Спортивно-педагогические, научные кадры} Западного Казахстана: от постановки проблемы к ее решению.

\section{План:}

1. Квалифицированные кадры учителей, спортивных тренеров, научных работников - основное условие высокого уровня преподавания предмета - «Физическая культура»;

2. Учитель школы и попытки нетрадиционного подхода к обучению и воспитанию учащихся;

3. Научные кадры Республики обучаемые в центральных вузах страны;

4. Основные направления научных исследований в диссертациях ученых педагогов казахстанского Приуралья.

\section{Литература:}

Абдрахманова Р.Л. О развитии народного образовании Уральской области по отчетам военных губернаторов. В сб: Материалы международной научно-практической конференции «Проблемы и перспективы подготовки педагогических кадров на современном этапе». Научный журнал, 2010, №1(12), стр.129 - 135; Адельбаева Н.А. Учительские кадры в Казахстане в X1X в.: К постановке проблемы. Там же. Стр. 118 - 121; История физической культуры и спорта Республики Казахстан. Авторысоставители: Даупаев М.О. и Пересветов Н.Н. - Уральск, 2014; Пересветов Н.Н. и др. Внешкольные воспитательнообразовательные учреждения спортивного профиля.
Учебно-методическое пособие. - Уральск, 2008, стр. 135 - 139 Пересветов Н.Н. Воспитание движением: от идеи к реальности. В сб. Вестник Западно-Казхстанской академии. Научный журнал. 2008, стр. 50 - 53: Лесгафт П.Ф. Семейное воспитание ребенка. Часть 3. - С-Петербург, 1912, ст.

Цель данного сообщения - выявить динамику методической и научной мысли педагогов республики, Западно-Казахстанской области, в частности, в краеведческом аспекте знания. А на этой основе внести обоснованные предложения по совершенствованию процесса подготовки научных кадров специалистов по ФКиС на ближайшую и отдаленную перспективы.

Задачи исследования:

1. Проследить за состоянием народного образования области в средневековый, новый и новейший периоды истории развития общества по литературным источникам;

2. Обобщить тенденции развития системы подготовки физкультурных кадров на примере ведущих вузов Республики;

3. Внести обоснованные предложения по совершенствованию процесса подготовки физкультурных кадров для СОШ и внешкольных учреждений физкультурноспортивной направленности (ДЮСШ, СДЮСШ, Школы Олимпийскоо резерва, сборных команд областей и республики, Олимпийских сборных и т.п.).

А теперь, по-порядку! 


\section{Уважаемые Коллеги!}

Литературные источники последних лет сообщают, что до 1920 года в состав Уральской (ныне ЗКО) входили территории и нынешней Атырауской (бывшей Гурьевской) области. Образование, как свидетельствуют источники, на этой обширной территории развивалось крайне медленно. Существовали типы учебных заведений, готовящие кадры учителей, созданные еще при «Царегорохе». Эти учебные заведения определялись не только политической и социально-экономической структурами, потребностями общества, но и национальными особенностями населения, достаточно высоким уровнем его религиозности, низкой образованностью, отсталостью.

$\mathrm{H}$ аселение региона того времени состояло из четырех основных национальных групп: казахов, русских переселенцев, пришлых русских и казаков. По вероисповеданию население состояло из двух главных групп (канфессий): мусульман и христиан.

Архивные данные сообщают, что в области функционировали различные типы образовательных учреждений. Из отчета губернатора региона за 1903 год следовало, что общее количество учебных заведений в регионе составляло - 252, в которых обучалось 8838 мальчиков и 3603 человек девочек. Анализ материалов показывает, что рост числа населения значительно опережал рост количества школ. Это приводило к переполнению классов, снижению возможности обучаться всем желающим, особенно девочкам.

Единственным учебным заведением в регионе выпускающим специалистов с основательной педагогической подготовкой были сельскохозяйственные школы, пе- реименованные в последствие в сельскохозяйственные училища. Такое училище существовующее в регионе и носило имя Российского Императора - Николая 11, где были введены курсы преподавания по педагогике и психологии, дидактике, школьной гигиене и т.п. Большинство оканчивающих, курсы этого училища поступали учителями на работу в войсковые начальные учебные заведения. Однако анализ их дальнейшей деятельности показал, что эти учителя предпочитали работать по своей основной специальности - в сельском хозяйстве. Или, при возможности, поступать на учебу в средние сельскохозяйственные учебные заведения, в военные учебные заведения (юнкерские школы). Становились кадровыми военными.

Основной причиной этого явления были: низкое общественное положение учительства, его крайне низкое материальное обеспечение, бытовая неустроенность, а в итоге и низкий престиж пофессионально-педагогической деятельности специалистов, системы образования в целом.

К сказанному стоит дополнить, что наряду с войсковыми школами в регионе функционировали 37 церковноприходских и 30 школ грамоты, в которых обучались 3342 учащихся (1608 мальчиков и 1734 девочек). Количество учителей работающих в этих учебных заведениях составляло 175 человек (130 мужчин и 45 женщин). В числе проблем, как и ранее, оставались низкий уровень учительской подготовки, незаинтересованность учителей в дальнейшем профессиональном росте. В связи с чем, учительские должности замещались малоподготовленными людьми с заработной платой 120 - 180 рублей в год. А это было значительно ниже среднего заработка 
общероссийского показателя.

В общем числе учебных заведений Уральской области входило и семиклассные реальные училища, позднее (1890 - 1891) преобразованное в духовное училища, со школой войскового хора, трубачей и певчих морского класса. Итак, в войсковых школах области, по данным на 1903 год, насчитывалось 119 учебных заведений, в которых обучалось 5231 учащихся обоего пола (3 911 мальчиков и 1320 девочек). В материальном отношении эти учебные заведения находились в более благоприятных условиях, а поэтому считались престижными.

Еще сложнее обстояло дело с учителями физкультурно-спортивного цикла. В интересах физического развития с учащимися проводились занятия гимнастическими упражнениями и на этом, практически, все заканчивалось. Общий процесс физического воспитания осуществлялся «отставными унтер офицерами за малую плату», что вытекало из резолюции Императора России - Николая 11 в ответ на специальное ходатайство.

Из этого следует, что в специальных учебных заведений готовящих кадры специалистов по ФКиС в нашем регионе практически небыло. Проблема решалась только усилиями отставных, унтерофицеров и то «за малую плату». В тоже время, в европейских и других государствах мира имелись специальные учебные заведения для подготовки специалистов по руководству занятиями в группах (немецкие «Турнеры», чешские «Соколы», американские и английские «Скауты», японски Самураи и др.

Основными учебными заведениями для подготовки научно-педагогических кадров, учителей различных специальностей для западного региона Казахстана были Оренбургский кадетский корпус, Оренбургский учительский институт, Оренбургская русско-киргизская учительская школа. Выпускники этих учебных заведений определяли уровень развития общей культуры, духовной жизни и распространения образования среди населения.

Первым, кто смог получить специальную педагогическую подготовку и сумевший в последствие проводить реформы образования в Казахстане, был казахский педагог-просветитель Ибрай Алтынарин. Его путь в педагогическую науку и практику образования был достаточно тернист.

После окончания полного курса обучения в русскокиргизской учительской школе Ибрай Алтынсарин назначается (1859) младшим толмачем (переводчиком) Оренбургского Областного правления, а с 1860 года работает в одной из маленьких школ при Оренбургском укреплении, совмещая учительскую деятельность с должностью переводчика в этом же укреплении.

Как достаточно образованный человек Ибрай Алтынсарин одновременно служил инспектором киргизских школ Тургайской области. Будучи просвещенным педагогом Ибрай Алтынсарин не мог не знать, что в это время в свет вышла монографическое исследование основоположника системы физического воспитания в России, профессора П.Ф. Лесгафта: «Семейное воспитание ребенка и его значение» - С - Петербург, 1912.

Профессор П.Ф. Лесгафт в своей монографии, с позиции теории наследственности, раскрывал все стороны становления и развития организма ребенка. Отдавая 
предпочтение воспитательной работе, которая, как правило, по его мнению, должна начинаться обязательно в семье.

Несколько позднее (уже в наше время), эта идея получила более обстоятельное разрешение в работах академика Н.М. Амосова (1984), который обратил внимание на факторы, с которыми постоянно сталкивается ребенок: постоянным накапливанием отрицательных эмоций без возможности физической разрядки, с перееданием и малоподвижным образом жизни - гиподинамией. Все это вместе взятое отрицательно сказывалось на внешнем облике растущего организма; излишнем увеличении веса - массы тела, а это приводило к отставанию развития внутренних органов (сердца, легких, печени, селезенки и др.). В итоге развивались заболевания этих органов и просто всевозможные отклонения. Учеными отмечено явление, которое позднее получило название - акселерация. Явление, которое по некоторым сведениям еще недостаточно изучено и в наши дни. И сегодня, к сожалению, нет ответа на вопрос: - Почему, например, продолжительность жизни акселерантов значительно ниже чем у людей среднего роста и веса?

К этому стоит дополнить, что определенный вклад в развитие духовной культуры казахского народа выполнил еще один титан педагогической мысли республики - Ахмет Байтурсынов (1873-1938) . Интеллект этого ученого и просветителя был настолько широк, что в его наследии остались труды по философии и педагогике, психологии и школьной гигиене. Он был в полном смысле этого слова - педагогом-просветителем, общественным деятелем, новатором, ученым.
Ахмет Байтурсынов родился в Тургайском уезде. Первоначальное образование получил в аульной школе, затем окончил Оренбургскую учительскую семинарию. Значительный вклад в науку Ахмет Байтурсынов внес в области методики преподавания родного (казахского) языка. В 1921 - 1928 годах Ахмет Байтусынов выпускает в свет первый казахский букварь на кирилице и долгие годы работает в институте народного образования, став профессором Казахского Государственного университета.

В 1929 году профессор А. Байтурсынов, к сожалению, был незаслуженно ошельмован, оклеветан и необоснованно арестован. С 1934 года А. Байтурсынов находился в заключении при ГУЛАГЕ , а позднее отбывает ссылку в Архангельской области.

В 1937 году А. Байтурсынов был вторично арестован и вскоре расстрелян (Н.А. Адильбаева), как «враг народа». Этот факт убедительно доказывает, о наличии в стране «политических репрессий», особенно, для представителей гуманитарных отраслей человеческого знания. Физического уничтожения наиболее ярких представителей передовой научной и педагогической мысли республики.

В нашем областном центре имеется мемориальная доска на старом здании банка (1912), где есть имя Есета Токсанова. Его два сына Марлен и Вилен и в наши дни живут среди нас. В бытность проректора по воспитательной работе института «Евроазия»....мне приходилось встречаться с сеьей репрессированного просветителя. Проводить некоторые воспитательные мероприятия

Отдавая дань уважения предшественникам передовой классической педагогической науки в Казахстане, мы по- 
пытаемся осветиться на примере личности представляющих физкультурно-педагогическое образование, передовую физкультурно-спортивной мысли, которая приносит ощутимый авторитет престижу государства, его позиции на мировой спортивной, Олимпийской и Азиатской аренах.

Речь пойдет об ученых-педагогах сосредоточенных в стенах открытого еще в годы ВОВ (1944) Казахского Государственного института физической культуры (ныне Казахской Государственной Академии спорта и туризма (КазАСТ).

Это учебное заведение, в разные годы возглавляли (в хронологическом порядке их руководства) Шамиль Шакирович Бекбаев, Мертай Сераливич Сералиев, Хамза Мухаметжанович Мухаметжанов, Каныбек Абдуланович Ахметов и другие высокообразованные специалисты ФКиС, которым удалось создать не только материальную базу учебного заведения, но и пригласить квалифицированные кадры из центральных вузов страны (Москва, Ленинград, Киев, Минск, Тбилиси и др).

В числе наиболее значимых исследований XX века в области Олимпийского спорта был научный поиск проведенный тренером сборной страны, экс-чемпионом Республики по легкой атлетике, мастером спорта, кандидатом педагогических наук. Феликсом Павловичем Сусловым и доктором биологических наук, профессором, заслуженным деятелем науки Казахстана Александром Давыдовичем Бернштейном. Исследование касалось особенностей спортивной подготовки команды СССР к Олимпийским играм в Мехико (Мексика, 1968).

Суть проблемы состояло в том, что г. Мехико - сролица Мексиканской республики, расположен на высоте
2240 м. над уровнем моря и, естественно, здесь наблюдалась явление гипоксии, т.е. недостатка кислорода в атмосфере воздуха.

Была поставлена_задача - научиться готовить олимпийцев СССР к выступлениям в этих, достаточно сложных условиях (гипоксии) кислородного голодания.

Исследования поводилось в горах Заилийского Алатау (близь Алма-Аты), в услових приближенных к Мехико - столице X1X Олимпийских игр, где участвовали 5531 чел. и в том числе 181 женщина.

Итог эксперимента - 2-ое общекомандное место в неофициальном командном зачете - НКЗ, завоевав 91 олимпийскую медаль. США - 1-ое место, 106 медалй.

Исследованием было доказано, что при подготовке атлетов в условиях среднегорья был выявлен эффект значительного повышения работоспособности организма за счет увеличения количества эритрацитов при спуске на уровень моря, который удерживался 10 - 12 дней.

«Спортивный Казахстан» - энциклопедический справочник (2004) сообщает об участниках за счет ув Ф.П. Суслов (1924 г.р.), ЗТКаз ССР (1959), доктор педагогических наук (1973), профессор. После окончания ГЦОЛИФКа (г. Москва) приехал в Алма-Ату, (1950) и долгое время заведывал кафедрой легкой атлетики (1953 - 1965), воспитал атлетов международного класса, чемпионов Республики В. Савенкова, Р. Чарыева, Н. Казакова, Т. Мухаметжанова и др. И все это из состава студентов КазГИФКА.

Суслов Ф.П. принимал активное участие в эксперименте в условиях среднегорья. Получил достоверные результаты для сборной команды СССР. 
Не умаляя достоинств других ученых и руководителей КазГифка остановимся на личности Кайрата Хайруллиновича_Закирьянова - крупного ученого, доктора педагогических наук, профессора. В недавнем прошлом ректора Восточно-Казахстанского Государственного Университета (1993 - 1995). В 1995 - заместителя акима ВКО, 1995 - 1998 - заведующего сектором отдела внутренней политики Администрации Президента Республики.

С 1998 года Закирьянов К. - ректор КазГифка, основатель и организатор КазАСиТ, почетного профессора Иллинийского университета (США). Президент Национального спортивного союза университетов Казахстана, первый вице-президент Ассоциации вузов Европы и Азии, академик Международной академии наук высшей школы.

Анализируя научную деятельность профессора Закирьянова К., заметим, что он, в числе первых, поднял вопрос и не только в Казахстане, но и на мировом уровне, о необходимости научиться тренерам снимать физическую и психическую напряженность у спортсменов средствами фармакологии и это на фоне всеобей борьбы с допингами, различного рода стимуляторами, повышающими двигательную активность у занимающихся спортом высоких достижений.

Ученый убедительно доказал, что объем и интенсивность современной подготовки, например, к Олимпийским или Азиатским играм настолько высоки, что превышают все разумно допустимые пределы. Спорт высоких достижений подошел к своему порогу, за которым может наступить разрушение личности. Нужны допустимые (доступные) и, в том числе, фармокологические средства для снятия напряженности. Разумного, рационального отдыха атлетам международного класса.

Муратхан Таникеев, доктор педагогических наук, профессор - человек, котрый один из первых отстоял идею правомерности «Истории физическй культуры Республики Казахстан», как самостоятеьной отрасли педагогического знания в суверенном государстве. Необходимой учебной дисциплины для специалистов ФКиС.

Эти и подобные примеры позволяют утверждать, что научный и педагогический потенциал Республики в области спорта и физической культуры, достаточно квалифицирован. В состоянии решать сложные проблемы предолимпийской подготовки атлетов. Список ученых с мировым именем работающих в КазГИФКе велик: Петр Матущак, Анатоль Кульназаров, Михаил Горанько, Феликс Грибаус, Май Уденович Хван, Михаил Ким, Турсын Мухаметжанов. КАДЫР Куанышбаев, и др.

А теперь о тех, кто двигает педагогическую науку в Западно-Казахстанской области: Байтлесова, Даупаев M.O., Войлоков А.М., Граф А.Г., Жищенко А.Н., Коломоец Н.К., Клименко Т.И., Мельников В.Л., , Пересветов Н.Н., Испулова Р.Н., Водяницкая О., А. Володин А., В. Салов В.Ю., Б. Альмуханов Б.У, Усачев Н. Собянин Ф.И. Б.А. Медресов....

А теперь несколько примеров подтверждающих дальнейший профессиональный рост кадров Западного региона. 


\section{Мельников Владимир Леонидович}

Мельников Владимир Леонидович, кандидат биологических наук (1984), доцент Западно-Казахстанского государственного университета им. М. Утемисова. Мастер спорта Республики Казахстан (1998), чемпион ЗападноКазахстанской области по полиатлону, обладатель звания Лучший преподаватель года. Он активно участвовал в конференциях (Научный руководитель - профессор В.Г. Грибан). Участвовал в спортивных баталиях на первенствах области и республики (Тренер - Ю.С. Кандрашов), с отличием закончил факультет физического воспитания Западно-Казахстанского педагогического института им. А.С. Пушкина (1975) и поступил, для продолжения образования, в Институт физиологии Академии Наук Республики Казахстан.

Автор этих строк был знаком с В.Л. Мельниковым во времена, как говорят: «от студенческой скамьи до профессорской кафедры».

Избрав для себя далеко не легкий путь, так как ему пришлось сдавать вступительные экзамены в аспирантуру, а потом и экзамен кандидатского минимума по всему вузовскому курсу: «Физиологии человека и животных». Задача, согласитесь, не из легких и под силу, пожалуй, не каждому.

Через определенное время, он (Владимир) с блеском защищает диссертационную работу на соискание ученой степени - кандидата биологических наук (1984). Становится доцентом кафедры «Теории и методики преподавания физического воспитания» родного факультета.

Мельников В.Л. самостоятельно разрабатывает курс лекций, семинарских и лабораторно-практических за- нятий для будущих специалистов ФКиС: учителей физической культуры и спортивных тренеров. Выпускает в свет собственную программу и учебно-методическое пособие: «Физиологические основы физического воспитания». - Уральск, 1988; Методические рекомендации для программированного контроля знаний по «Физиологии человека» (2003) Продолжает совершенствовать себя в области спорта высоких достижений, становится Мастером спорта Республики Казахстан (1998), неоднократным Чемпионом, Лучшим преподавателем вузов Республики (2012). Лауреат Золотой Европейской медали в области образования (2013). Десятикратный Чемпион Республики по летнему и зимнему полиатлону. Почетный деятель спорта Республики Казахстан.

В этом списке звучных титулов и регалий собралось, казалось бы , все лучшее, чего мог достигнуть обычный представитель учебно-научного корпуса университетских ученых, современный ученый-педагог, И мы приводим, в очередной раз, этот достаточно убедительный перечень заслуг в надежде на стремления молодых специалистов к достижению, а может быть и преумножении достигнутых результатов. Но самое главное и это хотелось бы особенно подчеркнуть: «современный спорт высоких достижений - интеллектуальная отрасль человеческой деятельности». И это мнение В.Л. Мельников неоднократно подтвердил.

Говоря об успехах Владимира Мельникова, мы не скроем, что эта кандидатура близка нам еще и потому, что автор данного материала был знаком с Воладимиром, еще тогда, когда он гордо восседал за студенческой партой. Уверенно выступал с докладами на студенческих научных конференциях..., сражался на спортивной 
арене за честь родной Республики.

Жищенко Александр Николаевич после окончания факультета продолжил накапливать знания и передовой опыт по проблемам на особенностях работы по воспитанию интересу к занятиям физической культурой глухих и слабослышащих детей. Подростков, детей с девиантным поведением и умственно отсталостью, задержкой интеллектуального развития, слепых и слабовидящих учащихся.

\section{Войлоков Анатолий Матвеевич.}

Усилиям этого ученого была разработана тема НИР связаннная с фомированием нтереса к занятиям ФК.

\section{Даупаев Марат Уразалиевич}

Он несколько необычно сртоил свое исследования по диссертации работе, которое было посвящено поиску путей дальнейшего совершенствования учебно- тренировочного процесса спортсменов занимающихся нациогальной борьбой «Казакша курес». К этому Даупаев М.У. добавил еще и поиск путей специальной устойчивости.

Все это позволяет сделать выводы и заключить:

1. Анализ педагогического и научного потенциала специалистов ФКиС на уровне Республики можно считать вполне способным решать самые сложные проблемы, научно-выверенной пропаганды и внедрения достижений науки в широкие слои населния, особенно молодежи;

2. На уровне ЗКО имеются весомые достижения, например, отдельных личностей (Байтлесова, Даупаев,
Жищенко, Мельников, Испулова, Клименко, Медресов и др.)

3. Анализ трудовой, научной и, особенно, физкультурно-спортивной деятельности доцента кафедры Западно-Казахстанского государственного Университета им. М. Утемисова,В.Л. Мельникова дает нам основание утверждать, что все годы после окончаниофициального курса обучения и защиты диссертации по избранной специальности, Владимир Мельников работал над собственным профессиональным самосовершенствованием. Удачно совмещая учебно-воспитательную работу со студентами с систематической собственной спортивной подготовкой в избранном виде спорта. Добился выдающихся успехов: выполнил нормативы на звание «Мастера спорта Республики Казахстан», стал десятикратным Чемпионом Республики по полеатлону. Утвердился как лучший преподаватель вузов, Почетный деятель спорта Республики Казахстан, обладатель золотой медали.

Мельников В. Л. пишет книги, выпускает научные статьи, читает лекции, продолжает участвовать в самых престижных спортивных соревнованиях современности.

4. Понимая, что ближайшая тенденция развития спорта в Республике и мире в целом теснейшим образом связана с Олимпизмом и профессионализмом, думается, вполне уместно уже сегодня поднимать вопрос о кадрах специалистов способных компетентно трудиться в этой, пока еще мало знакомой, социально-культурной отрасли. Необходимо знакомить будущих специалистов с деятельностью профессиональных менеджеров, специалистов по маркетингу способных реализовывать рекламные акции, 
поддерживать интерес к спортивной деятельности, отбирать одаренных в спортивном отношении претендентов, эффективно работать со спонсорами. Э

5. Выпущенное в свет учебное пособие для студентов, магистрантов и аспирантов: «Профессиональный спорт». - Уральск, Самара, 2015. - 124 с. является, современным исследованием, отвечающим духу времени. Литературным источником, на основе которого можно начинать подготовку компетентных специалистов, потребных для работы в новой социально-культурной отрасли физкультурно-спортивного движения - профессиональном спорте.

6. Весьма убедительными, в профессиональном отношении, являются научные и научно-методические работы доцента А.Н. Жищенко, например, «Подготовка юных спортсменов-ориентировщиков». Учебное пособие для студентов. - Уральск, 2015. Объем - 16, 25 п.л.

\section{Семннарские занятия.}

\section{Семинарское занятие 1-ое.}

Тема: Краткая история возникновения и развития ЛФК. Физическое воспитание в специольных школах.;

\section{План:}

1. Значение ЛФК в профессиональной подготовке специалистов ФКиС;

2. Роль ЛФК в практике обучения и воспитания учаихся специальных школ.

\section{Jumepamypa:}

1. Лечебная физическая культур. Учебник для студентов вузов. - М., Владос, 1998; 2. Жищенко А.Н.

Коррекционные и развивающие упражнения для детей с нарушением интеллектуального развития. Методические рекомендации. - Уральск, Полиграфсервис, 2009. 3. Лечебная физическая культура. Энциклопедический слофарь ФкС. т 2. стр.78.

\section{Семинарское занятие 2-ое.}

Тема: Краеведение, как отрасль необходимого человеческого научного знания;

\section{План:}

1. Краеведение, как отрасль необходимого человеческого научного знания;

2. Основные источники краеведческой науки ( Археологические и архивные данные, памятники изобразительного искусства и архитектуры, печатные и устные источники, статистические данные, музейные экспози- 
ции и др.)

3. Физкультурно-спортивное, туристическое краеведение, как источник необходимых профессиональных знаний для учителей, спортивных тренеров и др. специалистов ФКиС;

4. Школьные краеведческие музеи и их роль для активизации воспитательной работы с населением, особенно молодежью.

\section{Семинарское занятие 3-е..}

Тема: Методы научного исследования наиболее часто применяемые в специальных школах, физкультурноспортивном, туристическом краеведении.

\section{План:}

1. Методы исследования как инструмент для добывания и хранения научных краеведческих знаний;

2. Методы и приемы для осуществления краеведческого научности поиске;

3. Общенаучные методы исследовательского поиска и их использование в накоплении, обобщении краеведческих знаний, прежнего передового опыта;

4. Некоторые практические рекомендации по использованию методов научного исследования в современной педагогической практике воспитания и образования.

\section{Лuтература:}

Ашмарин Б.А. Теория и методика педагогических исследований в физическом воспитании. Пособие для студентов, аспитантов и др. - М., ФиС, 1978; Бережнова Е.В. и др. Основы учебно-исследовательской деятельности студентов. 3-е издание. - М., Академия, 2007, стр. 51; Бу-
бэКОМ X. и др. Тесты в спортивной практике. Перевод с немецкого. - Берлин, Москва, 1968; Ганчев Д. Изучение и формирование общественного мнения. - М., Мысль, 1983; Ильина Т.А. Педагогика. Учебн. пособие для студентов. -М., Просвещение, 1984, стр.23; Краевский В.В. Методология педагогического исследования. Программа спецкурса и семинара. - М., Управление учебн. заведений Минпроса СССР, 1986; Методы педагогического исследования. Под редакцией В.И. Журавлева. - М., Просвещение, 1972; Методы исследования в теории и методике физической культуры. В кн: Ю. Курамшина и др. Теория и методика физической културы. Курс лекций. - С-Петербургская Гос. Академия физической культуры им. П.Ф. Лесгафта, 1999, стр.10; Формы и методы изучения «своей местности». В кн: Никоновой М.А. и др. Земледелие и краеведение. - М., Академия, 2000, стр. 222; Формирование научно-исследовательской культуры спортивного тренера. В кн: Пересветова Н.Н. и др. Педагогика физической културы и спорта. - Уральск, 2015, стр.73; Пересветов Н.Н. и др. Тесты в туристской практике. Методические рекомендации для учителей, ведущим исследования по комплексным темам. - Уральск, Дастан, 1996.

\section{Семинарское занятие 4-ое}

Тема: Особенности воспитательно-образовательной работы с умственно отсталыми детьми и подростками.

План:

1.Психолого-педагогическая характеристика умственно отсталых детей и подростков. Психо-физиологические особенности детей с отклонениями в психическом раз- 
витии.

2. Основная цель и задачи воспитания, обучения умственно отсталых детей средствами физической культуры.

3. Правовое воспитание учащихся. Попытки социализации и интеграции умственно отсталых детей в жизнь современного общества средствами ФКиС.

4. Некоторые практические рекомендации по физическому воспитанию и приобщение к массовому спорту умственно отсталых детей и подростков.

\section{Лuтература:}

1. Аксенова Л.И. и др. Социальная педагогика. Под редакцией Н.М. Назаровой. - М., Академия, 2001.

2. Евсеев С.П. и др. Адаптивная физическая культура. - М., Сов. Спорт, 2000.

3. Литош Н.Л.Адаптивная физическая культура: психолого-педагогическая характеристика детей с нарушениями развития. - М., СпортАкадемПресс, 2002.

4. Ивинский Д.В. Особенности организации образовательной деятельности в специальных (коррекционных) образовательных учреждениях У111 вида и перспективные направления ее развития. В сб. Вестник Тамбовского университета. Серия: Гуманитарные науки. т. 23, №173, - Тамбов, 2018.

5. Пузанов Б.П. и др. Обучение детей с нарушениями интеллектуального развития (Олигофренопедагогика). М., Академия, 2001.

Коррекционные и развивающие упражнения для детей с нарушением интеллектуального развития. Методические рекомендации. - Уральск, Полиграфсервис, 2009.
7. Олигофрения - неразвитие сложных форм психической деятельности. Психологический словарь. Под редакцией В.В. Давыдова. - М., Педагогика, 1983.

\section{Семинарское занятие 5- ое..}

Тема: Особенности воспитательно-образовательной работы с умственно отсталыми детьми и подростками.

\section{План:}

1. Умственная отсталость и ее раль на

\section{Семинарское занятие 6 - ое..}

Тема: Инновационная деятельность воспитателей, учителей физической культуры казахстанского Приуралья: проблемы и решения.

\section{План:}

1. Учитель физической культуры в системе образования и воспитания учащихся школ всех типов;

2. Инновационная деятельность воспитателей детского сада, учителей общеобразовательных школы всех типов:

a) Деятельность педагогов-воспитателей дошкольных учреждений на примере детского ясли-сада №22 - «Колобок»;

б) Обеспечение межпредметных связей изучаемых общеобразовательных дисциплин и туризма на примере СОШ №20 - учитель Т.В. Харчева;

в) Инновационная деятельность учителей 5 - 9 кл. на примере СОШ №№ 7 и 17 - учителей В.В. Пашкина и Е.А. Кочетковой; 
г) Инновационная деятельность учителей старших классов на примере СОШ №№ 1 и 23 - учителей В.В. Новикова-Лаврова, Н.П. Панфилова и А.Г. Запрометова;

д) Активизация двигательной деятельности учащихся в режиме дня школы на примере школы-лицея № 35 - учителей В.В. Панкратовой и А. Келазева;

е) Другие краеведческие инновационные находки творчески работающих учителей-практиков, педагоговноваторов;

3.Критерии оценки деятельности учителей физической культуры работающих в общеобразовательных школах и внешкольных учреждений (ДЮСШ, ДЮСШОР, ШСМ, Центров туризма и др.;

4. Некоторые практические рекомендации по совершенствованию процесса профессиональной подготовки учителей на специальных факультетах .

\section{Лuтература:}

1. Громбах С.М. Школа и психическое развитие учащихся. М.:Медицина, 1988. 2. Амосов Н.М. Раздумья о здоровье. 3-е изд. - М.: Физкультура и спорт, 1987; 3.Бальсевич В.К. Концепция альтернативных форм организации физического воспитания детей и молодежи. // Физическая культура: воспитание, образование, тренировка, 1996, № 1, стр. 23-25; 4. Пересветов Н.Н. К здоровью - через туризм. К здоровому образу жизни средствами туризма и краеведения. - Уральск, Полиграфсервис, 2000, стр.21 - 33; 5. Пересветов Н.Н. Повышение воспитательного потенциала урока физической культуры, как одной из ступеней реализации реформы школы. Методические рекомендации для учителей. - Уральск, ОблИУУ, 1995; 6. Пересветов Н.Н. Аспекты физкультурно- спортивного краеведения. Учебно-методическое пособие. т. 2-й. - Уральск, Полиграфсервис, 2016, стр. 21 - 33 и 62 - 74; 7. Матвеев Л.П. Концепция образовательной программы «Физическая культура» для средней общеобразовательной школы. //Физическая культура: воспитание, образование, тренировка, 1996, № 1, стр. 19-22; 8. Закон Республики Казахстан «Об образовании». №319-111 ЗРК

\section{Семинарское занятие 7-ое.}

Тема: Особенности методики воспитательнообразовательной работы со слабо слышащими и глухими детьми, подростками.

План:

1. Слабослышащие и глухие учащиеся: особенности физического воспитания и физического образования;

2. Возрастные и личностные особенности детей с различными формами отклонений и использование физических упражнений;

3. Учебная и внеклассная работа с детьми имеющими отклонения в органах слуха;

4. Рекомендации по совершенствованию профессиональной подготовке специалистов ФКиС.

\section{Лuтература:}

1. Власова Т.А. и др. О детях с отклонениями в развитии. 2-е издание исправл. и дополнен. - М., Просвещение, 1973;

2. Никуленко Т.Г. и др. Коррекционная педагогика. 2-ое издание. - Ростов н/д, Феникс, 2009;

3. Теория и практика физической культуры. Лекции, - СПб, 1999; Жищенко А.Н. Коррекционные и развиваю- 
щие уражнения для детей с нарушением интеллектуального развития. Метдические рекомендации. - Уральч, 2009, стр. 68.

\section{Семинарское занятие 8-ое.}

Тема: Олигофрения, как вид недоразвития психической деятельности и роль физической куль-

туры в педагогическом процессе.

\section{План:}

1.Олигофрения, как вид недоразвития психической деятельности человека;

2.Роль физических упражнений в процессе реабилитации психических и физических отклонений в деятельности человека;

3.Рек.омендации для педагогов ведущих занятия физическим воспитанием с детьми имеющими последствия от шизофрении;

4.Требования к профессиональной подготовленности, профессиональным знаниям и умениям современных специалистов.

\section{Jumepamypa:}

Психологический словарь. Под редакцией В.В. Давыдова и др. - М., Педагогика, 1983; Олигофренопсихология. См: Краткий психологический словарь. Под редакцией Петровского А.В.. - М., Политиздат. Олигофрения - неразвитие сложных форм психической деятельности. Психологический словарь. Под редакцией В.В. Давыдова. - М., Педагогика, 1983.

Практика различает несколько видов параличей.
Массаж при вялых параличах имеет некоторые особенности. К этому можно отнести состояние, когда массаж проводят в возможно более ранний период, при нормальной температуре и отсутствии менингеальных симптомов. Рекомендуется применять приемы поверхностного поглаживания, неглубокого растирания концами пальцев, встряхивания. Массаж проводится широкими штрихами и при обязательном пассивном движении суставов конечностей. Продолжительность процедуры 10 - 15 мин, ежедневно.

Приступая к массажным процедурам, специалисты должны помнить, что существуют и противопоказания к деятельности. Массаж не показан при следующих заболеваниях: воспалениях головного и спинного мозга его оболочек; расстройствах функций тазовых органов, склерозе мозговых сосудов с наклонностью к тромбозам и т.п.

К числу анализа передового педагогического опыта уместно привести результаты регионального исследования группы учителей СОШ №24 г. Уральска, который возглавляет учитель А.А. Сорокина. Эти энтузиасты избрали предметом своего исследовательского поиска упреждение и исправление сутулости учащихся. Сосредоточив внимание на использовании физических упражнений против распространенного в наши дни заболевания позвоночника - сутулости учащихся, особенно, в переходном школьном возрасте. Острота проблемы подтверждается диаграммой искривления позвоночника у учащихся на примере Республики Казахстан (см. рис.2.). 
Говоря об особенностях названного пособия подготовленного для учителей и спортивных тренеров, заметим, что в нем широко использованы краеведческие сведения, например, опыт работы с учащимися имеющими задержки в умственном развитии - умственно отсталых (УО) учащихся, когда наиболее эффективным средством воздействия на личность становятся двигательные действия, подвижные игры тематического содержания. Например, математические, географические, литературные, или исторические эстафеты. Убедительно звучат и примеры инновационного характера, Например, опыт Детского садика «Колобок». Заведующая - О.Н. Кунакова, где широко был использован опыт московского профессора А.А. Остапца-Свешникова, предложившего туристические микро-маршруты воспитанникам старших групп детского сад «Колобок». Маршруты, сочетающие двигательную, развивающую и познавательную деятельности.

С отчетливой практической направленностью звучат, по нашему мению, темы: «Адаптивная физическая культура», Физическая культура по месту жительства», «Физическая культура на дачных участках» и т.п..

Результаты всех видов опроса (устного, письменного и с помощью анкет) социологического интервью выявлено наиболее четкие отношения испытуемых к самой проблеме изучения. Отвечая на вопрос анкеты: - Kaк Bbl оцениваете роль ЛФК в содержании прочесса профессиональной подготовки специалистов? Большинство испытуемых (42 процента) ответили, что они всячески одобряют расширение роли двигательных действий особенно с лечебно-профилактической направленности. Готовы освоить реабилитационную роль физических упражнений (двигательных действий) применительно к конкретному виду заболевания, (глухоте, слепоте, девиантности поведения или умственной отсталости и т.п.). Высшей ступенью результативности подготовки занимающихся могли бы, по их мнению, быть готовность принять участие испытуемых в паралимпиадах современности соответствующих требованиям МОК - Международного Олимпийского Комитета». Были и другие мнения - 38 процентов.

Все сказанное выше позволяет закючить:

1. Учебно-воспитательный процесс по физической культуре и спорту специальных школ для детей и подростков с ограниченными возможностями (глухих, слепых, умственно отсталых, сутулых, с девиантным поведением, с искривлением позвоночника.д. и т.) носит отчетливый направленный характер. Процесс, который в большей степени напоминает лечебно-профилактические мероприятия направленные на ликвидацию симптомов конкретного заболевания и может быть объединен общим понятием - «Лечебная физическая культура».

2. Актуальность положительного решения проблемы объясняется, к сожалению, все нарастающим процентом детей и подростков носителей симптомов интеллектуального недоразвития или его последствий.

3. Данные обстоятельства предполагают высокий уровень профессионализма специалистов владеющих методикой воздействия на личность средствами двигательной деятельности, физической культурой и спортом.

4. Это обстоятельство требует значительного повышения профессиональной компетенции, профессионально- 
го мастерства специалистов подготавливаемых в вузах, на специальных факультетах.

5. ЛФК в данном понимании становится действенным средством профессиональной компетенции кадров учителей и спортивных тренеров. Содержание курса должно обстоятельно изучаться на всем протяжении профессиональной подготовка квалифицированных кадров.

6. Воздействие физических упражнений многогранно и может быть представлено на рис.4.

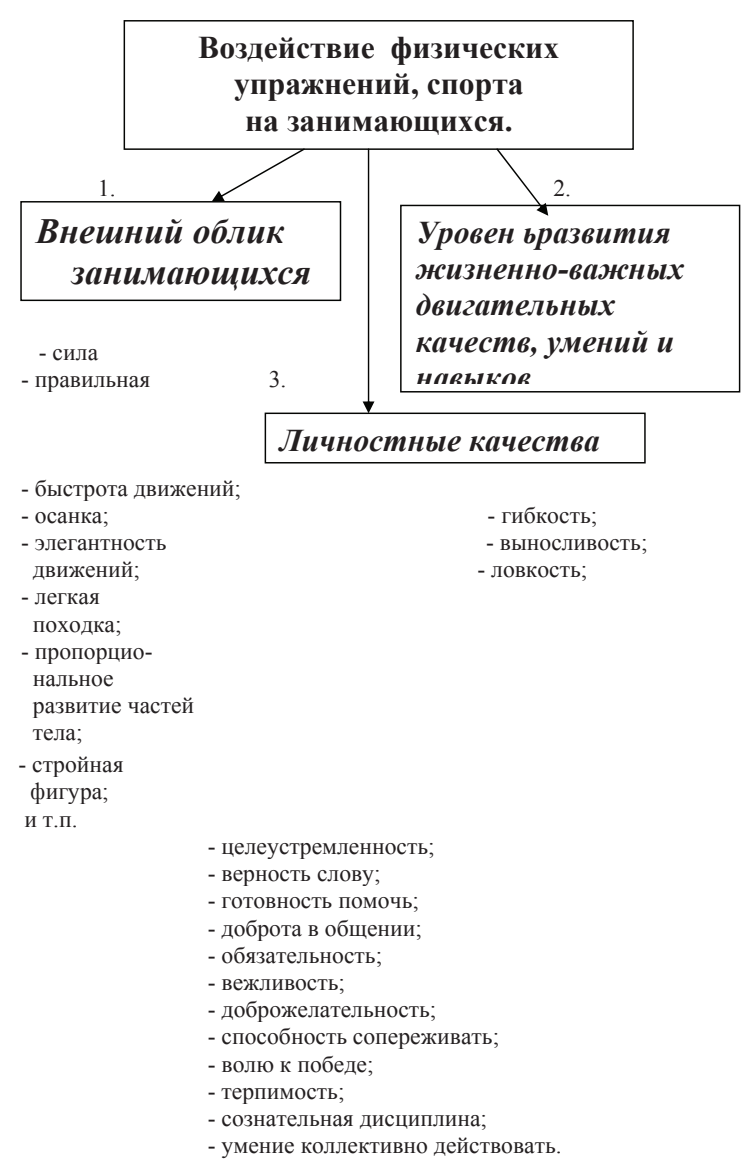

Семинарское занятие 9-ое.

Тема: Создание необходимых условий для

самостоятельных занятий учащихся физическими упражнениями дома, по месту жительства.

План:

1. «Спортивный уголок» в городской квартире: основные требования и методика изготовления и эксплуатации ;

2. Подбор и составление комплексов гимнастических упражнений рекомендуемые по месту жительства учащихся, особенно, учащихся младших классов;

3. Физические упражнения по месту жительства для старшеклассников;

4. Особенности методики профессионально-педагогической подготовки специалистов. Самомассаж в деятельности спортсменов высокой квалификации.

\section{Jumepamypa:}

1. Старинин Ю.Л. и др. Твой спортивный уголок. М., ФиС, 1989; 2. Жищенко А.Н. Коррекция и развивающие упражнения для детей с нарушением интеллектуального развития. - Уральск, 2009, стр.56; 3. Бирюков А.А. Классический массаж. - М., Знания, 1989; 4. Щуркова Н.Е. Классное руковдство: игровые методики. - М., Педагогич. общств России, 2002.Общие основы лечебно физической культуры. В кн: Лечебная физическая культура. - М., Владос, 1998, стр.13. 


\section{Семинарское занятие 10-ое.}

Тема: Создание необходимых условий для самостоятельных занятий учащихся физическими упражнениями дома, по месту жительства..

План:

1. «Спортивный уголок» в городской квартире: основные требования и методика изготовления и эксплуатации ;

2. Подбор и составление комплексов гимнастических упражнений рекомендуемые по месту жительства учащихся, особенно, учащихся младших классов;

3. Физические упражнения по месту жительства для старшеклассников;

4. Особенности методики профессиональнопедагогической подготовки специалистов. Самомассаж в деятельности спортсменов высокой квалификации.

\section{Лuтература:}

1.Старинин Ю.Л. и др. Твой спортивный уголок. - М., ФиС, 1989; 2. Жищенко А.Н. Коррекция и развивающие упражнения для детей с нарушением интеллектуального развития. - Уральск, 2009, стр.56; 3. Бирюков А.А. Классический массаж. - М., Знания, 1989; 4. Щуркова Н.Е. Классное руковдство: игровые методики. - М., Педагогич. общств России, 2002.Общие основы лечебно физической культуры. В кн: Лечебная физическая культура. - М., Владос, 1998, стр.13.

\section{Семинарское занятие 11-ое.}

Тема: Создание необходимых условий для самостоятельных занятий учащихся физическими упражнениями дома, по месту жительства, в местах отдыха. Самомассаж, при занятиях спортом высоких достижений.

План: .

1. «Спортивный уголок» в городской квартире: основные требования и методика изготовления и эксплуатации ;

2. Подбор и составление комплексов гимнастических упражнений рекомендуемые по месту жительства учащихся, особенно, учащихся младших классов;

3. Физические упражнения по месту жительства для старшеклассников;

4. Особенности методики профессиональнопедагогической подготовки специалистов. Самомассаж в деятельности спортсменов высокой квалификации.

\section{Лumepamypa:}

Старинин Ю.Л. и др. Твой спортивный уголок. - М., ФиС, 1989; 2. Жищенко А.Н. Коррекция и развивающие упражнения для детей с нарушением интеллектуального развития. - Уральск, 2009, стр.56; 3. Бирюков А.А. Классический массаж. - М., Знания, 1989; 4. Щуркова Н.Е. 


\section{ПОСЛЕСЛОВКЕ}

Уважаемые коллеги! Господа студенты!

Приглашенные товарищи, преподаватели, друзья!

Вашему вниманию предлагается сообщение: «Физичесое воспитание в специальных школах» и роль специалистов в совершенствовании процесса профессиональнопедагогической подготовки к конкретной деятельности. Итоговая часть работы - Учебно-методическое пособие предназначенное для студентов и магистрантов, обучающихся по специальности «Физическая культура и спорт».

Пособие ставит цель - подвести итог избранной достаточно сложной, противоречивой исследовательской проблемы связанной с обучением и воспитанием учащихся специальных школ. Подготовке специалистов, которым предстоит работать с учащимися, имеющими ограниченные возможности (глухие, немые, слепые, умственно отсталые, склонные к девиантному поведению, с искривлениями позвоночника и т.п.). Пособие предлагает наметить пути совершенствования процесса профессиональной подготовки кадров на ближайшую и отдаленную перспективы. Повышение профессиональной компетентности специалистов занятых в сфере «Лечебной физической культуры». Определения роли ЛФК в борьбе с разного рода заболеваниями, возникающими в бытовой и спортивной практике.

В процессе работы мы исходим из предпосылки (гипотезы, ожидаемого результата), которая сводилась к тому, что, несмотря на то, что каждая из рассматриваемых тем единого учебно-методического курса обя210 зательно предусматривала обстоятельное обсуждение на семинарских занятиях, а также наличия четко сформулированного умозаключения, выводов и рекомендаций для практики. А само послесловие, предполагает как бы прогноз автора по совершенствованию процесса профессиональной подготовки кадров на ближайшую и отдаленную перспективы. Способствует формировнию у будущих специалистов склонности к лечебнопрофилактической, рекреационно-оздоровительной деятельности преимущественно средствами физической культуры и спорта.

Данная учебная дисциплина: «Физическое воспитание в спеииальных школах» опирается на Государственную Программу по предмету и учебник - Дубровского В.И. «Лечебная физическая культура». - М., «Владос», 1998. - 608 с.: ил. К пособию приложен достаточный список рекомендованной и дополнительной литературы, собственный многолетний опыт работы автора, краеведческий опыт педагога-исследователя. базовые документы успешно дополняются Публикациями нашего земляка, доцента кафедры «ТиМФК» Государственного университета им. М., Утемисова А.Н. Жищенко, в работах которого даны примеры использования массажных процедур и других двигательных действий применительно к конкретному виду заболевания (слепоте, глухоте, умственной отсталости, девиантному поведению и т.п.).

Жищенко А.Н. Назвал свое учебно-методическое пособие: - Коррекиионные и развивающие упражнения для детей с нарушением интеллектуального развития. - Уральск, 2009. 100 с. Мы продолжили эту работу с опорой на имеющийся прошлый педагогический опыт, paнее накопленные знания. 
В данном пособии включены следующие темы. Например:

1. Особенности методики воспитательнообразовательной работы со слабослышащими, глухими детьми и подростками;

2. Особенности методики воспитательнообразовательной работы со слабовидящими, слепыми детьми и подростками;

3. Особенности использования физических упражнений при заболеваниях ДЦП - детским церебральным параличом;

4. Особенности воспитательно-образовательной работы с детьми, имеющими устойчивое девиантное поведение или находящихся в состоянии длительной гиподинамии;

5. Физическое воспитание умственно отсталых детей и подростков;

6. Механизм лечебного действия средствами физической культуры;

7. Физическое воспитание детей и подростков по месту жительства и на дачных участках;

\section{8. Другие темы.}

Общий вид подготовленного нами пособия, расположение и места изучаемых тем напоминают пятиконечную звезду, в вершинах которой названы темы конкретных лекций, которые своим присутствием раскрывают проблему в целом. Намечают оптимальные пути физической реабилитации занимающихся.
Графическое отображение планируемых тем представлено на рис. 1.

Взаимосвязь тем и разделов, представленных в учебно-методическом пособии - «Физическая культура в специиальных школах». - Уральск, 2020.

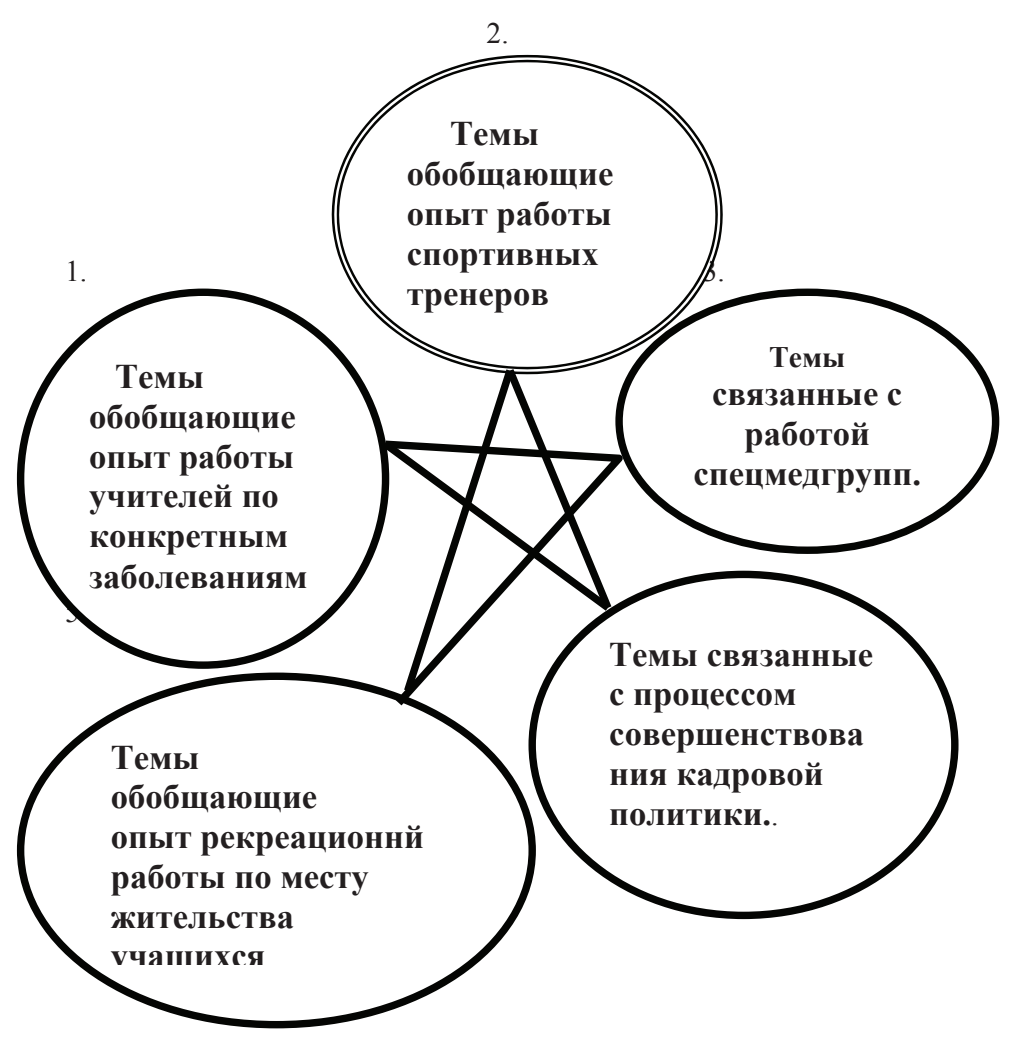




\begin{tabular}{|l|l|}
\hline \multicolumn{1}{|c|}{ УРОК } \\
\hline \multicolumn{1}{|c|}{ Физическое воспипитание в современой } \\
ощеобразовательной школе
\end{tabular}

Анализ, организация и управление физическим

воспитанием в современной общеобразовательной школе дает основание судить, что данная проблема разработана достаточно основательно. Графически этот участок может быть представлен схемой (см. рис.1.)

Итак. Цель данного сообщения - выявить оптимальные, наиболее приемлемые варианты размещения учебного материала, включенных в пособие, а на этой основе, подтвердить исследования их межпредметные связей, логика аргументированных доказательств, выводов и предложений по изучаемой проблеме, а также совершенствование практики воспитательно-образовательной и реабилитационно-рекреационной деятельности специалистов.

Беглый анализ содержания учебно-методического пособия - «Физическое воспитание в специальных школах». - Уральск, 2020. позволяет утверждать, что размещение тематики лекционного курса нами логически оправдано и закреплено, подтверждено практикой.

\section{Задачи сообщения:}

1. Литературный анализ изучаемой проблемы и обобщение существующего передового педагогического опыта;

2. Собственные исследования по поиску наиболее удобных вариантов межпредметных связей в изучаемой дисциплине;
3. Обоснованные предложения по совершенствованию процесса профессионально-педагогической подготовки учителей специальных школ;

Пытаясь ответить на вопросы связанные с актуальностью изучаемой научной проблемы, историей возникновения и развитием ЛФК, как отрасли человеческого знания мы воспользовались известной формулой, которая включает в себя такие понятия: - Как данное явление возникло? - Как, оно развивалось ? - Во, что превратилось? И во что превратится в ближайшем и отдаленном будущем?

К этому еще раз заметим, что, к сожалению, количество учащихся с подобного вида отклонениями по состоянию здоровья, судя по литературным данным, постоянно нарастает (Дубровский В.И., Жищенко А.Н., Бирюков А.А., Щуркова Н.Е. и др.). Есть и другие аспекты подтверждающие актуальность избранной проблемы исследования.

Резюмируя первую часть информации, заметим, что исследования по данной проблеме не новы. Они присутствовали еще во времена глубокой древности. Так, например, уже в древние времена (Древняя Индия, Древний Египет, Древняя Греция и Древний Рим, Древний Китай и др.) широко применялись физические упражнения связанные с растягиванием, массажом, паровыми банями, гидропроцедурами, различными диетами и закаливанием. В Древней Индии, например, широко применялись дыхательные упражнения Йога, применялся массаж при лечении различных заболеваний и физических травм. Китайские медики, широко применяли систему У-шу, различные приемы вытягивания суставов, 
массаж при многих заболеваниях. Народные методики отстаивали идею профилактической медицины. Именно китайским медикам принадлежит мнение: «настоящий врач не тот кто лечит заболевания, а тот кто предупреждает болезнь». Из этого следует, что ведущая роль современной медицины и ЛФК, в первую очередь - профилактическая, когда заболевание легче упредить, чем его потом излечить. Перечень рекомендаций по использованию массажных процедур и др. двигательных действий было объединено в общее понятие ЛФК - лечебная физическая культура, которая и стала частью активной профессионально-педагогической подготовки специалистов ФКиС. Содержание курса теснейшим образом связана с именами профессоров И.М. Саркизова-Серазини, В.В. Гариневского, Б.А. Ивановского, Н.А. Семашко и др. ученых. Средствами ЛФК стали физические упражнения, спортивно-прикладные игры, дозированные восхождения (альпинизм), дозированная ходьба (терренкуры), экскурсии и туризм.

Говоря о несомненных успехах ЛФК в деле оздоровления бойцов, например, Красной армии и флота, получивших ранения, особенно, связанных с ампутацией конечностей и др. тяжкие увечия. Эта отрасль научного знания получила дальнейшее развитие в современной практике. Следует, в первую очередь, назвать годы двух Мировых войн: 1914 - 1918 годы - 1-ая Мировая и 1939 - 1945 - 2-ая Мировая (1941 - 1945 годы - ВОВ Советского народа против фашизма), малые региональные войны. Именно в этот период были отмечены массовые ранения, которые требовали применения средств ЛФК для окончательного восстановления утраченных двигательных функций организма, например, обучению навыкам обычной ходьбы, бега преодоления препятствий.

Если учесть, что среди основных методов воздействия на организм человека ЛФК располагает различными приемами, то их условно можно разделить по характеру воздействия на личность больного:

a) поглаживания, растирания и пошлепывание;

б) растирания и разминания, встряхивание;

в) рубление и поколачивание;

г) щипковые приемы и приемы скручивания;

д) растягивание и разработка суставных и контрактур;

е) Другие действенные массажные приемы

К числу обобщений работы педагогов занятых с детьми нуждающимися в обучении в специальных школах следует, видимо, попытаться дать им краткую характеристику, например, внешнего облика подростка. Его манере общения, манеры поведения и двигательной деятельности. Так, например: Детей с ограниченными возможностями по зрению можно характеризовать как застенчивых, осторожно ступающих и медленно передвигающихся, заторможенных. И наоборот, детей с отчетливым девиантным поведением мы можем характеризовать как несколько излишне активных, иногда даже не способных управлять собственными двигательными действиями, безудерженными.

Особым разделом, по нашему мнению мог бы быть раздел раскрывающий особенности работы с учащимися, отнесенными к по состоянию здоровья с специальной медицинской группе. К этой группе мы бы отнесли и раздел физического воспитания в условиях гиподинамии. 
Интересно мнение специалистов и в отношении подростков перенесших ДЦП - детский церебральный паралич. Это тоже часть ЛФК. Специалисты рассматривают ДЦП как полеэтнологическое (многопрофильное) заболевание. Болезнь, как свидетельствует литература, развивается в следствие, например, родовых травм с последующим кровоизлиянием в головной мозг.

Для этого заболевания типичны спазмы мышц нижних конечностей, контрактуры и другие двигательные нарушения. Нередко при этом заболевании нарушается психика больных детей. Появляется косоглазие, ухудшение зрения, слуха. Проявляются и другие функциональные расстройства.

По клиническому течению болезни выделяют раннюю и позднюю стадии ДЦП. А сама реабилитация включает, кроме медикаментозного, ЛФК, массаж, физио- и гидротерапию, различные санаторно-курортные лечения.

При всем богатом перечне средств воздействия на детей, страдающих от последствий ДЦП ведущим остается мнение - ЛФК широк: От пассивных форм движения в суставах до гимнастики и подвижных игр в воде, Перечень движений входящих в арсенал ЛФК достаточно свободного плавания и участия в соревнованиях. Рекомендуются упражнения на растягивание и сопротивление. Упражнения на развитие подвижности в суставах и позвоночные движения, терренкур (дозированная ходьба) и занятия на тренажерах.

Опыт специалистов практикующих в странах Северной Европы (Финляндия, Норвегия, Швеция, Дания, Голландия и др.) й позволяют утверждать положительное влияние ЛФК на больных ДЦП. Особое воздействие оказывают парные бани, сауны. При первых посещениях саун рекомендуется обращаться с детьми особенно мягко. Не заставлять ребенка делать что-либо насильно. Постепенно дети адаптируются к более высоким температурам, повышенной влажности и общей атмосфере приема гидропроцедур, дозировке упражнений.

Следует помнить, что продолжительность первых посещений парных бань не должно превышать 3-5 минут, а общая продолжительность процедуры - до 10 мин

После охлаждения и улучшения кровоснабжения кожи следует вновь зайти в сауну и похлестать ребенка березовым веничком. В дальнейшем дети это делают сами или с помощь родителей.

Первые сеансы охлаждения должны быть кратковременными обязательно с посещением сауны. После окончания банных процедур следует дать детям обильное питье, а при желании пищу, желательно овощи или фрукты.

Классное руковдство: игровые методики. - М., Педагогич. общств России, 2002.Общие основы лечебно физической культуры. В кн: Лечебная физическая культура. - М., Владос, 1998, стр.13. 


\section{Раздел третий}

\section{Список использованной и рекомендуемой литературы}

1. Абдакимов А. История Казахстана (с древнейших времен до наших дней) Учебное пособие. Издание 3-е, переработанное и дополненное. Книга издается в авторской редакции - Алматы: ТОО «Издательский дом «Казахстан», 2001.

2. Абусеитова М. Казахстан и Центральная Азия в ХУ ХУ11 вв. История, политика, дипломатия. - Алма-Ата, 1998.

3. Агеевец В.У. и др. Пять колец. Идеи и мораль. Умножать и развивать олимпийские традиции. - Л. Лениздат, 1985.

4. Аджи М., Полынь половецкого поля. - М., ТОО «ПикКонтекст», 1994

5. Аксельрод С.Л. Спартакиады Народов СССР. (Материалы для лектора) - М.: Знание, 1971.

6. Альмуханов Б.У. Основные понятия и термины физической культуры и спорта. Методическое пособие. - Уральск: Зап.- Каз. Гос. Университет, 2003.

7. Альмуханов Б.У. Основные понятия и термины физической культуры и спорта. Методическое пособие. - Уральск: Зап.- Каз. Гос. Университет, 2003.

8. Альмуханов Б.У., Ашмарин Б.А. и др. История развития физической культуры. В кн: «Теория и методики физкультурного образования: учебное пособие для вузов. - Уральск. Издательский центр и СМИ ЗКГУ им. М. Утемисова, 2011, стр. 7 - 20.

9. Антология социально-политической мысли Казахстана с древнейших времен до наших жней. В двух томах. - Алматы: Институт развития Казахстана, 2002.

10. Амангалиев 3.А. Елагин А.С. Оборона Уральска. Алма-Ата, 1991.

11. Анастази А. Психолого-педагогическое тестирование.
Книга 1. - М., Педагогика, 1982.

12. Асфендияров С.Ж. История Казахстана. - Алма-Ата, 1993.

13. Асфендияров С.Ж. История Казахстана с древнейших времен. - М - Алмты, 1995.

14. Асылбеков М.X. и др. Социально-демографические процессы в Казахстане (1917 - 1980 гг.) - Алма-Ата, 1980.

15. Артыкбаев Ж.О. История Казахстана: Учебник для вузов. - Костанай: ТОО «Центрально-Азиатское книжное издательство, 2007.

16. Ахинжанов С. Кипчаки в истории средневекового Казахстана - Алма-Ата, 1989.

16. Ахметов К. и др. Олимпийские встречи. - Алма-Ата, 1961.

17. Акбай Ж. Радуга Ак-Жайык. - Самара, Дом печати, 1997.

18. Акбай Ж. Хан Жангир. - Уральск, Полиграфсевис, 2002.

19. Акбай Ж. Нас сближает степь, объединяет Урал. В кн: Урал - река жизни. - Уральск, Полиграфсервис, 2017, стр. 110 $-113$.

20. Андропова М.В. Школьная гигиена. - М., Медицина, 1970 .

21. Ашмарин Б.А. Теория и методика педагогических исследований в физическом воспитании. - М.: ФиС, 1978.

22. Ашурков В.Н. и др. Историческое краеведение. Учебное пособие для студентов. - М., Просвещение, 1980.

23. Аяган Б.Г. Наша задача - быть объективными исследователями эпохи. В сб: «Актуальные проблемы изучения истории независимого Казахстана. - Астана. Институт истории государства, 2008, стр. 27.

24. Аяган Б.Г., Абжанов Х.Н. и др. Современная история Казахстана. Учебник для студентов неисторических специальностей (бакалавриата) высших учебных заведений. - Алматы «Паритет», 2010. 
25. Байдосов К.Р. Казахская национальная борьба - АлмаАта, Мектеп, 1987.

24. Белый А.И. Старый собор в Уральске. - Уральск, 1994.

26. Белый А.И. Яицкий городок - Уральск за 400 лет. Уральск, 1993.

27. Белый А.И. Уральская осень 1833 года. К 160-летию посещения А.С. Пушкиным Уральска. - Уральск, 1993.

28. Белый А.И. Старый собор в Уральске. (Века и годы. Встречи. Легенды, Раритеры. Уральск, 1994.

29. Белорусова В.В. Тезисы этических бесед о спорте. - Л.: ГДОИФК им. П.Ф. Лесгафта, 1987.

30. Бережнова Е.В. и др. Основы учебно-иссле-довательской деятельности студентов. 3-е издание. М., Академия, 2007.

31. Боевые искусства Шаолиня. Стиль обезьяны. Си Юньтай и др. (Под редакцией В.А. Рыжова). - М.: МСП. Интерконтакт, 1990.

32. Букаткин П.Р. Западноказахстанцы в годы суровых испытаний (1941 - 1945 гг.) - Самара, 1992.

33. Букаткин П.Р. От Уральска до Эльбы и Праги. - Уральск, 1994.

34. Букаткин П.Р. Западный Казахстан - ближний тыл Сталинградского фронта. В сб: «Вклад Западного Казахстана в Победу в Великой Отечественной войне 1941 - 1945 гг.». Уральск, 2013, стр. $13-24$.

35. Брабич В. и др. Зрелища Древнего мира. - Л.: Искусство, 1971.

36. Бубновский С. М. 50 незаменимых упражнений для дома и зала. - М., Издательство «Э», 2017;

37. Брэгг П.С. и др. Позвоночник - ключ к здоровью. Санкт-Петербург, 1995.

38. Буркитбаев А. Казахские национальные виды конного спорта. (Правила организации спортивных соревнований и спортивная классификация) - Алма-Ата, Мектеп, 1978.

39. Вагин А.А. Методика обучения истории в школе. - М.: Просвещение, 1972.
40. Варакин А. и др. Тайны исчезнувших цивилизаций. М.: РИПОЛ КЛАССИК, 2004. - (Тайны, находки, сенсации).

41. Виноградов П.А. и др. Основы физической культуры и здорового образа жизни: Учебное пособие. - М.: Советский спорт, 1996.

42. Виноградов П.А. и др. Теория и методика здорового образа жизни. Учебное пособие. - Алматы, 2004.

43. Войлоков А.М. Очерки физкультурного движения в Уральском ордена «Знак Почета» педагогическом институте им. А.С. Пушкина. - Уральск, 1993.

44. Войлоков А.М. От становления физической культуры к мастерству и профессии. Под редакцией академика МАНН ВШ и МАИ Т.З. Рысбекова. - Уральск, ЗКГУ, 2002.

45. Вопросы истории и археологии Западного Казахстана. Ежегодник. Выпуск №3. - Уральск, Полиграфсервис, 2016.

46. Выдрин В.М. Введение в профессиональную деятельность. Учебное пособие для институтов физической культуры. - С-Пб., 1995.

47. Галицкий А. и др. Путешествие в страну игр. - М.: ФиС, 1971.

48. Гайл В.В. Краткая история физической культуры и спорта. - Екатеринбург УГТУ - УПИ, 2006.

49. Гескин В. М. Кто посягает на олимпийский огонь? М.: ФиС, 1986.

50. Герои Советского Союза - Казахстанцы. В 2-х томах. Алма-Ата, 1968.

51. Гик Е., и др. Популярная история спорта. - М.: Академия, 2007.

52. Гиржон С. С. Международные связи спортсменов Казахстана. - Алма-Ата, Казахстан, 1967.

53. Глэнвилл Б. Олимпиец: Роман; Рассказы (Перевод с англ.; Предисловие А. Зверева). - М.: ФиС, 1989.

54. Голощапов Б.Р. История физической культуры и спорта. Учебное пособие. - М.: Академия, 2001.

55. Гончаров В.Д. Человек в мире спорта. (Социально- 
психологические аспекты) - М.:, ФиС, 1978.

56. Горанько М.И., Кульназаров А.К. и др. Президентские тесты физической подготовленности - основа оздоровления населения Республики Казахстан. - Алматы: Аль-Фараби, 1997.

57. Горбачев А.А. и др. Основы организации туризма в Казахстане: проблемы и перспективы развития. (На материалах Западно-Казахстанской области). - Уральск, 2003.

58. Гренобль, 1968 г. Десятые зимние Олимпийские игры. Мехико. Девятнадцатые летние Олимпийские игры. - М., ФиС, 1970

59. Даупаев М.О. и др. История физической культуры и спорта. Том 1. Всеобщая история физической культуры и спорта. Под общей редакц. Б.С. Шинтимировой. - Уральск. Полиграфсервис, 2013.

60. Даупаев М.О. и др. Учитель физической культуры: процесс подготовки, опыт, теория. Учебно-методическое пособие под редакцией Б.С. Джумакаевой. - Уральск. Издательский центр и СМИ ЗКГУ им. М. Утемисова, 2010.

61. Даупаев М.О. История физической культуры и спорта Республики Казахстан. - Уральск, Полиграфсервис, 2014.

62. Даупаев М.О. Эффективность освоения техники борьбы «Казакша курес» студентами факультетов физической культуры с учетом развития функций равновесия. Канд. педагогич. диссертация. - С-Пб, 2000;

63. «Динамо». Годы становления, годы созидания.- Алматы, КазАкпарат, 2010.

64. Дубровский В.И. Лечебная физическая культура. - М., Владос, 1999.

65. Дубровский В.И. Гигиена физического воспитания. Учебник. - М., Владос, 2003.

66. Евстафьев В.В. Анализ основных понятий в теории физической культуры: материалы к лекциям и семинарам. - Л.: ВИФК, 1985.

67. Егоров В.П. Историческая география Золотой Орды в
XIII- XIУ вв. - M., 1985.

68. Ермолаева Л.К. Система краеведческой работы в школе. - СПб., 1996.

69. Ерофеева И. Хан Абулхаир: полководец, правитель и политик. - Алма-Ата, 1999.

70. Ердавлетов С.Р. История туризма. Развитие и научное изучение. Учебное пособие.. - 2-ое изд., доп. и переработ. Алматы, 2010.

71. Ерназаров Ж.Т. Семейная обрядность казахов: символ и ритуал. - Аматы, Центр истории и археологии, 2003.

72. Железняк Ю.Д. и др. Основы начно-методической деятельности в физической культуре и спорте. Учебное пособие. - М.: Академия, 2005.

73. Железчиков Б.Ф. Археологические памятники Уральской области. - Волгоград, 1998

74. Западно-Казахстанский государственный университет: история становления и развития. - Уральск, Редакционноиздательский отдел. ЗКГУ, 2002.

75. Зиманов С.3. Россия и Букеевское ханство. - Алма-Ата, 1982.

76. Иванов Г.Д., Кульназаров А.К. Физическое воспитание студентов. Учебник для студентов высших учебных заведений. - Астана, 2000.

77. Ильинич В.И. Физическая культура студента и жизнь. Учебник. - М.: Гардарики, 2007.

78. Испулова Р.Н. и др. Социальная природа современного спорта. В сб: «Актуальные проблемы физического воспитания и начальной военной подготовки учащейся молодежи». - Уральск, ЗКГУ, 2007, стр. 76 - 78.

79. Испулова Р.Н. Педагогическая практика по физическому воспитанию в школе. - Уральск, 2007.

80. История физической культуры. (Редакц. коллегия: $\mathrm{Ca}$ моуков Ф.И. (Председатель), Торопов, Н.И., Харабуга Г.Д., Чудинов И.Г.) - М.: ФиС, 1964.

81. История физической культуры и спорта. Учебник для 
ин-тов физич. культуры. Под общей редакц. В.В. Столбова - М.: ФиС, 1975.

82. История Древнего мира в художественных образах. Хрестоматия. Пособие для учителей. Издание 2-ое. (Составители О.В. Волобуев и А.В. Шестаков) - М.: Просвещение, 1978.

83. История физической культуры и спорта: Учебник для ин-тов физической культуры. Под редакцией В.В. Столбова. - М.: ФиС, 1983.

84. История физической культуры в Казахской ССР. (Составитель - М. Таникеев) - Алма-Ата, Каз. ГИФК, 1973.

85. Ищук Г.Н. Место краеведческой деятельности в школьном образовании. В сб: Вестник академии детскоюношеского туризма. - М., Просвещение, 1987.

86. Кацюба Д.В. Школьное историческое краеведение в системе подготовки студентов к краеведческой работе в школе. - М., Автореф. дисс. докт. пед. наук. АПН СССР. НИИ содержания и методов обучения. - М., 1987, стр. 3 - 4.

87. Казахстан спортивный. (Составители К.Ахметов и А. Царев). - Алма-Ата, 1969.

88. Калентьев С.А. Газета «Приуралье»: Страницы нашей жизни. Часть первая (1919 - 1940). - Уральск, Полигафсервис, 2017.

89. Калентьев С.А. Газета «Приуралье»: Страницы нашей жизни. Часть вторая (1941 - 1990). - Уральск, Полиграфсервис, 2018.

90. Кан Г.В. История Казахстана. Учебник. - 3-е изд., перераб. и допол. -Алматы: ТОО «Алматыкитап», 2005.

91. Кассиль Л. Римская считалочка. - М.: Малыш, 1964.

92. Карпушин Б.М. Педагогические основы воспитательной деятельности при занятиях физической культурой и спортом. - М.: Просвещение, 1998.

93. Каталог элективных дисциплин, - Уральск, 2008.

94. Ким В.Г. Алматы - потенциальная столица Зимних Олимпийских игр. - Алматы, Планета, 2005.
95. Ключевский В.О. Русская история. Подготовка текста Ю.М. Медведев.- М.: Эксмо, 2005.

96. Книга учителя физической культуры. Под общей редакцией В.С. Каюрова. - М.:ФиС, 1973.

97. Козыбаев М.К. и др. История Казахстана. Учебник.Алма-Ата, Атамура, 1992.

98. Коломейцев Ю.А. Взаимоотношения в спортивной команде. - М.: ФиС, 1984.

99. Константинов Н.А. и др. История педагогики. Учебник. Издание 5-ое. - М.: Просвещение, 1982.

100. Константинов Ю.С. Подготовка судей соревнований по туризму. - М., ФиС, 1985.

101. Краеведение. Пособие для учителей. Под редакцией А.В. Даринского. - М., Просвещение, 1987.

102. Кто подрывает Олимпийские идеалы (Документы, факты, комментарии). Авторы-составители: С. Попов и А. Серебницкий. - М., АПН, 1984.

103. Куда уходят чемпионы? СБ. очерков.(Составитель Л.А. Сапожников). - М.: ФиС, 1980.

104. Кудрявцев В.Г. и др. Спорт: события и судьбы. Книга для учащихся 5 - 10 классов средней школы. - М.: Просвещение, 1986.

105. Курлапов А.З. Походы и служба Яицких-Уральских казаков. 1-ый том. - Уральск, ТОО. «Sophyle». 2013.

106. Курлапов А.З. Яицкие-Уральские казаки. Повседневная жизнь и праздники. 2-ой том. - Уральск, ТОО. «Sophyle». 2013.

107. Кузембайулы А., и др. История Казахстана: Учебник для вузов. 7-ое изд. перерабо. и доп. - СПб.: Соларт, 2004.

108. Кулинко Н.Ф. История и организация физической культуры. Учебное пособие. - М.: ФиС, 1982.

109. Культурология. История мировой культуры. Учебник для вузов. Издание 2-ое. Под редакцией профессора А.M. Марковой. - М.: ЮНИТИ, 2000.

110. Кун Л. Всеобщая история физической культуры и 
спорта. (Перевод с венгерского). Под общей редакцией В.В. Столбова. - М.: Радуга, 1982.

111. Кушаев Г.А. Этюды древней истории степного Приуралья. - Уральск, Диалог, 1993.

112. Латышина Д.И. История педагогики. (История образования и педагогической мысли). Учебное пособие. - М.: Гордарики, 2002

113. Легенды и мифы Древней Греции. - М.: Астрель: АСТ, 2008 .

114. Лесгафт П.Ф. Собрание педагогических сочинений (Состав. И.Н. Решетень) - М.: ФиС, 1988.

115. Ли К.А., Фомин В.П. Краеведение и развитие туризма в Приуралье. - Уральск, Чапаевская укрупненная типография, 1969.

116. Линник В.Н. Формирование познавательных интересов учащихся в процессе краеведческой работы. Дисс. канд. пед. наук. / ЛГПИ им. А.И. Герцена. - Л., 1968.

117. Любимов Л. Искусство древнего мира. Книга для чтения.- М.: Просвещение, 1980.

118. Любимов Н.И. ХУ Олимпийские игры. - М., ФиС, 1955.

119. Матюшин Г.Н. Историческое краеведение. Учебное пособие для студентов. - М., Просвещение, 1987.

120. Методы педагогических исследований. Лекции для студентов педагогических институтов. Под редакцией В.И. Журавлева. - М., Просвещение, 1972.

121. Милоногов Н.П. Историческое краеведение: основные исторические изучения родного края. - М., 1969.

122. Мусагалиев Ш.С. Диалектика истории. (Краткий очерк). - Уральск, ЗКГУ им. М. Утемисова, 2003.

123. Назарбаев Н.А. Послание Президента Республики Казахстан - Лидера нации Казахстан - 2050. - Астана, 2013.

124. Назарбаев Н.А. В потоке истории. - Алматы: Атамура, 1999.

125. Назарбаев Н.А. Стратегия трансформации общества и возрождение Евразийской цивилизации. - М.: Экономика, 2000.

126. Накатков Ю.С. История туризма Казахстана. Учебное пособие. - Алматы, 2001.

127. Николаев Н.Г. и др. Краеведение. Пособие для учителей. - М., Учпедгиз, 1961.

128. Никонова М.А. и др. Земледелие и краеведение. Учебное пособие для студентов. - М., Академия, 2000.

129. Новое в воспитательной работе школы. - М., 1991.

130. Новоселов Н.П. и др. История физической культуры народов СССР. Часть 1-ая. Под общей редакцией С.Д. Синицына. - М.: ФиС, 1953.

131. Оливова В. Люди и игры: У истоков современного спорта (Пер. с чешского). - М.: ФиС, 1985.

132. Олимпиада-80. День за днем (Автор-составитель С.Н. Кружков. - М., ФиС, 1980.

133. Олимпийский глобус: Сб.(Сост. В.В. Кукушкин). - М.: ФиС, 1987.

134. Олимпийские игры. Маленькая энциклопедия. «Советская Энциклопедия», 1970.

135. Остапец А.А. На маршруте туристы-следопыты. - М.: Просвещение, 1987.

136. От Афин до Москвы. 2-е издание, исправленное и дополненное. - М., ФиС, 1983.

137. Очерки по истории физической культуры. Выпуск 3-ий. Сборник трудов под общей редакцией Н.И. Торопова. - М.: ФиС, 1948.

138. Очерки по истории физической культуры. Выпуск 4-ый. Сборник трудов под общей редакцией Н.И. Торопова. - М.: ФиС, 1949.

139. Очерки по истории физической культуры. (Составители: Самоуков Ф.И. и Столбов В.В.) - М.: ФиС, 1967.

140. Очерки по истории спорта в Казахстане. Часть 1-ая. Под редакцией М.Т. Таникеева. - Алма-Ата, 1979.

141. Очерки по истории спорта в Казахстане. Часть 2-ая. 
Учебное пособие. Под редакцией М.Т. Таникеева. - АлмаАта, 1980.

142. Организация физической культуры и спорта. Под общей редакцией В.У. Агеевца и Т.М. Каневец. - М.: ФиС, 1986.

143. Павлов С.П. Олимпийский год. (Итоги. Уроки. Перспективы) - М.: ФиС, 1973.

144. Пересветов Н.Н. Исследование объема умственной и двигательной деятельности студентов. В сб: Материалы XXX111 научной конференции ППС Уральского педагогического института им. А.С. Пушкина. - Уральск, УПИ, 1969, стр. $49-51$.

145. Пересветов Н.Н. О взаимозависимости физической подготовленности и умственной работоспособности студентов. В кн.: Социальные проблемы физической культуры и спорта. Под общей редакцией профессора Г.И. Кукушкина. М.: ВНИИФК, 1973, стр. $72-76$.

146. Пересветов Н.Н. Управление процессом воспитания интереса к профессии учителя. В сб.: Научные основы учебно-воспитательного процесса в педагогическом вузе. Алма-Ата, 1977.

147. Пересветов Н.Н. Повышение воспитательного потенциала урока физической культуры, как одна из ступеней реализации реформы школы. Методические рекомендации в помощь учителю. - Уральск, Обл. ИУУ, 1985.

148. Пересветов Н.Н. Изучение общественного мнения, для совершенствования пропагандистской работы в молодежных коллективах. (В помощь лектору). - Уральск, Обком ЛКСМ Казахстана, 1986.

149. Пересветов Н.Н. Формирование профессионального интереса у студентов факультета физического воспитания. В сб. : Физическое совершенствование учащейся молодежи. - Алма-Ата, 1986.

150. Пересветов Н.Н. Деловые игры как средство активного воспитательного воздействия. В сб: «Формирование мировоз- зренческой культуры будущего педагога». - Уральск, УПИ, 1989 , стр.78- 82.

151. Пересветов Н.Н. Каждому учителю физкультурную грамотность. Научно-методический журнал «Устаз», Уральск, ИУУ, 1998, № 1, стр. 61 - 67.

152. Пересветов Н.Н. Нетрадиционный подход при реализации физического воспитания студентов. В сб.: Материалы 2-ой научно-практической конференции профессорскопреподавательского состава, посвященных Году народного единства и национальной истории. - Уральск, «Центр стардартизации, метрологии и сертификации», 1998, стр. $71-75$.

153. Пересветов Н.Н. К здоровью - через туризм. Из опыта работы Зап.-Каз. Областного центра туризма и экологии. Методические рекомендации для педагогов дополнительного образования. - Уральск: Полиграфсервис, 2000.

154. Пересветов Н.Н. Нетрадиционные формы туризма и путешествий: проблемы и решения. Научно-методический журнал «Устаз», Уральск, 2000, № 1, стр. 20 - 27.

155. Пересветов Н.Н. Туризм Западного Казахстана: реалии и перспективы. В сб.: Материалы Международной научнопрактической конференции «10 лет суверенному Казахстану: ретроспективы, анализ и перспективы». - Актобе, 2001, стр. $184-191$.

156. Пересветов Н.Н. Евразийская культура личности состояние и перспективы формирования. Там же, стр. $269-$ 275.

157. Пересветов Н.Н. Исследование мотивации и оценка деятельности экспедиции «Жайык-Урал» (по итогам пяти лет) . В сб.: Материалы Международной научно-практической конференции «Социально-экономические приоритеты развития СНГ». - Алматы, 2003, стр.183 - 185.

158. Пересветов Н.Н. Экспедиции «По следам В. Правдухина»: взгляд изнутри. В сб.: Историко культурные, экологические экспедиции по р. Урал: возможности и перспективы туризма Западного Казахстана. Межрегиональная научно- 
практическая конференция 22 - 23 апреля 2003. - Уральск, 2003, стр. $-70-81$.

159. Пересветов Н.Н. «Год Казахстана в России» в деятельности экспедиции по р. Урал. В сб: Проблемы современного социально-экономического развития общества. Тезисы докладов научно-практической конференции. - Уральск, 2004, стр. $84-89$.

160. Пересветов Н.Н. Валеология. Избранные лекции. Учебно-методическое пособие для студентов. - Уральск, 2004.

161. Пересветов Н.Н. и др. Паломничество: пути развития туризма в Западном Казахстане. В сб: Актуальные проблемы экономики Западно-Казахстанского региона. Материалы областной научно-практической конференции ППС и магистрантов, посвященной памяти профессора Б.Г. Гумарова. Уральск, ЗКГУ, 2005, стр. $57-62$.

162. Пересветов Н.Н. Воспитательный и научный потенциал историко-культурных, экологических экспедиций по p. Урал (к 10-летнему юбилею). - Уральск. Полиграфсервис, 2006.

163. Пересветов Н.Н. Обеспечение жизнедеятельности: от теории к практике. Избранные лекции. - Уральск, Зап.- Каз ЦНТИ, 2006.

164. Пересветов Н.Н. Воспитательная работа: опыт, теория, методика. Учебно-методическое пособие для студентов. - Уральск, Западно-Казахстанский ЦНТИ, 2007.

165. Пересветов Н.Н. и др. Внешкольные воспитательнообразовательные учреждения спортивного профиля. Учебнометодическое пособие. - Уральск, ЗКФ АО «НЦНТИ», 2008.

166. Пересветов Н.Н. Нравственное воспитание молодежи средствами двигательной деятельности. В сб.: Материалы Международной научно-практической конференции «Актуальные проблемы физического воспитания и пути их решения». - Уральск, ЗКГУ, 2008, стр. $31-40$.

167. Пересветов Н.Н Воспитательный потенциал совре- менного олимпизма. Размышление на тему. // Пульс города, 2009, №№ 4 и 5, стр. 12.

168. Пересветов Н.Н. Итоги Олимпиады - 2008 и перспективы улучшения деятельности тренерского состава. В сб: «Вестник Западно-Казахстанской гуманитарной академии. Научный журнал. - Уральск, 2009, стр. 64 - 68.

169. Пересветов Н.Н. Профессионально-прикладная физическая подготовка в экстремальных видах спорта. (На примере деятельности СДЮСШ по авиационно-техническим видам). В сб: «Вестник Западно-Казахстанской гуманитарной академии». Научный журнал. - Уральск, 2009, стр. 108 - 115.

170. Пересветов Н.Н. и др. Нетрадиционные формы и методы проведения практических занятий в вузе. - Уральск, ЗКФ АО «ЦНТИ», 2009.

171. Пересветов Н.Н. Азиада - 2011: процесс подготовки и воспитательный потенциал Евразийской культуры. В сб: «Вестник Западно-Казахстанской гуманитарной академии. Научный журнал. - Уральск, 2010, стр. 137 - 142.

172. Пересветов Н.Н. и др. Физкультурники и спортсмены Казахстана в боях за Родину в годы Великой отечественной войны. В сб: «Материалы Международной научнопрактической конференции «Современные тенденции развития физкультурного образования», посвященной У11-м Азиатским играм». - Уральск, ЗКГУ им. М. Утемисова, 2010, стр. $6-10$.

173. Пересветов Н.Н. Воспитательный потенциал олимпийского движения. В сб: «Вестник Западно-Казахстанского гуманитарной академии. Научный журнал. - Уральск, 2010, стр. $186-192$.

174. Пересветов Н.Н. О содержании профессиональной подготовки специалистов - «Менеджеров туризма». В сб: «Вестник Западно-Казахстанской гуманитарной академии» Научный журнал. - Уральск, 2011, стр. 15 - 21.

175. Пересветов Н.Н. К вопросу о содержании учебнометодического пособия «История физической культуры и 
спорта Республики Казахстан» С древнейших времен до наших дней. В сб. Вестник Западно-Казахстанской гуманитарной академии. Научный журнал. - Уральск, 2013, стр. 52 -55 .

176. Пересветов Н.Н. Спортсмены Западного Казахстана в боях за Родину в годы ВОВ (1941 - 1945 гг.). В сб: Материалы научно-практической конференции «Вклад Западного Казахстана в Победу в Великой Отечественной войне». - Орал , ЗКГУ, 2013, стр.31 - 38.

177. Пересветов Н.Н. ХХ11-е Зимние Олимпийские игры и проблемы повышения профессиональной компетенции специалистов. В сб. Вестник Западно-Казахстанской гуманитарной академии. Научный журнал. - Уральск, 2014, стр. 20 - 31.

178. Пересветов Н.Н. и др. Аспекты физкультурноспортивного краеведения. т. 1. Учебно-методическое пособие. Под редакц. профессора Ж.Т. Ерназарова. - Уральск, 2015.

179. Пересветов Н.Н. Аспекты физкультурно-спортивного краеведения. т. 2. Учебно-методическое пособие. Под редакц. профессора Ж.Т. Ерназарова. - Уральск, 2016.

180. Пересветов Н.Н. Аспекты физкультурно-спортивного краеведения. т. 3. Учебно-методическое пособие Под редакцией профессора Ф.И. Собянина. - Уральск, 2018.

181. Пересветов Н.Н. Пропаганда Евразийства в действиях экспедиции «Жайык - Урал». В кн: Урал - река жизни. Уральск, Полиграфсервис, 2017, стр. 34 - 35.

182. Пономарев Н.И. Возникновение и первоначальное развитие физического воспитания. - М.: ФиС, 1970.

183. Пономарев Н.И. Физическая культура как элемент культуры общества и человека. - С-Пб.: ГАФК им. П.Ф. Лесгафта, 1996.

184. Приходько В.В. Непрофессиональное физкультурное образование. - М.: ФиС, 1991.

185. Прохорова М.В. и др. Педагогика физической культуры. Учебник. -С-Пб.ГУФК,1998. 186. Прохорова М.В. и др. Педагогика физической культуры.
Учебник. - М.: Путь, 2006.

188. Прохорова М.В. и др. Воспитательный потенциал греко-римской борьбы. Учебное пособие. - СПб, 1998.

189. Прохорова М.В. Борьба - цель, смысл и стихия жизни. Под общей редакцией В.П. Галенко. - СПб.: СПбГУЭФ, 2002.

190. Рекорды, события, люди. Редактор - В.П. Бурич. - М.: ФиС, 1969.

191. Рыканов В.А. Экологическое воспитание в общественных клубах краеведов. Методич. рекомендации. - Л., 1990, стр. 2 - 3 .

192. Рыканов В.А. Экологическое воспитание краеведовлюбителей. Дисс. канд. пед. наук. - СПб,: СПбГАК, 1994.

193. Рысбеков Т.З. и др. История Западно-Казахстанской области. Учебное пособие. - Уральск, 2003.

194. Рысбеков Т.3. Диалог с историей. - Уральск, ЗКГУ, 2007.

195. Рысбеков Т.3. Этюды истории родного края. - Уральск, ЗКГУ, 2007.

196. Рысбеков Т.3. и др. История Западно-Казахстанской области. Кчебное пособие для учащихся. - Уральск, 2015.

197. Савин В.И. Современное олимпийское движение. М.: Знание, 1970.

198. Садвакасова 3.Т.Новейшая история Казахстана. Учебное пособие. - Алматы, КНУ им. Аль-Фараби, 2009.

199. Салов В.Ю. Теоретические и методические основы формирования здорового образа жизни средствами физической культуры: Автореф. дис. доктора пед. наук.- СПб, 2001.

200. Свиридова А.Ю. Использование краеведческого материала в начальной школе на уроках и во внеурочное время. В кн: Опыт и проблемы социализации воспитанников детского дома средствами физкультурно-спортивной и туристско-краеведческой деятельности: материалы опытноэкспериментальной работы. Учебное пособие. - Москва, Воронеж, 2013, стр. $142-149$.

201. Сдыков М.Н. История населения Западного Казахста- 
на. - Алматы, 2004.

202. Сдыков М.Н. Средневековые города Западного Казахстана в письменных и материальных источниках. Ежегодник. Вопросы истории и археологии Западного Казахстана. Вып. №3. - Уральск, Полиграфсервис, 2016, стр.148; 2011.

203. Седьмые азиатские игры (Алматы - Астана). - Астана,

204. Соболев П.А. Международные связи советских спортсменов. -М., Знание, 1961.

205. Собянин Ф.И. Профессиональная подготовка учителя физической культуры на основе культурологического подхода. Автореф. дис. доктора пед. наук. - СПб, 2002.

206. Советская система физического воспитания. Гл. редактор Г.И. Кукушкин, - М.: ФиС, 1975.

207. Смирнов Д.В. и др. Концепция воспитательной деятельности общеобразовательного учреждения «Духовнонравственное воспитание обучающихся средствами школьных традиций». В сб. Вестник академии детско-юношеского туризма и краеведения. Научно-методический журнал. №1. - М., 2013, стр. 34 - 54.

208. Спорт в школе. Методическое пособие для спортивных секций коллективов физической культуры школ. Редакц. коллегия: С.С. Грошенков и др. - М.: ФиС, 1959.

209. Спортивная атрибутика. - Изд. 2-ое, испр. (Сост. В. Кудряшов). - М.: ФиС, 1978.

210. Спортивный Казахстан. Энциклопедический справочник. Авторы-составители: О. Калымбетов и А. Кульназаров. - Алматы: Арыс, 2004.

211. Спорт и личность; Спортивный ежегодник. Вып. 4-й. (Составитель А. Нилин) - М.: Мол. Гвардия, 1980.

212. Спорт и личность: Спортивный ежегодник. Вып.8-й. (Сост. В. Петраков, Е. Шаваловский). - М.: Мол. Гвардия, 1985.

213. Столбов В.В. История и организация физической культуры и спорта. - М.: Просвещение, 1982.
214. Столбов В.В. и др. История физической культуры и спорта. (Под ред. В.В.Столбова). - М.: ФиС, 2000.

215. Столбов В.В. и др. История физической культуры. Учебник. Под редакцией профессора В.В. Столбова. 3-е издание. - М.: ФиС, 2001.

216. Строев К.Ф. Краеведение. 2-ое дополн. - М., Просвещение. 1974.

217. Суетин А.Л. Учебники жизни Николая Пересветова./ Шанырак, 2018, №8, стр.16-18.

218. Сулейменов С.Х. и др Ардагер агалар. - Орал, Полиграфсервис, 2015.

219. Суровая драма народа: Ученые и публицисты о природе сталинизма. (Составитель - Сенокосов Ю.П.). - М.: Политиздат, 1989.

220. Таникеев М. Спорт как средство интернационального воспитания молодежи. В сб.: Философско-социологические исследования физической культуры и спорта (ежегодник) Выпуск первый. - М.: Советский спорт, 1988, стр. 141-151.

217. Туристические маршруты Казахстана. Рецензенты: Е.С. Никитинский и др. - Астана, 2002.

218. У Победы женское лицо. Сборник воспоминаний о боях-пожарищах, о друзьях-товарищах, о нелегкой жизни и работе в тылу. Автор-составитель Е.М. Купиева. - Уральск, Диалог, 1995.

219. Урок дает история. (Составитель А.А. Ильин). Под общей редакцией академиков В.Г. Афанасьева, Г.Л. Смирнова. - М.: Политиздат, 1989.

220. ФинаровД.П. и др. Комплексное краеведение. - СПб., Образование, 1995.

221. Фирсов 3.П. Советские спортсмены в боях за Родину. Материалы к лекциям и беседам - М.: Знание, 1970.

222. Фомин $\mathrm{B}$. Туристско-краеведческая экспедиция как форма экологического воспитания старшеклассников. Автореф.канд. пед. диссерт. - М.: 1997.

223. Фомин В и др. Туристско-экологическая экспедиция, 
как форма экологического воспитания учащихся. - Уральск, Полиграфсервис, 2000.

224. Фомин В.Патриотизм начинается со знания родного края. В сб:»Инновационные подходы втуристскокраеведческой деятельности системы детской-юношеского и молодежного туризма: проблемы и решения. Краснодар, 2013, стр. 172.

225. Хавин Б. 500 вопросов и ответов об Олимпийских играх. - М.: ФиС, 1971.

226. Хавин Б Все об олимпийских играх. - 2-ое изд., доп. - М.: ФиС, 1979.

227. Хрестоматия по физической культуре. Учебное пособие под оедакцией Ю.Курамшина- С-Пб.: ГАФК им. П.Ф. Лесгафта, 2001.

228. Хрипач Г.Н. Эффективный бодибилдинг. Серия «Красивое тело». - С-Пб.: Питер, 2007.

229. Шабаренина Т. О чем рассказал Урал.Уральск, Полиграфсервис, 2003.

230. Шаповалов С.А. Записки учителя физкультуры. - М.: ФиС, 1982.

231. Шаталов В.Ф.Организационные основы эспериментальных исследований (Методические рекомендации). В кн: Эксперимент в школьной практике. Часть 2-ая. - М., Творческая педагогика, 1991.

232. Шанин Ю. Герои античных стадионов. - М.; ФиС, 1971.

233. Шевченко В.Н. Всем классом на старт (Из опыта работы учителя). - Уральск, Обл. ИУУ, 1989.

234. Шевченко В.Н. Методика организации массовых спортивных соревнований школьников. г. Уральска, Обл. ИУУ, 2003.

235. Шевченко В.Н. Физическая культура в школах Уральска: проблемы и перспективы. - Уральск, Обл. ИУУ, 2005.

236. Шляпентох В.Э. Как сегодня изучают завтра. (Современные методы социологического прогнозирования). - М.:
Сов. Россия, 1975.

237. Энциклопедия по физической культуре и спорту. В 3-х том. (Гл. редактор - Г.И. Кукукшкин). - М., ФиС, 1968

238. Щербанов Н.М. «Поехал я в Уральск...» А.С. Пушкин и Приуралье. - Уральск, ТОО Оптима, 2003.

239. Щербанов Н.М. Уральск литературный. - Уральск, Полиграфсервис, 2008.

240. Эксперимент в школьной практике. Редактор- Р.Г. Чуракова. Часть 1-ая. - М., 1991.

242. Эксперимент в школьной практике. Редактор - Р.Г. Чуракова. Часть 2-ая. - М., 1991.

243. Юсин А.А. Век спортивный. - М.: ФиС, 1971.

244. Юрмин Ю.А. От «А» до «Я» по стране спорта. Какая ты, Спортландия? - М.: ФиС, 1970.

245. Ягнинский А.М. Алиби Джангильдин-казахский Марко Поло. // Сотпак-Тропинка, - Уральск, Обл. ЦДЮТиК,1999, №№ $2,3,4,5$.

246. Ягнинский А.М. Чокан Валиханов - первый ученый казахского народа. В сб: Вопросы истории и археологии Западного Казахстана. - Уральск, 2008, №2, стр. 145 - 158.

247. Я познаю мир: Спорт: Детская энциклопедия (В.И. Малов) Под общ. редакцией Е.М. Ивановой. - М., «Издательство Астрель», 2002. 
Западно-Казахстанский инновационнотехнологический университет

\section{Методика физического воспитания учащихся в специальных школах:}

Учебное пособие для студентов и магистрантов педвузов, университетов.

Авторы-составители:

\section{Пересветов Н.Н., Кузнецова А.Н.}

Литературный редактор: Кузнецова А.Н.

Бумага офсет. Формат 64×92/16.

Подписано в печать 15.02.2021. Объем 15 усл.п.л. Тираж 100 экз.

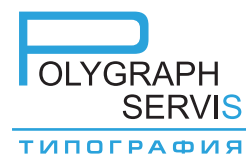

Отпечатано в типографии ТОО «Полиграфсервис», г.Уральск, ул. Л.Толстого, 27/6. Тел.факс: 8 (7112) 50-51-46, 51-41-99 